\title{
WestVirginiaUniversity
}

THE RESEARCH REPOSITORY @ WVU

Graduate Theses, Dissertations, and Problem Reports

2006

\section{Three essays on banks' relative efficiency}

Jorge Guillen

West Virginia University

Follow this and additional works at: https://researchrepository.wvu.edu/etd

\section{Recommended Citation}

Guillen, Jorge, "Three essays on banks' relative efficiency" (2006). Graduate Theses, Dissertations, and Problem Reports. 2438.

https://researchrepository.wvu.edu/etd/2438

This Dissertation is protected by copyright and/or related rights. It has been brought to you by the The Research Repository @ WVU with permission from the rights-holder(s). You are free to use this Dissertation in any way that is permitted by the copyright and related rights legislation that applies to your use. For other uses you must obtain permission from the rights-holder(s) directly, unless additional rights are indicated by a Creative Commons license in the record and/ or on the work itself. This Dissertation has been accepted for inclusion in WVU Graduate Theses, Dissertations, and Problem Reports collection by an authorized administrator of The Research Repository @ WVU.

For more information, please contact researchrepository@mail.wvu.edu. 


\title{
Three Essays on Banks' Relative Efficiency
}

\author{
Jorge Guillén
}

\begin{abstract}
Dissertation Submitted to the
College of Business and Economics at

West Virginia University

in partial fulfillment of the requirements for the degree of
\end{abstract}

Doctor of Philosophy

In

Economics

\author{
Santiago Pinto, Ph.D., Chair \\ Stratford Douglas, Ph.D. \\ Alexei Egorov, Ph.D. \\ Ashok Abbott, Ph.D. \\ Arabinda Basistha, Ph.D.
}

Department of Economics

Morgantown, West Virginia

2006

Keywords: Data Envelopment Analysis, Stochastic Frontier Analysis, Riegle Neal Act, Nonperforming Loans

Copyright 2006, Jorge Guillén 


\section{$\underline{\text { ABSTRACT }}$ \\ Three Essays on Banks' Relative Efficiency}

Jorge Guillén

Three separate studies are conducted regarding banks' relative efficiency. Previous to start with the development of the studies, we review the situation before and after the enactment of the Riegle Neal's. This act restricts banks from opening branches in another state. The Riegle Neal act ended up the era of state branching deregulation which started in 1970. A discussion between proponents and opponents of branching deregulation is presented. A debate between bank's efficiency and concentration before Riegle Neal is introduced in the chapter.

The first essay found in chapter 2, develops a theoretical model of spatial competition between banks. Two different scenarios are considered. The first one assumes that banks cannot open a branch or a subsidiary in another region. The second scenario assumes that there are no branching restrictions. We derive the Nash Equilibria and determine winners and losers in each case. Moreover, we study whether the incentives to open a branch are affected when the cost of performing long-distance transactions decreases, as evidenced in the banking sector. The model is able to explain who benefited from the branching restrictions implemented in the U.S. in 1927 and why this law was then eliminated in 1994.

Chapter 3 contains the second essay. It addresses the effect of banking and branching state deregulation on banks' efficiency. The Riegle Neal Act of 1994 concluded the process of state deregulation which started in 1970. In this paper we calculate an indicator of bank efficiency using Data Envelopment Analysis (DEA). The efficiency indicator is used as the primary input to analyze the effect state branch deregulation on bank's efficiency. In addition, a failure prediction model is carried out using these efficiency indicators. Size and regional allocation effects for banks are considered in the paper.

Chapter 4 contains the last of the three studies. We test the validity of different hypotheses commonly employed to explain the proportion of non-performing loans held by banks. Particular attention is devoted to establish the link between efficiency and the share of non-performing loans. Based on the results of causality tests, our empirical analysis suggests that the Moral Hazard, Bad Management, and Skimping Hypotheses can still explain the proportion of nonperforming loans for each bank size during the last ten years. The result complements the study of Berger and DeYoung (1997). 
To Katy and Sebastian 


\section{ACKNOWLEDGEMENTS}

I am greatly indebted to my advisor, Santiago Pinto and his patience and remarkably guidance during these four years in the $\mathrm{PhD}$ program. He just helped me turning my ideas into a dissertation. He always had some time to read carefully my papers and provide invaluable ideas and suggestions. He always gave me personal advises besides his guidance toward the completion of my doctoral degree.

I should express gratefulness to the remaining members of my dissertation committee, Stratford Douglas, Mehmet Tosun, Arabinda Basistha, Alexei Egorov and Ashok Abbott. I just really appreciate their help and time.

Many thanks go to my professor and colleagues in the Department of Economics. A special recognition goes to Ellis Heath for his help in the final edition of my dissertation.

My sincere gratitude to my parents, Alfredo and Adriana for tried their best raising me. My family's support alleviates the stress I have been through this period of time. I also thank to my brothers and sister for their support. My special recognition goes to my brother Carlos. He has been an important master piece in the completion of my education.

I would like to extend the thanks to my friends Robert La Porte and Trace Gale for their friendship. They make my stay in Morgantown very pleasant. I also appreciate the guidance of Cesar Fuentes, Javier Illescas and other Peruvian and Spanish Economists that encouraged me to finish my professional goals. I just can not list all of them at the same time but my sincere recognition to them.

Finally, I want to thank the most important person in my life: my wife Katy. I thank her for being very patient during these years. She helped me by spending many hours encouraging me to finish my goals. She amazingly completed two masters during our stay in United States and now she is giving me my first son: Sebastian Jorge. We have passed through some personal difficulties but besides that, we have been able to overcome everything together.

Any errors are the sole responsibility of the author. 


\section{Table of Contents}

ABSTRACT

ACKNOWLEDGEMENTS

Chapter 1: Introduction to the Three Essays on Bank's Relative Efficiency

1.1 Introduction

Chapter 2 :Review of the situation before and after the enactment Riegle Neal's

2.1 The History before Riegle Neal Act

2.2 Opponents and the Proponents of Branching

2.3 The attempts to avoid the restriction on branching

2.4 The path to the deregulation

2.5. The Riegle Neal Act of 1994

Chapter 3: Spatial Competition between Banks: A Theoretical Model

3.1. Introduction

3.2. Banking Deregulation: Brief Historical Review

3.3. The Model

Table 3.1 The Consumer Payoffs with branching restrictions

Table 3.2 Consumer Payoff in Scenario II without branching restrictions

Figure 3.1 Extensive form representation of the game.

3.4. The Model with Identical Costs

3.4.1. Scenario I: bank 1 operates in A and bank 2 operates in B

3.4.2. Scenario II: bank 1 opens a branch in region B

3.4.3. Comparing the results

Table 3.3 Summary of Results: $\mathrm{c} 1=\mathrm{c} 2=0$

3.5. The Model with Heterogeneous Operating Costs and Positive Set-up Costs

Table 3.4 Heterogeneous Variable Costs: $\mathrm{c} 2>\mathrm{c} 1=0, \beta>\mathrm{c} 2$

3.6. Conclusions

Chapter 4: Branch Deregulation in the US Banking System

4.1 Introduction

4.2 Situation Before and after 1994 Act

\begin{tabular}{ll} 
4.3.1 Methodology. & 37 \\
\hline
\end{tabular}

$\begin{array}{ll}\text { 4.3.2 Data description } & 39\end{array}$

4.3.3 Data Envelopment Analysis estimation results $\quad 40$

4.4 Empirical Model $\quad 42$

4.4.1 Determinants of Bank Efficiency $\quad 42$

4.4.2 Bank Bankruptcy Analysis 46

4.5. Conclusions $\quad 51$

Chapter 5: Lending Practice Outcomes of Large and Small Banks 53

5.1. Introduction 54

5.2 The four Hypothesis about Problem Loans and Efficiency 55

5.3 Review of Bank Lending Practices by bank's size $\quad 57$

$\begin{array}{ll}5.4 \text { Overview of the Banking during 1984-2004 } & 58\end{array}$

$\begin{array}{ll}\text { 5.5. Estimation of the Efficiency } & 60\end{array}$

$\begin{array}{ll}\text { 5.6. Panel Model } & 63\end{array}$

5.7. Results 65

$\begin{array}{ll}5.8 \text { Conclusions } & 67\end{array}$

$\begin{array}{ll}\text { Chapter 6: Summary and Concluding Remarks } & 68\end{array}$

$\begin{array}{ll}6.1 \text { Summary } & 68\end{array}$

6.2 Concluding Remarks $\quad 69$

Appendix 
Figures and Tables

Table 4.1: DEA Indicators Summary Results $\quad 72$

Table 4.2: Intrastate Branching Deregulation by State 73

4.3: Distribution of states by the assigned four regions 74

Table 4.4: Determinants of DEA scores: Pool Estimations 75

Table 4.5: Determinants of Banks Failure: Three year Logit Model 76

Table 4.6: Marginal Effects of the Logit Model.

Figure 4.1: A graphical explanation of the DEA $\quad 78$

Figure 4.2: DEA by Quartiles $\quad 78$

Figure 4.3: Average DEA scores by states (1984) 79

Figure 4.4 :Average DEA scores by states (1997) 80

Figure 4.5: DEA for Regions 81

Figure 4.6: Intrastate Branching allowed by merger and acquisitions $\quad 82$

Figure 4.7: Banks by Regions with assets below US100 Mill. 83

Figure 4.8: Number of Failing Banks by Region $\quad 83$

Figure 4.9: Number of Failing Banks by Size 84

Table 4.7: Definitions and descriptive statistics for the variables employed in the Pool and Logit Model

(for the whole period 1984-1997).

Figure 5.1: Evolutions of Shares of NPL, Capital and Efficiency 86

Figure 5.2: Size Distribution of Banks in 1990 and $2000 \quad 87$

Table 5.1: Cost Efficiency Scores.

Table 5.2: Granger Causality: NPL/LOAN does not cause Efficiency 89

Table 5.3: Granger Causality: Scores of Efficiency that does not cause NPL/LOAN 92

Table 5.4: Granger Causality: Efficiency scores above average that does not cause NPL/LOAN 95

Table 5.5: Granger Causality: CAPITAL/ASSET does not cause NPL/LOAN 98

Table 5.6: Summary of the Four Hypotheses by size and period of time 101

Table 5.7: Definitions and descriptive statistics for the variables employed in Granger Causality Test

(for the whole period 1985-2005). $\quad 102$

References 103 


\section{Chapter 1}

Introduction to the Three Essays on Bank's Relative Efficiency 


\subsection{Introduction}

This dissertation presents three essays on banks' relative efficiency. We calculate two different methodologies to obtain efficiency indicators. We use these efficiency indicators as primary inputs to analyze different aspects of the banking system. Branch Regulation in the US banking system is the first issue in this study. In the last chapter, hypothesis about intertemporal relationships between shares of capital, nonperforming loans and efficiency are discussed with a new methodology to measure efficiency. Here, we include size effects and two time periods.

The second chapter presents a review of the situation before and after the enactment of the Riegle Neal Act of 1994. The act released the restriction to open branches. The chapter discusses two different points of view regarding branching restrictions. We also describe some attempts to avoid the restriction to open branches. The chapter is an introduction to the three essays discussed later.

The third chapter develops a theoretical model of bank competition. We develop two different scenarios in the model. The scenarios vary depending on whether a bank is allowed to open a branch in another state or not. The main results of the model discuss some of the principal issues presented in the previous and next chapter. The model developed in this chapter is able to explain some important factors that permitted the enactment of the Riegle Neal Act of 1994.

The fourth chapter presents an empirical analysis of the effects of banking deregulation. The chapter is a complement to the third chapter. In 1994, as we mentioned, branching restrictions were eliminated for all states in the US. However, many states started to relax branching restrictions during the 80 's. The focus of the chapter is to determine whether this deregulation process affected banks' efficiency. In addition we run a logit model to evaluate if deregulation affected bank's failure. 
The fifth chapter presents an analysis of the intertemporal relationships between shares of capital, nonperforming loans and efficiency. These intertemporal relationships are evaluated by testing four hypotheses about Bad Management, Skimping, Bad Luck and Moral Hazard. We use a different approach to measure efficiency indicators. The methodology is called Cost Efficiency that contrasts with Data Envelopment Analysis technique described in the fourth chapter. The analysis of the intertemporal relationships between shares of capital, nonperforming loans and efficiency complements the seminal paper by Berger and DeYoung (1997). 


\section{Chapter 2}

Review of the situation before and after the enactment Riegle Neal's 


\subsection{The History before Riegle Neal Act}

The discussion about allowing a bank to open a branch or not can be trace back on 1864 , when Congress passed the first major national banking legislation in the United States. The National Banking Act of 1864 (the "1864 Act") provided the US a uniform system of currency and established a market for government bonds to finance the Civil War. The passage of the 1864 Act provided banks the alternative to choose between federal or state chartering legal scheme.

In 1865 , Congress placed a ten percent tax on state bank notes. The purpose of this tax was to disincentive the use of these notes in order to promote the circulation of the new established national currency. Some banks could decide to be under federal laws instead in order to get the maximum benefits from this legal scheme. The bank duality to choose under federal or state legal system was applied in the McFadden Act (1927). This act was enacted in 1927. The Act gives national banks the power to establish branch banking offices, but if and only if a state law permits a state chartered bank to do the same action.

Therefore many National banks started to convert their federal charters into state charters in order to take advantage of favorable state branching laws. This imbalance put in danger the existence of the entire national banking system.

The McFadden Act, to avoid this problem, was considered and refined during four consecutive sessions of Congress. In 1933, Congress amended the Act. The main changes will be discussed in this chapter. 


\subsection{Opponents and the Proponents of Branching}

There were proponents and opponents of the branching restriction. The main discussions are given in Senzel (1992) paper.

\section{A.Portfolio Diversification versus. Development of the Community}

Opponents of branch banking argue that branch banks would not be able to serve the needs of their host communities. These people believe that banking services must be provided by small local banks because the individuals here are familiar with the needs of a particular community, while branch banks would be run by business man unfamiliar with these needs.

Branching opponents also say that local banks should be able to meet all the credit needs. The community could grow because the local bank reinvests in the surrounding area. The proponents of the branching, however, stressed the necessity of a diversification of portfolio. They claim that efficient redistribution of resources is possible by branching. This situation happens when it is possible to transfer loanable funds from areas of low demand to areas with a higher level of need. These transfers were characterized by opponents as draining money away from rural communities to speculative investments which are far away from the community.

\section{B. The Banking Efficiency Discussion}

The most indisputable argument in the branch banking debate was that branch banking would increase or not the efficiency. The branch proponents consider that by increasing the number of firms, then banks could participate in multiple markets and offer services to specific market with less cost.

The opponents of branching believed that branch banking was based on the theory of market concentration. These people say that concentration of resources would reduce competition. Opponents of branching also argued that branch banking would gradually eliminate competitors because large banks open branches in small towns and take small banks away from the 
community. The situation is considered by opponents as a possible formation of regional monopolies.

\subsection{The attempts to avoid the restriction on branching ${ }^{1}$}

\section{A. Bank holding companies}

In order to overcome the restrictions on branching imposed by McFadden Act(1927), banks began forming bank holding companies (BHCs) which enabled banks to affiliate with other banks outside their limited branching territory. The BHC structure was not like allowed banking companies to expand geographically and enter to new markets. The rapid growth of BHCs made the Congress became concerned about the possible bank concentration. The final outcome of this concern was the imposition of the Bank Holding Company Act of 1956 (BHCA) which regulate the geographic expansion, concentration, and affiliation of BHCs. The Douglas Amendment (1956) prohibited to the BHCs the acquisition of an out of state banking subsidiary unless authorized by the law of the state. The BHC, in general cannot acquire or retain "direct or indirect ownership or control of any voting shares of any company which is not a bank." BHCs are, however, allowed to acquire nonbank subsidiaries.

\section{B. Another attempts to avoid branching}

Faced with the restrictions on branching under the McFadden Act (1927), banks have devised several ways to serve a greater geographic area without "branching" and violating branch banking laws.

1. Armored car services. The most typical case of this violation was made by First National Bank. This bank was sued and The Supreme Court found illegal the attempt to collect cash

\footnotetext{
${ }^{1}$ Tart (1995) provide a very detailed review of these attempts.
} 
and checks in a car service. The bank also attempted to establish "secured receptacles" where customers could leave deposits to be picked up by the armored car.

Courts decided that an armored car service constitutes a branch whenever the bank or affiliate owns or operates the service. In contrast Bay National Bank and Trust Co., was allowed to upheld the operation of an armored car service owned by a third party. This ambiguity of verdicts comes from the vagueness of definition of branch in the McFadden Act and Douglas Amendment which is pointed out by Tart (1995).

2. Loan production offices. Another early attempt for banks to expand geographically their frontiers of business was with the establishment of loan production offices (LPOs).LPO was not under the definition of branching that any law discussed permit and even The Code of Federal Regulations.

There was a particular case in 1980 where the Court of Appeals for the District of Columbia, in reversing a district court decision, upheld the Comptroller's decision that LPOs did not constitute branches. This court applied the doctrine of "laches"2. This is verdict shows another vagueness in the law.

3. Automatic teller machines (ATMs). Although accepted today, ATMs were not allowed throughout the 1970s and the beginning of the 1980s. The Independent Bankers were sued and found by the Court of Appeals for the District of Columbia that its ATMs perform the three functions of branching. ${ }^{3}$.

The Court of Appeals for the Second Circuit decided in 1985 that use of an ATM did not constitute "branching" even in case the bank does not own or rent them. This new regulation

\footnotetext{
${ }^{2}$ The legal doctrine that a legal right or claim will not be enforced or allowed if a long delay in asserting the right or claim has prejudiced the adverse party (hurt the opponent) as a sort of "legal ambush".

${ }^{3}$ The three definitions are: an entity is considered branch if it receives deposits, pays checks, or lends money. They can be found in section 36(f) of the McFadden Act (1927).
} 
pass through because of the increasing demand for ATMs and the necessity to be updated according with the new technology

4. Crisis and the expansion of Holding Companies. Loan crisis of the 1980 s produced that institutions began to fail in big numbers. Therefore Congress passed the Garn-St. Germain Act $(1982)^{4}$ allowing emergency interstate acquisition of failing thrift institutions regardless of state anti-branching laws. In 1989, acquisition was expanded through the Financial Institutions Reform, Recovery and Enforcement Act (FIRREA). The latter act states an authorization bank holding company (BHCs) to acquire any savings association.

5. Reciprocal Regional Agreements. Regional bank centers emerged when competition and the necessity to expand geographical frontiers increased. The first reciprocal regional arrangement involved the New England states: Massachusetts, Connecticut, Vermont, New Hampshire, Maine, and Rhode Island These states worked under the restrictions of (1) "regional restrictions" which is requiring the expanding bank to be located in a specific geographic region, and (2) "reciprocity restrictions" requiring to branch in the state where is also allowed to branch reciprocally. These state laws utilize features such as prohibiting de novo entry, establishing deposit location rules, establishing state deposit caps, and any other requirement the state feels is necessary to protect the interests of the regional state.

\subsection{The path to the deregulation ${ }^{5}$}

A foreign bank was able to branch in US during 1970, but after several complains by the side of domestic banks, the Congress passed out the International Banking Act in 1978. In this acts foreign banks will be treated in the same way as the US banks. I think that this restriction

\footnotetext{
${ }^{4}$ St Germain was an act to revitalize the housing industry by strengthening the financial stability of home mortgage lending institutions and ensuring the availability of home mortgage loans.

FIRREA act restructured the savings and loan association regulatory system; enacted in response to the savings and loan crisis of the 1980s.

${ }^{5}$ Patric Mulloy (1995) provided an explanation of the path to deregulation.
} 
disincentives the foreign investment even though the national investment in the country is significant.

In 1985, there was a discussion about the regional compacts agreements. Chairman of the Federal Reserve Board Paul Volcker discuss the possibility to wait some years and see what happen in the regional compact agreements and then try to apply this to the rest of the nation. Volcker really wanted to observe the possibility of a concentration in the bank system. He also suggested restriction in the acquisition of banks. Volcker proposed to impose limits in the proportion of assets of acquiring banks and forbid to the 25 top banks in US to merge. This idea that Volcker expressed is a precedent in the formulation of the Riegle Neal Act of 1994.

At 1983, three U.S. commercial banks were among the world's top twenty in asset size; by 1988 no U.S. bank was ranked among the world's top twenty. In addition in the ranking of the world's top 50 banks in market capitalizations for 1988, only two were U.S. banks. The necessity of the elimination the branching restriction emerged with big necessity.

\subsection{The Riegle Neal Act of 1994}

President Clinton signed the bill into law on September 29, 1995. Thomas LaBreque, the Chief Executive Officer of Chase Manhattan Bank, said: "This law will change that and enable global banks such as Chase to compete more successfully around the world as well."

\section{Major Provisions of the Riegle-Neal Bill}

\section{A. Interstate Banking}

Interstate banking refers to the ability of a bank holding company to own and operate banks in more than one state. Then Douglas amendment (1956) was not longer valid now.

Interstate expansion by bank holding companies is subject to concentration limits. The Federal Reserve Board is prohibited from approving an interstate acquisition that would result in the holding company controlling more than 30 percent of the deposits held by insured depository 
institutions in a particular state, unless the host state eliminates the limitations entirely or has a lower concentration restriction. The Federal Reserve would also be prohibited from approving an acquisition if, as a result, the bank holding company would control more than 10 percent of the total amount of deposits of insured depository institutions in the United States.

\section{B. Interstate Branching}

Interstate branching is the equivalent to say that a bank can operate branches in more than one state. As we discussed above some years before this bill passed out The New England zone had the opportunity to form zones of agreements and the banks at this zone could branch within this area.. Similarly, an existing network of bank holding company subsidiary banks could be consolidated into branches of a single bank. Now a bank can open a branch in a state without creating a new bank or BHC.

To be eligible to merge interstate each bank involved in the transaction must be adequately capitalized and managed when the application is filed. Thus, a bank holding company with some distressed subsidiaries must recapitalize them before they can be merged. The resulting bank must also be adequately capitalized.

Concentration limits, the same as those for interstate banking, apply to branching. However the concentration limits, do not apply to any mergers of banks that are already affiliated. This would allow a bank holding company to consolidate its existing network of subsidiary banks into one bank. 


\section{Chapter 3}

\section{Spatial Competition between Banks: A Theoretical Model}




\subsection{Introduction}

The U.S. banking industry has undergone in the last thirty years through a long process of deregulation. This paper focuses on one aspect of such process: the deregulation of bank branching restrictions. In 1927, the McFadden Act introduced federal restrictions on interstate banking. This legislation prevented U.S. commercial banks from establishing branches in other states, unless explicitly allowed by state law. Since the early 1980s, many states allowed different forms of interstate banking through the subscription of reciprocal regional agreements. ${ }^{6}$ Finally, in 1994, another federal law, the Riegle-Neal Interstate Banking and Branching Efficiency Act (1994), permitted as of June 1997 nationwide branch banking. In this paper we develop a theoretical model that attempts to explain the rationale behind the law that originally prohibited bank branching, and the subsequent decision to eliminate the restrictions. The model synthesizes the discussion between proponents and opponents of bank branching restrictions in a spatial competition model. Our goal is to examine the effectiveness of this kind regulation in a context where banks have the alternative to target customers from a single location.

Even though the interstate bank branching restriction prevented banks from opening offices across states, it could not stop local consumers from operating with banks located elsewhere if the opportunities offered by these banks were attractive enough. However, banking transactions with non-residents are necessarily performed at higher costs. The paper exploits the idea that even though local banks were protected from direct competition, distant banks were still able to capture some of the local customers if the cost of performing long distance transactions was small enough.

Since the McFadden Act of 1927, dramatic changes have been taking place in the banking industry. Improvements in transportation, communication, and computer technology have

\footnotetext{
${ }^{6}$ See, for example, Tart (1995).
} 
remarkably changed the way the banking industry operates. The advances generated, among other things, a significant decline in the cost of performing long-distance transactions. As a result, banks may no longer find it desirable to open branches elsewhere to serve distant customers, so any law that prevents banks from doing so would be obsolete and irrelevant. Our model permits us to evaluate precisely how the technological changes evidenced in the banking sector affected banks' incentives to open branches in other regions. ${ }^{7}$

One of the conclusions in our paper is consistent with the idea that some regulations are simply eliminated because they became obsolete and outdated given the technological state of affairs. The removal of such restrictions would not have a real effect and, in fact, nobody will oppose it. It would just set the rules in accordance with economic reality. ${ }^{8}$

The question addressed in this paper is not new. It has previously been considered by a number of different authors. For example, our work is closely related to Petersen and Rajan (2002), who find that the distance between small firms and their lenders has systematically increased over the period 1973 to 1993 . They claim that such effect can be attributed to technological improvements in the banking industry: greater use of computers and communication equipments. As a result, they argue, the incentives to preserve geographical restrictions on bank branching are greatly diminished.

Kane (1996) follows a public-choice approach to explain the changes in rules and regulations. The lobbying pressure of three interest groups, small to medium banks, large banks, and consumers, ultimately shape the regulatory environment. Kane (1996) claims that restrictions were not removed until technology improvements had changed the "preexisting

\footnotetext{
${ }^{7}$ Senzel (1992) and Rollinger (1996) among others, provide evidence supporting the idea that technological advances made geographical restrictions irrelevant. For instance, improvements in the communication technology have made it possible for banks to use electronic methods to transfer funds. These systems became available to bank customers as customer bank communication terminals (CBCT), automated teller machines (ATM), point of sale terminals (POS), etc.

${ }^{8}$ We realize that the argument in our paper is rather extreme. Our goal is, however, to point out that the real effects in the banking industry were mostly driven by technological changes and the deregulation process was more a consequence rather than an effect of the changes.
} 
balance of lobbying pressure." Calomiris and Ramirez (2004) also employ an interest-group explanation. Instead of focusing on the incentives of small banks to lobby for protection, they claim that certain types of borrowers would actually benefit from the entry barriers. In particular, branching restrictions create strategic advantages for those who own immobile factors of production. Kroszner and Strahan (1999) find evidence that interest group factors largely explain the timing of state-level deregulation of bank branching restrictions. They also identify communications and information processing technology as important factors driving the process of barrier relaxation. They suggest that as a result of the technological advances, large banks gained strength as an interest group in detriment of small banks that have traditionally benefited from the branching restrictions. The pressure to eliminate these restrictions, they claim, should be higher in those states with fewer small banks, so state bank deregulation should be observed earlier in those states.

Our theoretical model follows the line of reasoning found in the literature on credible spatial preemption. ${ }^{9}$ The general argument states that in a spatial competition model firms may find it profitable to concentrate their activities in a single location. Entry into another region leads to competition with other firms, which in turn, affects the demand for its product in the original geographical market and may, consequently, reduce the firm's aggregate profits. In fact, as we will show in the paper, the decision to expand geographically will depend on transportation costs or, in our case, the costs of performing long-distance transactions.

The organization of the paper is as follows. Section 2.2 provides a brief description of the changes implemented in the banking sector in terms of interstate branching restrictions. Section 2.3 presents the basic setup. Section 2.4 solves the spatial competition model, and section 2.5 extends the original framework to incorporate difference in operating costs across banks and setup costs. Finally, section 2.6 concludes.

\footnotetext{
${ }^{9}$ See, for example, Judd (1985).
} 


\subsection{Banking Deregulation: Brief Historical Review}

The discussion about bank branching restrictions in the U.S. can be traced back to 1864 , when the Congress passed the first major national banking legislation in the United States. ${ }^{10}$ The National Banking Act of 1864 provided banks (among other things) the alternative to choose between federal or state chartering legal scheme. In other words, they were able to choose the level of government that would regulate their operations. The McFadden Act of 1927 applied this principle to branch banking regulation. In general, the Act prevented national banks from branching. However, they were allowed to establish offices in other sates if and only if a state law permits a state chartered bank to take the same action.

The McFadden Act was passed by Congress after long debates between opponents and proponents of branching restrictions. ${ }^{11}$ Proponents argued that bank branches would not be able to serve the needs of their host communities. They believed that banking services must be provided at unit banks because they would be more familiar with the needs of a particular community. Opponents of branching restrictions stressed the necessity of risk diversification. Branching, they claimed, would allow the banking system to transfer loanable funds from areas of low demand to areas with a higher level of need. However, these transfers were characterized by those in favor of the branching restrictions as money draining away from rural communities to be used for speculative investments in far away home office cities. ${ }^{12}$

The most important argument in the bank branching debate was the efficiency problem. Those against branching restrictions considered that individual branches could participate in multiple markets and offer services to specific market needs in a manner that would be too risky and costly for local unit banks. The proponents of branch restriction believed that branches

\footnotetext{
${ }^{10}$ See Rollinger (1996) for a thorough description of the history of banking regulation.

11 See Senzel (1992) and Mulloy (1995).

${ }^{12}$ See Gilbert (2000).
} 
generated market concentration. They feared that concentration of resources would reduce competition and thereby reduce the quality and quantity of services provided to a community.

Several banks attempted in many different ways to avoid the bank branching restriction exploiting the fact that the law was not precise on some issues. ${ }^{13}$ Amendments were introduced later to solve a number of ambiguities present in the regulation. After some time, the branching restriction could no longer be sustained. Bank failures spread out around the country. Moreover, US banks were notably more inefficient relative to European banks. Foreign investment in the banking sector dramatically dropped because the restriction did not discriminate among domestic and international banks. ${ }^{14}$ In addition, technological progress in the banking industry made it clear that the geographical restrictions to open a branch or subsidiary in other states should be relaxed or eliminated. Senzel (1992) and Krozner and Strahan (1996), for instance, claim that technological progress was one of the major reasons that explain the change of the status quo in terms of bank regulation.

The deregulation process started in the early 1970s. The first step consisted on the elimination of intrastate branching restrictions. ${ }^{15}$ Then, the deregulation process extended to interstate branching restrictions. Cross-state ownership of banks was not permitted until the early 1980s. At that time, many states passed different laws allowing the entry of out-of state banks as long as other states reciprocate, i.e., if their banks were also given the opportunity to operate in those states. ${ }^{16}$ In 1994, the deregulatory process was completed with the Riegle-Neal Act that permitted nationwide branching as of June 1997.

\footnotetext{
${ }^{13}$ Tart (1995) describes several specific attempts put into practice by different banks to avoid the regulation. The most typical case involved the First National Bank. This bank was sued and the Supreme Court found illegal the attempt to collect cash and checks in a car service. The bank also attempted to establish "secured receptacles" where customers could leave deposits to be picked up by the armored car. Courts decided that an armored car service constitutes a branch whenever the bank or affiliate owns or operates the service.

${ }^{14}$ See Mulloy (1995).

${ }_{16}^{15}$ By 1994, most states permitted intrastate branching (Strahan (2003)).

${ }^{16}$ In fact, Maine was the first state to pass a law like this in 1978, but not state reciprocated, so the interstate deregulation process was delayed until 1982 when Alaska and New York passed similar laws. See Kane (1996), Kroszner and Strahan (1999), and Strahan (2003).
} 
Some restrictions are still imposed in the formation of branches or the conversion of a bank holding company into a branch in order to prevent bank concentration. For instance, a branch cannot have more than 30 percent of the deposits held by insured depository institutions in a particular state, unless the host state eliminates the limitations entirely or has a lower concentration restriction. In addition, the Federal Reserve is prohibited from approving an acquisition if, as a result, the bank holding company would control more than 10 percent of the total amount of deposits of insured depository institutions in the United States.

The organization of the paper is as follows. Section 2.2 provides a brief description of the changes implemented in the banking sector in terms of interstate branching restrictions. Section 2.3 presents the basic setup. Section 2.4 solves the spatial competition model, and sections 2.5 and 2.6 introduce different extensions to the original framework. Finally, section 2.7 concludes.

\subsection{The Model}

We assume an economy with two banks, 1 and 2, and two regions, A and B. Initially, bank 1 exclusively locates in region A and 2 in region B. Each region is populated by a mass of investors, which has been normalized to one. Investors in each region can borrow from either bank. Bank $j$ charges an interest rate $r_{j}^{i} \geq 0$ to investors in region $i$. The operating costs of bank $j$ are $c_{j} \geq 0$. If investors borrow from a bank that is located in the other region, they incur in a transportation cost $t>0$, which is charged to the loan interest rate. The parameter $t$ represents the cost of performing long-distance transactions. Investment projects in each region yield a gross return equal to $\beta>0 .{ }^{17}$ Investors borrow from the bank that offers the lowest interest rate. The net return to investors is $\beta$ minus the interest rate. Investors can always choose not to borrow, in which case they obtain zero profits.

\footnotetext{
${ }^{17}$ For simplicity, the return to investors is assumed to be the same across regions.
} 
We consider a spatial competition model between banks 1 and 2 in two different settings. First, we assume that banks cannot expand their activities to other regions, i.e., banks can only locate in one single region and cannot open a branch elsewhere. Even though banks are physically restricted from operating in other places, they can still target distant consumers from their own locations, as long as the cost of performing long-distance transactions is taken into account. Thus, bank 1 and 2 choose, respectively, $\mathrm{r}_{1}{ }^{\mathrm{A}}$ and $\mathrm{r}_{2}{ }^{\mathrm{B}}$. Investors observe the interest rates offered by the banks and choose the action that maximizes their payoffs, which, in this case, are given by

\section{Table 3.1 The Consumer Payoffs with branching restrictions}

$$
\mathrm{U}^{\mathrm{A}} \equiv\left\{\begin{array} { l l } 
{ \beta - \mathrm { r } _ { 1 } ^ { \mathrm { A } } } & { \text { if borrow from bank 1, } } \\
{ \beta - \mathrm { r } _ { 2 } ^ { \mathrm { B } } - \mathrm { t } } & { \text { if borrow from bank 2, } } \\
{ 0 } & { \text { otherwise, } }
\end{array} \quad \mathrm { U } ^ { \mathrm { B } } \equiv \left\{\begin{array}{ll}
\beta-\mathrm{r}_{1}^{\mathrm{A}}-\mathrm{t} & \text { if borrow from bank 1, } \\
\beta-\mathrm{r}_{2}^{\mathrm{B}} & \text { if borrow from bank 2, } \\
0 & \text { otherwise }
\end{array}\right.\right.
$$

Given the investors' behavior, banks compete in interest rates (Bertrand competition).

Alternatively, we consider an environment where bank branching restrictions are no longer present. Specifically, suppose that bank 1 has the alternative of opening a branch in region $\mathrm{B}$. We assume in this section that, for exogenously given reasons, bank 2 still only operates in $\mathrm{B} .^{18}$ Therefore, without branching constraints, bank 1 will choose the best alternative among the following options: (i) continue operating exclusively in region A, or (ii) operate in both regions at the same time. If bank 1 chooses not to enter region B (i.e., case (i)), then the previous game is played where banks determine the level of $r_{1}{ }^{\mathrm{A}}$ and $\mathrm{r}_{2}{ }^{\mathrm{B}}$ and investors decide the best action according to (1). If, on the other hand, bank 1 enters region $\mathrm{B}$, then bank 1 chooses $\mathrm{r}_{1}{ }^{\mathrm{A}}$ and $\mathrm{r}_{1}{ }^{\mathrm{B}}$ and bank 2 chooses $r_{2}{ }^{B}$. In this situation, investors' utilities are given by

\footnotetext{
${ }^{18}$ Bank 2 is considered a local bank. In the next section, we allow operation costs to differ across banks and bank 2 is assumed to be "less efficient" than bank 1.
} 


\section{Table 3.2 Consumer Payoff in Scenario II without branching restrictions}

$U^{A} \equiv\left\{\begin{array}{ll}\beta-r_{1}^{A} & \text { if borrow from bank 1 in A, } \\ \beta-r_{1}^{B}-t & \text { if borrow from bank 1 in B, } \\ \beta-r_{2}^{B}-t & \text { if borrow from bank 2 in } B, \\ 0 & \text { otherwise, }\end{array} \quad U^{B}= \begin{cases}\beta-r_{1}^{A}-t & \text { if borrow from bank 1 in A, } \\ \beta-r_{1}^{B} & \text { if borrow from bank 1 in B, } \\ \beta-r_{2}^{B} & \text { if borrow from bank 2 in B, } \\ 0 & \text { otherwise. }\end{cases}\right.$

As before, they decide the best action after observing the interest rates offered by the banks.

The figure below outlines the extensive-form representation of the previously defined games.

\section{Figure 3.1 Extensive form representation of the game.}

\begin{tabular}{|c|}
\hline Initial Situation: \\
Bank 1 in A \\
Bank 2 in B
\end{tabular}

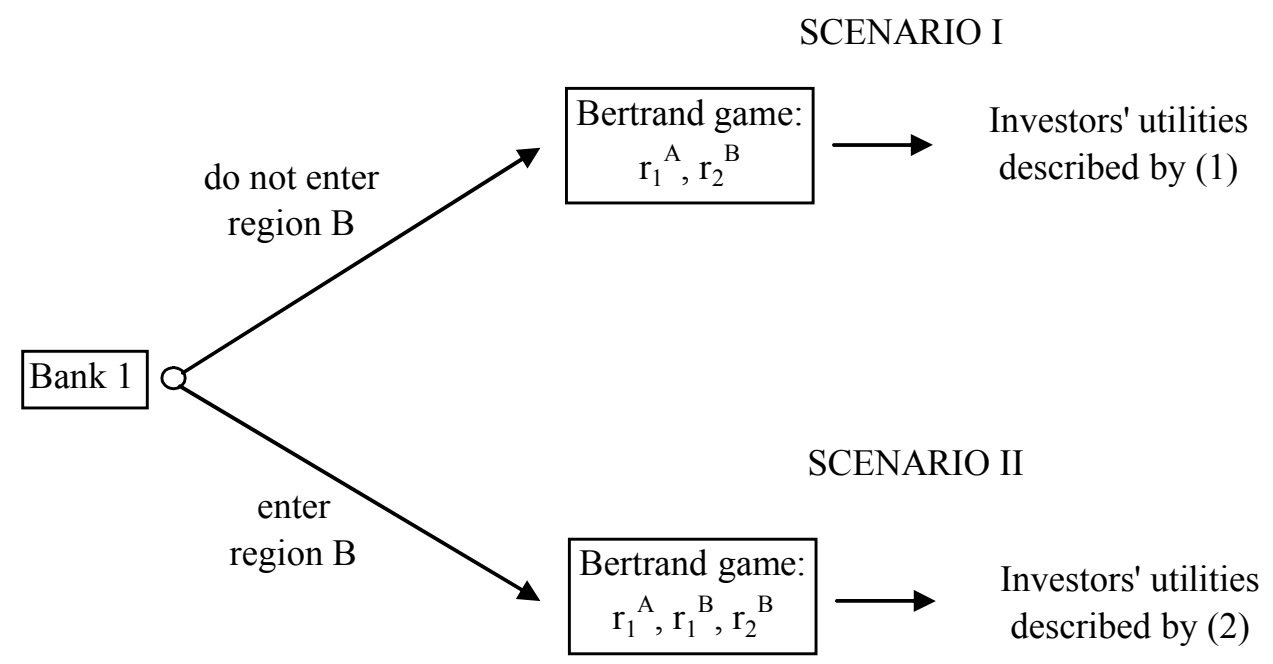

Scenario I takes place if bank 1 does not enter region B. In this case, banks 1 and 2 play a Bertrand game anticipating investors' actions. In other words, they choose $\mathrm{r}_{1}{ }^{\mathrm{A}}$ and $\mathrm{r}_{2}{ }^{\mathrm{B}}$ considering that investors select the action that maximizes their utilities according to (1). In the presence of branching restrictions, this is the only alternative for bank 1. But without these constraints, bank 1 will also evaluate the possibility of entering region $\mathrm{B}$, in which case the game represented by Scenario II is played. In this case, a different Bertrand game takes place where banks simultaneously choose $\mathrm{r}_{1}{ }^{\mathrm{A}}, \mathrm{r}_{1}{ }^{\mathrm{B}}$, and $\mathrm{r}_{2}{ }^{\mathrm{B}}$ given that investors select the best alternative as indicated by (2). Anticipating these outcomes, bank 1 determines at the beginning of the game whether it is profitable or not to open another office in region B. 
In all cases, we derive the sub-game perfect Nash Equilibria for different relationships between the exogenous variables $\beta$ and t and calculate investors' welfare and banks' profits in the two environments described above: with and without branching restrictions. Our objective is to evaluate how the results change when the cost of performing long-distance transactions, $t$, declines (relative to $\beta$ ). ${ }^{19}$ Next, we compare the results, determine the conditions that would drive bank 1 to open a branch in region B, and establish who would benefit and lose if bank 1 decided to take this action. In light of these results, we will evaluate the effectiveness of the regulation that prohibits banks to open branches in other places. In other words, if bank 1 obtains higher profits in Scenario I than in Scenario II, then the constraint would not be binding.

The next section considers a simplified version of the model in which banks' operating costs are equal and equal to zero. This model captures the essential arguments of the discussion on branching restrictions. The following section extends the basic framework by assuming that operating costs differ across banks and by assuming that bank 1 must pay a fixed cost when it decides to open a branch in region $\mathrm{B}$.

\subsection{The Model with Identical Costs}

In this section, we assume that banks' operation costs (and fixed costs) are zero, i.e., $c_{j}=0$, for $j$ $=1,2$. As explained before, we obtain the sub-game perfect Nash Equilibria, which implies solving the game using backward induction. At the end of the game, investors choose the action that maximizes their utilities according to (1) or (2). In deciding the interest rates, banks anticipate the investors' behavior. The competition between banks critically depends on whether bank 1 enters or not region B. Scenario I represents the sub-game in which bank 1 locates in A and bank 2 in B. Scenario II, on the other hand, represents a situation where bank1 decides to

\footnotetext{
${ }^{19}$ For banking transactions, this cost has significantly decreased in the last 50 years, which may have affected banks' incentives to open branches elsewhere. We assume that bank location is exogenously determined in our model. A Nash Equilibrium may not exist if banks also select their location. Some papers show the existence of a Nash Equilibrium under certain specific assumptions. See, for example, Prescott (1979).
} 
open an office in region B. The following two subsections derive the Bertrand Nash Equilibrium and compare the solutions obtained in the two scenarios. We will later compare the solutions and examine the conditions under which banks 1 would find it profitable to open a branch.

\subsubsection{Scenario I: bank 1 operates in A and bank 2 operates in B}

In this case, the payoffs for different actions available to investors in A and B are described by (1). Investors choose the action that maximizes their utilities. Recall that they do not borrow from a bank if the net return is negative. ${ }^{20}$

Suppose that (i) $\mathrm{t}<\beta$; (ii) $\mathrm{t}=\beta$; and (iii) $\beta<\mathrm{t}$ represents three different cases that correspond, respectively, to low, medium, and high transaction or transportation costs. In addition, we assume that $\beta<2$ t. The following proposition describes the Bertrand equilibrium $\left(\mathrm{r}_{1}{ }^{\mathrm{A}}, \mathrm{r}_{2}{ }^{\mathrm{B}}\right)$ and the resulting equilibrium payoffs for consumers and banks.

Proposition 1. Consider the duopoly sub-game in which bank 1 locates in region A and bank 2 in B. For all cases (i) $t<\beta<2 t$, (ii) $t=\beta<2 t$; and (iii) $\beta<t<2 t$, the equilibrium interest rates are $r_{1}^{A}=r_{2}^{B}=\beta$, investors in $A$ borrow from bank 1, investors in B borrow from bank 2, investors' welfare in both regions is 0 , and banks' profits are $\beta$.

Proof: Case (i): $t<\beta<2$ t. We need to show that no bank can increase its profit by undercutting the price of the other bank. Suppose that bank 2 chooses $r_{2}{ }^{B}=\beta$. If bank 1 would like to attract investors located in region $\mathrm{B}$, the interest rate has to be at most the interest rate that they can get in region $B\left(r_{2}{ }^{B}\right)$ minus t, i.e., $r_{1}{ }^{A}=r_{2}{ }^{B}-t=\beta-t$. In this case, profits for bank $A$ would be given by $\pi_{1}{ }^{\mathrm{A}}=2(\beta-\mathrm{t})$. However, when it does not undercut and charges $\mathrm{r}_{1}{ }^{\mathrm{A}}=\beta$, profits become $\pi_{1}{ }^{\mathrm{A}}=$ $\beta$, which are higher than $2(\beta-\mathrm{t})$ because $\beta<2 \mathrm{t}$. A similar argument applies to bank 2 . Hence, $\left(r_{1}{ }^{A}, r_{2}{ }^{B}\right)$ are the equilibrium tax rates, $U^{A}=U^{B}=0$, and $\pi_{1}{ }^{A}=\pi_{2}{ }^{B}=\beta$. Case (ii): $t=\beta<2$ t. If

\footnotetext{
${ }^{20} \mathrm{We}$ assume that if investors are indifferent between borrowing from any bank, they will actually borrow from the local one.
} 
bank 1 undercuts, then it would set again $r_{1}{ }^{A}=\beta-t=0$, so that $\pi_{1}{ }^{A}=0$. If, on the other hand, it does not undercut, then $r_{1}{ }^{\mathrm{A}}=\beta>0$, and $\pi_{1}{ }^{\mathrm{A}}=\beta>0$. Hence, we obtain the same results as in (i). Case (iii): $\beta<\mathrm{t}<2 \mathrm{t}$. If bank 1 undercuts, then it would set $\mathrm{r}_{1}{ }^{\mathrm{A}}=\beta-\mathrm{t}<0$, and obtain $\pi_{1}{ }^{\mathrm{A}}<0$; if it does not undercut, $\mathrm{r}_{1}{ }^{\mathrm{A}}=\beta>0$, and obtain $\pi_{1}{ }^{\mathrm{A}}=\beta>0$. Thus, the previous results still hold.

\subsubsection{Scenario II: bank 1 opens a branch in region $B$}

Now, we examine a situation where bank 1 opens a branch in region B. The utility of investors located in A and B are given by (2). Suppose that $t<\beta<2 t$. Since two banks operate in B, price competition drives interest rates to zero in that region, i.e., $r_{1}{ }^{B}=r_{2}{ }^{B}=0$. Thus, bank 1 will never be able to attract all investors in B. Given that investors in A have the possibility of borrowing at 0 interest rates from any bank in $\mathrm{B}$, the highest interest rate bank 1 can charge in region $\mathrm{A}$ is $\mathrm{r}_{1}{ }^{\mathrm{A}}$ $=\mathrm{t}$. For this interest rate, the utility of investors in $\mathrm{A}$ is $\mathrm{U}^{\mathrm{A}}=\beta-\mathrm{t}$ when they borrow from bank 1 , and $U^{A}=\beta-t-r_{j}^{B}=\beta-t$ when they borrow from bank $j$ in $B$, so they are indifferent between the two alternatives. The same reasoning applies when $\mathrm{t}=\beta<2 \mathrm{t}$. If $\beta<\mathrm{t}<2 \mathrm{t}$, the highest interest rate that bank 1 can charge is $\beta$ since investors have a zero reservation utility. In these last two cases, the utility of those residing in A is zero. The following proposition summarizes the results.

Proposition 2. Consider the duopoly sub-game in which bank 1 locates in regions $A$ and $B$ and bank 2 locates in region $B$. Then,

(i) if $t<\beta<2 t$, the equilibrium interest rates are $r_{1}{ }^{A}=t, r_{1}{ }^{B}=r_{2}{ }^{B}=0$, investors in $A$ borrow from bank 1, investors in B borrow either from bank 1 or bank 2 in B, investors' utility in region $A$ is $(\beta-t)>0$, investors' utility in region $B$ is 0 , bank 1 's profits are $t$, and bank 2 's profits are 0 ;

(ii) if $t=\beta<2 t$, equilibrium interest rates are $r_{1}^{A}=t, r_{1}{ }^{B}=r_{2}{ }^{B}=0$, investors in $A$ borrow from bank 1, investors in B borrow either from bank 1 or bank 2 in B, investors' utility in both regions is 0 , bank 1 's profits are $t=\beta$, and bank 2 's profits are 0 ; 
(iii) if $\beta<t<2 t$, the equilibrium interest rates are $r_{1}^{A}=t, r_{1}^{B}=r_{2}^{B}=0$, investors in $A$ borrow from bank 1, investors in B borrow either from bank 1 or bank 2 in B, investors' utility in both regions is 0 , bank 1 's profits are $t$, and bank 2 's profits are 0.

\subsubsection{Comparing the results}

In this section, we compare the results obtained in Scenarios I and II, which will allow us not only to determine who benefits and who loses in both situations, but also examine whether it would be profitable for bank 1 to open a branch in region B or not. The outcomes of the last two models are summarized in Table 2.3 below.

Table 3.3 Summary of Results: $\mathrm{c} 1=\mathrm{c} 2=0$

\begin{tabular}{|c|c|c|c|c|c|c|}
\hline \multirow{2}{*}{ Bank Location } & \multirow{2}{*}{ Condition } & \multirow{2}{*}{$\mathrm{NE}$} & \multicolumn{2}{|c|}{ Investor Welfare } & \multicolumn{2}{|c|}{ Bank Profits } \\
\hline & & & Region A & Region B & Bank 1 & Bank 2 \\
\hline $\begin{array}{l}\text { Scenario } \\
\text { Bank } 1 \text { in A - } \\
\text { Bank } 2 \text { in B }\end{array}$ & $\begin{array}{l}\mathrm{t}<\beta<2 \mathrm{t} \\
\mathrm{t}=\beta<2 \mathrm{t} \\
\beta<\mathrm{t}<2 \mathrm{t}\end{array}$ & $\begin{array}{l}\mathrm{r}_{1}^{\mathrm{A}}=\mathrm{r}_{2}^{\mathrm{B}}=\beta \\
\mathrm{r}_{1}^{\mathrm{A}}=\mathrm{r}_{2}^{\mathrm{B}}=\beta \\
\mathrm{r}_{1}^{\mathrm{A}}=\mathrm{r}_{2}{ }^{\mathrm{B}}=\beta\end{array}$ & $\begin{array}{l}0 \\
0 \\
0\end{array}$ & $\begin{array}{l}0 \\
0 \\
0\end{array}$ & $\begin{array}{l}\beta \\
\beta=\mathrm{t} \\
\beta\end{array}$ & $\begin{array}{l}\beta \\
\beta=t \\
\beta\end{array}$ \\
\hline $\begin{array}{l}\text { Scenario II: } \\
\text { Bank } 1 \text { in A and B - } \\
\text { Bank } 2 \text { in B }\end{array}$ & $\begin{array}{l}\mathrm{t}<\beta<2 \mathrm{t} \\
\mathrm{t}=\beta<2 \mathrm{t} \\
\beta<\mathrm{t}<2 \mathrm{t}\end{array}$ & $\begin{array}{l}\mathrm{r}_{1}^{\mathrm{A}}=\mathrm{t} \\
\mathrm{r}_{1}^{\mathrm{B}}=\mathrm{r}_{2}^{\mathrm{B}}=0 \\
\mathrm{r}_{1}^{\mathrm{A}}=\mathrm{t} \\
\mathrm{r}_{1}{ }^{\mathrm{B}}=\mathrm{r}_{2}^{\mathrm{B}}=0 \\
\mathrm{r}_{1}^{\mathrm{A}}=\beta \\
\mathrm{r}_{1}^{\mathrm{B}}=\mathrm{r}_{2}^{\mathrm{B}}=0\end{array}$ & $\begin{array}{l}\beta-\mathrm{t} \\
0 \\
0\end{array}$ & $\begin{array}{l}\beta \\
\beta \\
\beta\end{array}$ & $\begin{array}{l}\mathrm{t} \\
\beta=\mathrm{t} \\
\beta\end{array}$ & $\begin{array}{l}0 \\
0 \\
0\end{array}$ \\
\hline
\end{tabular}

The first column of the table indicates the two different scenarios. The second column considers different relationships between $\beta$ and t. The last five columns present the Nash Equilibrium and the payoffs for each one of the cases. Four interesting observations are worth emphasizing.

First, investors in region B are always strictly better-off in Scenario II, while investors in region $A$ are never worse-off. In fact, if $t<\beta<2 t$, their welfare increases to $(\beta-t)>0$ when bank 1 opens a branch in $\mathrm{B}$. This result is explained by the fact that Bertrand competition in region $\mathrm{B}$ drives interest rates down, benefiting residents of that region. Aggregate investor welfare is unambiguously higher in Scenario II. Second, profits of the immobile bank located in 
region B are lower for every case in Scenario II. Finally, total welfare, as measured by the simple sum of investors' utilities and banks' profits is equal to $2 \beta$ in all cases.

Bank 1, at the beginning of the game, decides whether to operate in region B or not by comparing profits obtained in Scenario I and II. It is not profitable for bank 1 to open a branch when $\mathrm{t}<\beta<2 \mathrm{t}$. However, it is indifferent between Scenarios I and II when $\beta \leq \mathrm{t}<2 \mathrm{t}$. The intuition behind this last result is clear. When bank 1 enters the market in region $\mathrm{B}$, the interest rate falls to zero in that region. Given this reduction in the interest rate, investors in A would be tempted to borrow from B. Hence, bank 1 in A would need to reduce the interest rate in A to prevent this kind of behavior. If $\mathrm{t}<\beta<2 \mathrm{t}$, bank 1 would suffer a profit reduction as a result of this action. Only when transactions costs are high, i.e., $\beta \leq \mathrm{t}<2 \mathrm{t}$, bank 1 will open a branch in another region since profits are the same in the two scenarios. The last result is restated as a proposition below.

Proposition 3. It is not profitable for bank 1 to open a branch in region $B$ when $t$ is low, in particular, if $t<\beta<2 t$. If $\beta \leq t<2 t$, bank 1 is indifferent between Scenarios I and II.

Thus, any regulation that prevents banks from opening branches or subsidiaries in other regions would only make sense if transportation costs or the cost of performing long-distance transactions is large.

The model is able to identify those individuals that benefited from the McFadden Act of 1929 that regulated bank branching. According to our results, branching restrictions would only benefit banks in region $\mathrm{B}$. Therefore, bank owners in regions that could be threatened by the entry of big banks would presumably promote branching restrictions. Carrow (1998) in an empirical work showed that returns to some big institutions (like in our model bank 1) were obtained as a consequence of relaxing the interstate branching restrictions. 
However, in our model, these restrictions are relevant only when transaction costs are high. Only in this case will banks find it profitable to open branches. Transactions costs were relatively high at the beginning of the 1900s. The implementation of branching restrictions at that time would be largely supported by "local banks" because banks from other regions would otherwise open branches driving the profits of local banks to zero. The decline in these costs due to technological improvements observed in the banking industry made the branching restrictions irrelevant and obsolete as banks will prefer to operate from a single location.

A few papers have used similar explanations to justify the enforcement of different regulations in the banking sector. Kane (1996), for instance, uses a special interest group theory to explain why regulatory measures were implemented and why it took so long to get rid of these restrictions. Kane also believes that there was no reason to maintain the branching restrictions due to the technological advances in the banking sector. Krozner and Strahan (1998) find that interest group factors related to the relative strength of potential winners (which are basically large banks) and losers (small banks) can explain the timing of branching deregulation across states during the last four decades.

\subsection{The Model with Heterogeneous Operating Costs and Positive Set-up Costs}

In this section, we extend the previous model by assuming that banks 1 and 2 have different operating or variable costs. Specifically, $c_{2}>c_{1}=0 .{ }^{21}$ We also consider values of the parameters such that $c_{2}<\beta<2$ t. $^{22}$ Table 2.4 shows the equilibrium interest rates, investors' welfare and profits in the two scenarios described previously. ${ }^{23}$ In solving the game, we use the following rule for splitting up consumers between banks when interest rates are equal: if residents of A and $\mathrm{B}$ are indifferent between banks located in different regions, then they will borrow from the bank

\footnotetext{
${ }^{21}$ This assumption attempts to capture the idea that the bank that actually has the alternative to open a branch in another region, in this case bank 1 , is effectively the bank with lower operating costs or more efficient.

${ }^{22}$ If $\beta<c_{2}$, then bank 2 will decide not to operate at all.

${ }^{23}$ The equilibria are obtained in a similar way as in Section III. We do not include the derivations here, but, of course, are available upon request.
} 
located in their respective region; in Scenario II, if residents in B are indifferent between borrowing from bank 1 or 2 , then the rule assigns all consumers to bank 1 in that region. ${ }^{24}$

Table 3.4 Heterogeneous Variable Costs: $\mathrm{c} 2>\mathrm{c1}=\mathbf{0}, \beta>\mathrm{c} 2$

\begin{tabular}{|c|c|c|c|c|c|c|}
\hline \multirow{2}{*}{ Bank Location } & \multirow{2}{*}{ Condition } & \multirow{2}{*}{$\mathrm{NE}$} & \multicolumn{2}{|c|}{ Investor Welfare } & \multicolumn{2}{|c|}{ Bank Profits } \\
\hline & & & Region A & Region B & Bank 1 & Bank 2 \\
\hline \multirow{3}{*}{$\begin{array}{l}\text { Scenario } \\
\text { Bank } 1 \text { in A - } \\
\text { Bank } 2 \text { in B }\end{array}$} & $\mathrm{c}_{2}+\mathrm{t}<\beta<2 \mathrm{t}$ & $\mathrm{r}_{1}^{\mathrm{A}}=\mathrm{r}_{2}^{\mathrm{B}}=\beta$ & 0 & 0 & $\beta$ & $\beta-c_{2}$ \\
\hline & $c_{2}+t=\beta<2 t$ & $\mathrm{r}_{1}^{\mathrm{A}}=\mathrm{r}_{2}^{\mathrm{B}}=\beta$ & 0 & 0 & $\beta$ & $\beta-c_{2}$ \\
\hline & $\beta<\mathrm{c}_{2}+\mathrm{t}<2 \mathrm{t}$ & $\mathrm{r}_{1}^{\mathrm{A}}=\mathrm{r}_{2}^{\mathrm{B}}=\beta$ & 0 & 0 & $\beta$ & $\beta-c_{2}$ \\
\hline \multirow{3}{*}{$\begin{array}{l}\text { Scenario II: } \\
\text { Bank } 1 \text { in A and B - } \\
\text { Bank } 2 \text { in B }\end{array}$} & $\mathrm{c}_{2}+\mathrm{t}<\beta<2 \mathrm{t}$ & $\begin{array}{l}\mathrm{r}_{1}{ }^{\mathrm{A}}=\mathrm{c}_{2}+\mathrm{t} \\
\mathrm{r}_{1}{ }^{\mathrm{B}}=\mathrm{c}_{2}, \mathrm{r}_{2}{ }^{\mathrm{B}} \geq \mathrm{c}_{2}\end{array}$ & & & & 0 \\
\hline & $\mathrm{c}_{2}+\mathrm{t}=\beta<2 \mathrm{t}$ & $\begin{array}{l}\mathrm{r}_{1}=\beta \\
\mathrm{r}_{1}{ }^{\mathrm{B}}=\mathrm{c}_{2}, \mathrm{r}_{2}{ }^{\mathrm{B}} \geq \mathrm{c}_{2}\end{array}$ & 0 & $\beta-c_{2}$ & $\beta+c_{2}$ & 0 \\
\hline & $\beta<c_{2}+t<2 t$ & $\begin{array}{l}\mathrm{r}_{1}=\beta \\
\mathrm{r}_{1}^{\mathrm{B}}=\mathrm{c}_{2}, \mathrm{r}_{2}^{\mathrm{B}} \geq \mathrm{c}_{2}\end{array}$ & 0 & $\beta-c_{2}$ & $\beta+c_{2}$ & 0 \\
\hline
\end{tabular}

Most of the results are similar to the previous ones. For instance, investors in B become betteroff, investors in region A are never worse-off ${ }^{25}$, and bank 2 in B has lower profits in Scenario II. However, there are a few exceptions. First of all, bank 2 is now forced to leave the market when bank 1 opens a branch in region B. In Scenario II, the best response by bank 2 consists on setting any interest rate greater than or equal to $c_{2}$. Consequently, nobody borrows from bank 2 and its profits are zero. Second, total welfare, calculated as the sum of investors' utility and banks' profits are higher in Scenario II. In Scenario I, total welfare is $2 \beta-\mathrm{c}_{2}$, while in Scenario II, it becomes $2 \beta$. Third, bank 1's profits are higher in Scenario II when $\beta \leq \mathrm{c}_{2}+\mathrm{t}<2 \mathrm{t}$, while profits are higher in Scenario I if and only if $\mathrm{t}$ is sufficiently small, i.e., $\mathrm{t}<\beta-2 \mathrm{c}_{2}$ (or $\mathrm{t}$ is such that $2 \mathrm{c}_{2}+$ $\mathrm{t}<\beta$ ). For this last condition to be relevant, we also require $\beta>2 \mathrm{c}_{2}$. Note that if the latter

\footnotetext{
${ }^{24}$ To simplify the derivations, we assume a specific division of consumers between banks when they charge the same interest rates. The idea of splitting up consumers in the way specified in the text is justified on the grounds that, if $r_{i}^{j}$ is a continuous variable, then an equilibrium does not exist. Bank 1 would want to choose an interest rate very close to $c_{2}$, but not equal to $c_{2}$. For instance, bank 1 would pick $r_{1}{ }^{B}=c_{2}-\varepsilon$, where $\varepsilon$ is positive and very close to zero. However, such $\varepsilon$ does not exist. If, on the other hand, we assume that bank 1 gets all the consumers when $\mathrm{r}_{1}{ }^{\mathrm{B}}=$ $\mathrm{r}_{1}^{\mathrm{A}}=\mathrm{c}_{2}$, then there is no discontinuity at $\mathrm{c}_{2}$ and an equilibrium exist. Alternatively, we could have worked with a grid of discrete interest rates (instead of a continuum of interest rates). It is easy to show that, in this case, the equilibria in pure strategies will converge to the proposed solutions when the grid becomes finer.

${ }^{25}$ The results goes along the line of Dick (2003) who points out the positive effect of deregulation on banks' quality services.
} 
inequality does not hold, it will always be profitable for bank 1 to open a branch in region B. Thus, in order for Scenario I to be preferred to Scenario II for bank 1 when $\mathrm{c}_{2}+\mathrm{t}<\beta$, $\mathrm{t}$ and $\mathrm{c}_{2}$ both have to be sufficiently low. Hence, the more efficient bank would only open a branch when $\mathrm{t}$ or $\mathrm{c}_{2}$ are sufficiently large. The following proposition summarizes this last result.

Proposition 4. Bank 1 maximizes its profit by opening a branch in region $B$ when $c_{2}$ and $t$ are such that $\beta \leq 2 c_{2}+t$. It maximizes profits by completely withdrawing from region $B$ if $2 c_{2}+t<$ $\beta$.

The outcome of this model also reveals that bank branching would lead to bank concentration if transaction costs are relatively high and/or local banks are very "inefficient" in the sense that their operating costs $c_{2}$ are large. In this case, banks from other locations would have an incentive to open branches and inefficient local will be forced out of the market. On the other hand, the elimination of the branching restrictions do not have any effect if transactions costs are sufficiently low given that big or efficient banks no longer have an incentive to open branches elsewhere.

Therefore, technological changes in the banking made, in some way, the MacFadden Act (1927) obsolete as branching restrictions are no longer binding when the cost of performing long-distance transactions is low enough. The necessity to update banking regulation in terms of the advances verified in the sector resulted in the Riegle Neal Act of 1994. Our model predicts that this law should not have had any significant effect given that it just eliminated a restriction that was no longer binding.

Now suppose that if bank 1 opens a branch in $B$, it faces a setup cost equal to $\theta$. Then, at the beginning of the game, bank 1 will decide to open an office in B if profits in Scenario II minus $\theta$ 
are at least as big as those obtain Scenario II. In this way, Proposition 4 should be restated as follows:

Proposition 4'. Bank 1 maximizes its profit by opening a branch in region $B$ when $c_{2}$ and $t$ are such that $\beta \leq 2 c_{2}+t-\theta$. It maximizes profits by completely withdrawing from region $B$ if $2 c_{2}+t$ $-\theta<\beta$.

The consideration of setup costs decreases the likelihood of bank 1 entering into region B when no branching restrictions are present.

\subsection{Conclusions}

The paper develops a spatial competition model in which banks compete in prices. Two different scenarios are considered. The first one assumes that banks cannot open a branch or a subsidiary in another region. The second scenario assumes that there are no branching restrictions. We derive the Nash Equilibria and determine winners and losers in each case. Additionally, we examine whether the incentives to open a branch are affected when the cost of performing longdistance transactions decreases, as evidenced in the banking sector.

The model concludes that branching restrictions are not binding when technological advances reduced the cost of performing long-distance transactions. This means that the MacFadden Act of 1927, which prevented banks from opening branches in other states, becomes completely obsolete under these conditions. The necessity to update banking regulation in terms of the advances verified in the sector resulted in the Riegle Neal Act of 1994. Our model predicts that this law only updated the legislation and made it consistent with the economic reality in the banking sector. In other words, it just eliminates a restriction that was no longer binding. 
Chapter 4

Branch Deregulation in the US Banking System 


\subsection{Introduction}

The McFadden Act (1927) established a restriction that prevented banks from opening a branch or subsidiary in another state. This law was in effect from 1927 to 1994, when a Federal Law called "Riegle-Neal Interstate Banking and Branching Efficiency Act of 1994" (Act of 1994) was released. ${ }^{26}$ One of the objectives of the Act of 1994 was to enhance efficiency in the banking sector. A 1981 report from the Carter Administration claimed that restrictions on interstate banking caused "inequities and inefficiencies", and removing such restrictions would, in their view, serve "the public interest". During the 1980's, more than 80 percent of failed-bank assets were in just four states: Texas, Illinois, New York and Oklahoma. The Report claims that “this failure problem could have been prevented by allowing more geographic diversification among banks".

The main objective of this paper is to evaluate changes in efficiency in the banking sector linked to banking deregulation. In addition, we evaluate whether bank deregulation affected the probability of bank failure.

Robert DeYoung (1998) and Carrow and Heron (1998) asserted that deregulation might enhance industry productivity in general. However for DeYoung (1998) there is a possibility that the change in efficiency may not be significant. The possibility of a change in the efficiency will depend on how a state considers their restriction. For instance, the states can take the restricted regulation as a previous stage to improve their competitiveness by making competitive entry barriers for their local banks.

The most contested argument in the branch banking debate was whether it would increase efficiency. The branch proponents believe that increasing the number of firms would allow

\footnotetext{
${ }^{26}$ In principle some states removed the branching restriction before, but the Act of 1994 extended the deregulation to all states.
} 
individual branches to participate in multiple markets and offer services to specific market needs that small local banks could not offer due to risk.

On the other hand, Kroszner and Strahan (1999) present a different explanation of branching restriction. They cite the relative political power of different interest groups that would benefit from the status quo of restricted diversification versus those that would benefit from expanding geographic areas. The authors also claim the importance of communications and technology as factors that permitted deregulation.

Garret, Wagner and Wheelock (2003) found that the decision of a state to adopt a specific bank regime depends on the regime adopted by other states. They point out that banks located in the Midwest and the South were the last to deregulate because those particular banks were in favor of restricting the entrance to larger banks. The smaller banks in the US are located in the Midwest and South.

In contrast, Avery and Samolyk (2004) accented the role of small banks in the consolidation of the financial system besides the high information cost that these types of banks have to overcome.

Jayaratne and Strahan (1996) found that branching deregulation encouraged efficient allocation of capital and, hence, induced higher growth rates. However, Freeman (2002) thinks that Jayaratne and Strahan's results are overestimated because the branching deregulation did not produce large effects.

Many papers analyze the determinants of efficiency, for instance, Berger and DeYoung (1997), Chen, Mason and Higgins (2001) and Guillen (2003) do some analysis of bank's efficiency. However, these papers do not study the influence of the regulation on efficiency by size and region.

Efficiency has been calculated using the Data Envelopment Analysis technique (DEA). DEA is a particular frontier analysis technique which measures the efficiency of a decision 
making unit (DMU). The DMU, in this case, are U.S banks, which will be analyzed across regions and different bank sizes. ${ }^{27}$

Efficiency varies across regions during 1984. Most of the efficient banks are located in the North while the least efficient are in the South. Some banks overcame this situation when they started to remove the branching restriction. We will verify if this change in efficiency over time and across regions has a positive effect for the banks regarding location and size.

In addition, we examine the effects that bank deregulation had on bank failure. We are interested to see if location and size can explain the failure of the bank.

The hypothesis within this paper is that the "State Branch Deregulation" increased efficiency and reduced failure. Riegle Neal Act of 1994 was enacted as a Federal Law to homogenize banking rules across states. Bank location and size effect are considered in this paper.

The rest of the paper is organized as follows: Section 3.1 describes the situation before and after the 1994 Act. Section 3.2 describes the Data Envelopment Analysis methodology. Section 3.3 presents the econometric models and the last section concludes.

\subsection{Situation Before and after 1994 Act}

The discussion on bank branching can be traced back to 1864 , when Congress passed the first major national banking legislation in the United States. The National Banking Act of 1864 (the "1864 Act" hence forth) established a uniform currency system for the U.S and created a market for government bonds to finance the Civil War. The passage of the 1864 Act provided banks the alternative to choose between a federal or state chartering legal scheme. In this way, banks were given the possibility to choose the laws and regulation under which they would be able to operate: federal or state. As a result, many national banks converted their federal charters

\footnotetext{
${ }^{27}$ The DEA methodology was formally introduced in a seminal paper by Farrel (1957) and later estimated by Charnes, Cooper and Rhode (1978).
} 
into state charters to take advantage of the favorable state branching laws. This imbalance endangered the existence of the entire national banking system.

The McFadden Act was passed by Congress in 1927. The act was originally intended to authorize national banks to establish branch offices within the limits of the banks' home city only when state law explicitly permitted state banks to branch in this way. In 1933, Congress amended the act by removing the home city restriction. Then national banks were given the authority to branch up to the border limits of the state, where state banks were permitted to take this action.

Congress passed the branch restriction act of 1927 after long debate. ${ }^{28}$ Opponents of branch banking argued that branches from large banks would not be able to serve the needs of their host communities. They also believed that banking services must be provided at unit banks because branch banks would be run by people that are not familiar with the needs of a particular community. Branching opponents also argued that local communities could grow because the local bank reinvests the loanable fund in the surrounding area.

The opponents of branching believed that branch banking was based on the theory of market concentration. These people feared that concentration of resources would reduce competition and thereby reduce the services provided to a community.

The proponents of branching, however, stressed the necessity of risk diversification in bank portfolio. They claimed that efficient redistribution of resources was possible by transferring loanable funds from areas of low demand to areas with a higher level of need. These transfers were characterized by opponents as draining money away from rural communities to be used for speculative investments in home office cities far from the local community.

\footnotetext{
${ }^{28}$ See Carrow and Larsen(1998) and Tart (1995) for a careful historic review
} 
There was a "special interest group" which was a proponent of the branching restrictions and obtained the enactment of the MacFadden act of 1927.

Therefore, there were many attempts to avoid bank branching restriction. ${ }^{29}$ The most typical case involved the First National Bank. This bank was sued and the Supreme Court found illegal the attempt to collect cash and checks in a car service. The bank also attempted to establish "secured receptacles" where customers could leave deposits to be picked up by an armored car. Courts decided that an armored car service constitutes a branch whenever the bank or affiliate owns or operates the service. In contrast, Bay National Bank and Trust Co. was allowed to uphold the operation of an armored car service owned by a third party. The ambiguity of verdicts was the consequence of the vagueness of the law's definition of "branch" in the McFadden Act (1927) and its amendments.

Another early attempt for banks to expand their frontiers of business geographically while avoiding "branching" was the establishment of loan production offices (LPOs), Automatic Teller Machines (ATM) and Bank Holding Companies (BHC). ${ }^{30}$ Courts found that each one of these alternatives was equivalent to bank branching. ${ }^{31}$

Given the necessity to expand geographically, regional agreements among banks emerged. The first reciprocal regional arrangement involved the New England states: Massachusetts, Connecticut, Vermont, New Hampshire, Maine, and Rhode Island.

During the 80 's, many banks failed which lead to the US financial banking crisis. In response to the savings and loan crisis of the 1980s, Congress enacted the St. Germain Act

\footnotetext{
${ }^{29}$ See a detailed explanation of the attempts in Tart (1995)

${ }^{30}$ The government enacted the Douglas Amendment (1956) that avoided the creation of BHCs. The BHCs were branching across the nation and this situation was not clearly defined as bank branching in the McFadden Act (1927).

${ }^{31}$ Section 36(f) of the McFadden Act consider an entity as a branch if it receives deposits, pays checks, or lends money.
} 
(1982) and the Federal Institutions Reform, Recovery and Enforcement Act of 1989 (FIRREA) ${ }^{32}$ to relief the crisis. During that period of time, U.S. commercial banks were losing competitiveness with respect to European ones.

Finally, The Riegle Neal Act was released in 1994. The act introduced many changes in the banking sector. It allowed Interstate expansion by Bank Holding (Interstate Banking) companies, subject to concentration limits. Thus, the Federal Reserve Board is prohibited from approving an interstate acquisition that would result in the holding company controlling more than 30 percent of the deposits held by insured depository institutions in a particular state, unless the host state eliminates the limitations entirely or has a lower concentration restriction. The Federal Reserve is also prohibited from approving an acquisition if, as a result, the bank holding company would control more than 10 percent of the total amount of deposits of insured depository institutions in the United States. Interstate branching, or the ability of banks to operate branches in more than one state was also permitted. Concentration limits were imposed also. However, the concentration limits in this case do not apply to any mergers of banks that are already affiliated. This would allow a bank holding company to consolidate its existing network of subsidiary banks into one bank with branches even when some of the existing subsidiaries have a market share larger than the limits.

\footnotetext{
${ }^{32}$ FIRREA restructured the savings and loan association regulatory system. It was enacted in response to the savings and loan crisis of the 1980s. This Act regulated the Capital by imposing that for every dollar purchase in asset, 10\% goes to Capital.

The St Germain act allowed emergency interstate acquisition of thrift institutions regardless of any state antibranching laws.
} 


\subsection{Calculation of efficiency indicators}

4.3.1 Methodology.

In this section we will explain how the efficiency scores are constructed. In addition, we describe the data sources and justify the use of certain variables to elaborate the efficiency scores.

The efficiency indicator has been calculated using the Data Envelopment Analysis (DEA) technique. In the past, average productivity of labor was used to measure efficiency but this indicator failed to use all the information of inputs and outputs available (see Farell (1957)). Cooper, Seiford and Zhu (2004) provide the following definition of 'relative efficiency' that solves the problem of the efficiency indicator used in the past:

"A DMU is to be rate fully efficient on the basis of available evidence if and only if the performances of other DMUs do not show that some of its inputs or outputs can be improved without worsening some of its other inputs or outputs".

Farrel (1957) introduced the basic idea of measuring relative efficiency using Euclidean distances from a given observation to an optimal 'relative frontier'. The word 'relative' is used because it is constructed based on sample information. A bank allocated on the frontier receives a score of one while banks allocated below the frontier get scores bigger than one. The idea can be visualized by looking at the figure below.

[Figure 4.1 about here]

The figure represents the case of two outputs and six decision making units: $\mathrm{P}_{1}, \mathrm{P}_{2}, \mathrm{P}_{3}, \mathrm{P}_{4}$, $\mathrm{P}_{5}, \mathrm{P}_{6}$ (DMUs). ${ }^{33} \mathrm{DMU}$ "P1" is efficient and, according to Farrel's distance method, it receives a score of one. This score is calculated by dividing two rays: the Euclidean distance from the

\footnotetext{
${ }^{33}$ In our case the DMU are banks but there are several studies analyzing efficiency of hospitals, colleges, departments, etc.
} 
origin to the optimal frontier (OC) divided by the Euclidean distance of the DMU "P1" to the origin (OC). DMU "P5" obtains an efficiency score higher than one because the Euclidean distance from the origin to the frontier is bigger than the Euclidean distance of DMU "P5" to the origin (i.e., $\mathrm{OB} / \mathrm{OA}>1$ ).

In the case of multiple inputs, outputs, and DMUs, efficiency scores are calculated using linear programming techniques. This methodology receives the name of DEA. Charnes, Cooper and Rhodes (1978) set up this linear programming that was not completely solved in the paper of Farrel (1957).

The linear program employed by Charnes, Rhodes and Cooper (1978) calculates the efficiency scores given by:

$\operatorname{Min} \varphi$

$$
\begin{aligned}
& \sum \lambda_{j} x_{i j}+S^{+}{ }_{i}=\varphi x_{i j_{0}} \\
& \sum \lambda_{j} y_{r j}-S^{-}{ }_{r}=y_{r j} \\
& S^{+}{ }_{i}, S^{-}{ }_{i} \geq 0 \\
& \lambda_{j} \geq 0 \\
& \forall i, j, r
\end{aligned}
$$

Where $x_{i j}$ is the amount of $\mathrm{i}^{\text {th }}$ input at DMU $\mathrm{j}, y_{r j}$ stands for the amount of $\mathrm{r}^{\text {th }}$ output from DMU j, and finally $j_{o} \quad$ is the DMU to assess. $S^{+}{ }_{i}, S^{-}{ }_{r}$ are the slack variables. ${ }^{34}$

The linear program is called input oriented model ${ }^{35}$ with constant returns to scale (CRS). ${ }^{36}$ The first restriction says that a DMU $\mathrm{j}_{0}$ cannot use more resources than any other DMU or a linear combination of DMUs. The second restriction means that no other DMU or combination of DMUs has at least the same amount of output as DMU $\mathrm{j}_{0}$. At the minimum $\varphi=1$

\footnotetext{
${ }^{34}$ See the paper of Charnes, Cooper and Rhode (1978) for a more complete explanation of this problem.

${ }^{35}$ There is another approach besides the input oriented model which is called output oriented model. The maximization of outputs is the dual of the linear program introduced by Charnes, Cooper and Rhode (1978).

${ }^{36}$ There are models that include Variable Returns to Scale (VRS) instead of CRS. VRS signifies that in a production process, the operations will follow increasing or decreasing returns to scale. Note also that, some firms that are not efficient in the models so far, may become efficient if we allow variable returns to scale assumption (relaxing the CRS assumption.)
} 
and $S^{+}{ }_{i}=S^{-}{ }_{r}=0$ for all $\mathrm{i}$ and $\mathrm{r}$. If at the minimum the slack variables are non zero, the solution is Weakly Efficient. Our estimation resulted in Fully Efficient, ${ }^{37}$ which means that the slack variables $\left(S^{+}{ }_{i}, S^{-}{ }_{r}\right)$ are zero at the minimum.

There are other ways of calculating measures of efficiency. Robert DeYoung (1997) and Chen (2001) calculated the efficiency of banks in the US system by introducing stochastic elements (Cost Efficiency Analysis). Authors like Berger and Mester (1999) used Profit Efficiency instead of Cost Efficiency because mergers of banks and technological changes negatively affected the results. We are aware of mergers and technological changes during the period in study. In section 3.3 we showed how our DEA scores are reliable and consistent which guarantee they are suitable in the study.

\subsubsection{Data description}

The inputs and outputs required for the DEA estimation are obtained from the Federal Reserve Bank of Chicago. It consists of annual observations from 1984-1997. The data is available for all banks regulated by the Federal Reserve System, Federal Deposit Insurance Corporation, and the Comptroller of the Currency. Information prior to 1984 is not reliable given that some institutions started updating their information in that year. The period of analysis ends in 1997, which is three years after the enactment of the Riegle Neal Act. According to the banking literature, changes in Bank Management can take up to three years to be reflected in the bank's indicators.

We incorporate all banks in the US financial statement. However we eliminate banks with financial statements in blank. The new sample consists of 14,320 banks for 1984 and 9,567 for 1997. The number of banks in the sample dropped from one year to another as result of mergers, acquisitions or failures.

\footnotetext{
${ }^{37}$ See these definitions in Cooper, W.W., Seiford, L.M. and Zhu, Joe (2004)
} 
Studies about bank efficiency use inputs and outputs according to the essential intermediary function of the bank. The model approximates the bank management decision making process by incorporating the necessary input allocation and product mix decisions needed to attract deposits and make favorable loans and investments. Mester and Berger (1997) and Barr, Killgo and Siems (1999) and other studies on bank efficiency use the same variables. ${ }^{38}$ Banks' inputs are interest expenses, non-interest expenses, salary expenses, premises and fixed assets and purchase funds (large deposits). Interest and non-interest incomes are considered banks' outputs. We did not include earning assets because there is no data available for this variable during the period under study.

\subsubsection{Data Envelopment Analysis estimation results}

[Table 4.1 about here]

Table 4.1 shows a summary of the DEA scores for the period 1984-1997. ${ }^{39}$ The indicators were rescaled by taking the reciprocal of the original estimation. Therefore, after rescaling the most efficient DMU receives a rescaled DEA score of one and the least efficient will receive a rescaled DEA score of less than one. We rescaled the scores of efficiency in order to get a better interpretation of the coefficient of the regressions.

In this way, if a bank has a DEA score of 0.80 , for example, it means that the bank is wasting $20 \%$ of the resources in order to produce a given output. ${ }^{40}$

In 1984, average efficiency in the US banking system, as measured by the average DEA score, was 0.331. Average efficiency decreased in 1989 to 0.118 . This result can be attributed to

\footnotetext{
${ }^{38}$ However, there are another approaches besides the intermediary approach used in this paper.

${ }^{39}$ To calculate the DEA scores and its bootstrapping, we have used the R program and the commands that Prof. Wilson (2005) has available on his web.

${ }^{40}$ The rescaling gives identical results to the output oriented model which is also the inverse of Shepard Distance Measures.
} 
the FIRREA Act of $1989,{ }^{41}$ which negatively affected the purchase of assets. ${ }^{42}$ During 1995 the DEA average score was 0.322 which is still low in comparison with the first period in study. This result may be the consequence of mergers. Big banks acquire smaller institutions but at the beginning, they incur some costs that disappear in the long run. (See Berger and Mester (2003))

The range of fluctuation of the score is quite large. The maximum value is one for 1984, and the minimum value is 0.118 , for the same period. In 1995 , the minimum score was 0.126 . The variability in the scores for some institutions can be attributed to outliers but we have confidence in our indicators because we run a test of difference in quartiles and we verify that there is a significant difference between the extreme quartiles. ${ }^{43}$ The evolution of the efficiency indicators by quartiles is shown in Figure 2. In addition, we run a Bootstrap ${ }^{44}$ for the first 340 banks and the ranking of the estimated scores do not differ with the simulated DEAs. Therefore, our efficient indicators can respond to sampling variations of the estimated frontier.

[Figure 4.2 about here]

Figure 4.3 shows average DEA scores by states for 1984 . We can see at first glance that on average some states are efficient in the North $^{45}$ but there are inefficient banks on average in the South. In particular, states like Maine, Connecticut, Rhode Island, New Jersey, Pennsylvania, South Carolina, Alabama and Delaware had the most efficient banks on average. The least

\footnotetext{
${ }^{41}$ FIRREA act of 1989, described in Section 2, was enacted to restructure the savings and loan association regulatory system.

${ }^{42}$ In the construction of efficiency's scores we consider as inputs the purchase of premises and fixed assets. FIRREA act of 1989 established that for every purchase of one dollar in assets 10 cents goes to capital. This situation may have affected the purchase of inputs and consequently our efficiency's scores.

${ }^{43}$ This guarantees reliability of our DEA scores because the efficiency scores show a consistent measure over the time.

${ }^{44}$ Bootstrapping is based on the idea of repeatedly simulating data generating process (DGP), by re-sampling and plugging the original estimator to each simulated sample so that the resulting estimates mimic the sampling distribution of the original estimator. We follow the Bootstrap commands posted by Wilson (2005).

${ }^{45}$ The classification of the regions by state comes from US Census Bureau. See table 4.1 for a detailed list of states by regions.
} 
efficient banks were located in North Dakota, South Dakota, Wyoming, Utah, Colorado and Idaho. States in the North, South and East or North and Southeast are the most efficient. The inefficient banks are primarily located in the Plains (Midwest and South West).

[Figure 4.3 about here]

The situation changed in 1997 and figure 4 shows how the efficiency indicators changes for this year, three years after the federal deregulation.

[Figure 4.4 about here]

The map changed and some states gained efficiency by comparing their DEA in 1984 against their score in 1997. States in the West, North and Midwest have become more efficient over time. This result will be analyzed in more detail in the next section.

\subsection{Empirical Model}

\subsubsection{Determinants of Bank Efficiency}

In this section, we test how efficiency is affected by the deregulation of the bank system. Our hypothesis is that deregulation improves efficiency. Figure 5 below shows that efficiency increased when the banks are deregulated regardless of location. We only show South and West because by 1989 the other two regions (North and Midwest) did not have any restriction to open branches outside the state.

[Insert Figure 4.5 about here]

In order to see the effects of the deregulation and the determinants of efficiency in a more detailed analysis, we run the following pooled regression:

$$
\begin{aligned}
& \text { DEA }_{i j t}=\beta_{0}+\beta_{1} \text { DEREGULATION }_{j t}+\beta_{2} \text { FIRREA }_{t}+\beta_{3} \text { DISCOUNT }_{t}+\beta_{5} \text { NORTH }_{i j} \\
& +\beta_{6} \text { MIDWEST }_{i j}+\beta_{7} \text { SOUTH }_{i j}+\beta_{9} \log (\text { ASSET })_{i j t}+\beta_{10} \text { YEAR_CONTROL }_{t}+\varepsilon_{i j t}
\end{aligned}
$$


The subindexes ' $i$ ', ' $j$ ' and ' $t$ ' refer to a particular bank, state, and time period. The endogenous variable (DEA) is the efficiency score previously estimated for each period and for each bank in the sample. DEREGULATION is a dummy variable that captures the release of branching restrictions. If state $\mathrm{j}$ relaxed law branching restrictions in period $\mathrm{T}$, this variable becomes 1 for every $t \geq T$, otherwise it is equal to 0 . For example, in 1986 Alabama established the interstate bank constraint. Then, for any bank in Alabama, the dummy DEREGULATION takes the value of one from 1986 onwards. By 1994 most of the states had released the branching restriction as shown in Table 4.2.

[Inserted Table 4.2 here]

According to our hypothesis, we expect this variable to be positive.

Spatial regional pattern of branching deregulation can be verified by observing Figure 6. The map indicates the year when states started to deregulate branching restrictions. Figure 6 shows that many states in the South and Midwest (mainly in the Plains area) deregulated the branching system after 1988, at the end while states in the West and Northeast deregulated earlier. The 'Special Interest' argument discussed by Kroszner and Strahan (1999), previously explained $^{46}$, may justify why the Plains area (Midwest and South West) was the last region to deregulate.

In order to determine whether a bank's location matters in terms of efficiency, North, South, Midwest and West regional dummies are introduced. The dummies are constructed from Table 4.3.

[Inserted Figure 4.6 about here]

\footnotetext{
${ }^{46}$ This "Special Interest" argument is introduced in section 1 and discussed in detail in section 2.
} 
The variable FIRREA is a dummy variable that takes the value of 1 from 1988-1997 for all banks. This dummy reflects the Federal Institutions Reform, Recovery and Enforcement Act of 1989. FIRREA was enacted to provide for the resolution of failed savings and loans institutions. This Act imposes some restrictions in the banks' assets and capital formation which are directly related to the construction of our DEA scores.

External macroeconomic factors also affect efficiency. In our model we control for discount rate (DISCOUNT). The latter indicator represents a good proxy of monetary policy. ${ }^{47}$ For instance, an expansionary monetary policy would reduce the bank cost and consequently increase efficiency.

The logarithm of assets reflects the effect of size on efficiency. If this coefficient is positive then, efficiency increases with the size of the bank.

We have included year dummies in order to capture a positive effect of technological changes.

The estimation of the regression is performed by using Newey-West Estimator. The estimator provides a general covariance matrix estimator that is consistent in the presence of both heteroskedasticity and autocorrelation of unknown form.

The variable assets and regional dummies are constructed from Table 4.3 and using the data taken from Federal Reserve Bank of Chicago. Each bank has a different physical address even though they can have the same name. For example, Wachovia has two branches and we are able to locate those for the same institution. This will facilitate our regional analysis in the paper. The Deregulation dummy is constructed according to Table 4.2 which is presented in Kroszner and Strahan's paper (1999). The data for discount rate is obtained from International Financial Statistics (2004).

\footnotetext{
${ }^{47}$ There is a consensus in the literature about how relaxed monetary policy help banks to reduce their costs. See Bernanke and Blinder (1992) also in Friedman and Schwarts (1963), Sims (1972) and Christiano and Ljungqvist (1988)
} 


\section{B. Results}

Table 4.4 shows two models. The first model considers internal and external factors and the second model considers regional effects. We will study next how bank failure is affected by regional factors, deregulation and internal factors.

Our panel is unbalanced because some banks disappear during the period under study due to mergers acquisitions or bank failure. The results in Table 4.4 indicate that the deregulation variable increased bank's efficiency. Branch deregulation improves efficiency no matter the location or size of the bank. The results support the efficiency argument proposed by the Opponents of branching restriction.

The Discount Rate has an expected negative role on efficiency. A high discount rate increases the banks' cost negatively affecting banks' efficiency. Chen, Mason and Higgins (2001) obtain similar results. Therefore, macroeconomic factors do have an influence on the banking system.

FIRREA seems to have reduced efficiency. The reason is that this act regulates the purchase of assets for more capital requirement. Purchase of assets is one of the inputs in the elaboration of DEA scores. Thus; FIRREA is producing a negative effect on banks' efficiency during the period of study.

Our results for model 1 indicate that bigger banks are more efficient because the variable $\log$ (Assets) is positively correlated to efficiency. Smaller banks were inefficient and this inefficiency increases when the bank is restricted to open a branch. For the second model the coefficient of $\log$ (assets) is not significant maybe because of the effect of regional dummies that are not controlled in comparison to model 1. 
In relation to the last result, Figure 4.7 shows how the distribution of "small banks"48 varies across the regions and we verify that $73 \%$ of these "small banks" are located in the South and Midwest. The special interest argument may explain why some small banks located in the Midwest and South were in favor of branching restriction and, as we discussed in the preceding section, these regions were the last ones to deregulate.

[Inserted Figure 4.7 about here]

The dummy for the South does not give any significant coefficient. The dummy for North and Midwest have a negative impact on efficiency. Banks located in these areas have a lower efficiency relative to the West. The results support the fact discussed in 4.3, when we discussed how banks in the West deregulated earlier in comparison to South and Midwest. The early deregulation of banks from the West may help them to be relative efficient in comparison to other regions.

For the Year dummies, we found that there are some positive significant effects on efficiency in particular during mid 90's.

\subsubsection{Bank Bankruptcy Analysis}

In this section, we examine the causes of bank failures in the U.S. during 1984-1997. This period is particularly interesting to analyze because at that time most states passed laws relaxing branching restrictions.

[Figure 4.8 about here]

Figure 8 shows a very interesting preliminary result. Most of the banks that failed during the eighties were located in the South and Midwest. In 1984, eighty-five banks located in these

\footnotetext{
${ }^{48}$ We consider a bank small if it has less than US\$ 100 millions in assets $(1996=100)$.
} 
two regions failed and this number increased to seven hundred and forty in 1989. Another interesting result is that over most part of the period, banks located in the North failed less in comparison with those in other regions. Maybe the agreement in the North which Tart (1995) refer to reduced the number of failing banks in the region. ${ }^{49}$

One possible explanation of why banks in the South failed more over the time in study is provided by Kroszner \& Strahan (1999) and Garret, Wagner \& Wheelock (2004) They argue how "special interest" groups affect the decision of a bank to opt for a restriction to open a branch. They claim that, small banks in the South and Midwest might have an interest to avoid the entry of large banks that can drive them out of the business. The regional "special interest" explained by Koszner and Strahan (1999) could have induced them to loosen competitiveness and make them fail. We will verify with a Logit Model whether most of the banks in the South and Midwest were more exposed to failure relative to other regions.

Again by just looking at the data, we find that most of the banks that failed are those with assets smaller than US \$100 millions (see Figure 3.9). The big banks were less exposed to failure. In 1984, there were 107 failing financial institutions with less than US \$100 millions in contrast to zero failing banks with assets bigger than US $\$ 400$ millions. A similar situation is observed in the following years. The latter observation indicates that the probability of failure should be smaller for big banks.

In 1984 there were 14,320 banks in total, but the number is reduced to 9,567 in 1997 . Merger and acquisitions are very difficult to analyze individually. However, the failure of banks as a consequence of the deregulation or due to the banks' internal factors will be analyzed using a Logit model.

\footnotetext{
${ }^{49}$ We explain in section 2 how the states in the North tried to avoid the negative effect of branch regulation by making reciprocal agreements which allow banks to open branches in the states that belong the agreement.
} 
In order to obtain the most accurate analysis in the Logit Model, ${ }^{50}$ we clean the data of banks acquired or merged in order to avoid any selectivity bias in the estimation ${ }^{51}$. The new data contains banks that never fail from 1984-1997, or banks who failed and could not get acquired or merged. $^{52}$

Bank's health has been evaluated using the Capital adequacy, Asset quality, Management quality, Earning ability, and Liquidity position ratio (C.A.M.E.L.). However, the assessment of management quality introduces some difficulties into the analysis. The most important problem consists of measuring management quality. The assessment of management quality would require good professional judgment of the bank's compliance to policies and procedures, risk taking, strategic plans, and decisions.

In this paper, we consider DEA scores as proxies of management quality. We assume that efficiency scores should be able to identify whether the bank is processing multiple input-outputs in an efficient manner.

For capital adequacy, we use capital as a ratio of asset. This variable has been extremely important in the explanation of failures in the US system. Authors like Altman (1968) and Shumway (2001) proceed in a similar way. Mishkin and Eakins (1999) also point out the importance of this variable. A drop in the ratio of capital divided by assets would force bank insolvency.

For asset quality, we use nonperforming loans (NPL) as a ratio of assets. Most of the literature considers this variable as a good proxy of asset quality because when most loans are

\footnotetext{
${ }^{50}$ A Logit Model is implemented to calculate the probability of failure. Economists and financial analysts have been analyzing the determinants of bankruptcy for decades (Altmann (1993)). Logit and Probit models have been used by banks' examiners to predict bank failure (see Martin (1977), Hanweck (1977) and Pantalone and Platt (1987)). We use Logit Models in this case in order to avoid convergence problems caused with Probit models. In some cases there are ranges where we cannot define probabilities. Therefore, a Logistic Model is very useful and popular in the banking literature.

${ }^{51} \mathrm{We}$ do not consider banks acquired or merged because they are not failing institutions. The new data is able to replicate a peak in the number failure of failing institutions during 1989 (see Figure 4.8 and 4.9). This is consistent with the banking crisis in the US mentioned in 4.4.

52 We use a definition of failure that comes from FDIC and states that in a Failure, entity ceases to exist. Resolution was arranged by the FDIC, RTC, NCUA, State or other regulatory agency.
} 
bad and assets are dropping, it poses a considerable problem for the bank. It is widely accepted that banking failure can be explained by this variable.

We use profits as a ratio of Capital, to proxy earning ability, which is the typical return to Capital (ROE) indicator. The measure is used by Martin (1977), Wilson and Wheelock (2000), and others. A higher ratio of profits as a ratio of Capital reduces the likelihood of failure.

For liquidity, we use loan as a ratio of deposits. This indicator reflects the ability to support loan growth with deposits. Deposits are the main way to fund their loans and operations. Higher values of this ratio imply that there are fewer additional deposits to fund loans, implying lower liquidity which increases the likelihood of failure.

The dummy FAIL takes a value equal to one three years before a bank fails and zero otherwise. This is standard procedure followed in the literature. It has been used for example by Martin (1977) and Pantalone (1987).

The variable DEREGULATION is introduced here to determine whether deregulation increases or reduces the probability of failure. Following the argument of portfolio diversification discussed in section 4.2, we may expect this variable to be negative. The proponents of branch banking believe that the release of the branching restriction reduces the risk diversification in bank portfolio and improves the quality of loans. Consequently, we should expect a reduction in the bank's failure when deregulation of branch restriction comes up. ${ }^{53}$

Regional effect is considered by adding dummies for each region of the U.S. The Year Control is a dummy that control for some structural changes from 1984 to 1997.

Considering all the variables, the Logit regression becomes:

$$
\begin{aligned}
& \text { FAIL }_{i j t}=\beta_{0}+\beta_{2} \text { DEA }_{i j t}+\beta_{6}\left[\text { CAPITAL }_{i j t} / \text { ASSET }_{i j t}\right]+\beta_{7}\left[N P L_{i j t} / \text { ASSET }_{i j t}\right]+ \\
& \beta_{8}\left[\text { PROFIT }_{i j t} / \text { ASSET }_{i j t}\right]+\beta_{9}\left[\text { LOAN }_{i j t} / \text { DEPOSIT }_{i j t}\right]+\beta_{1} \text { DEREGULATION }_{j t} \\
& +\beta_{3} \text { NORTH }_{i j}+\beta_{4} \text { MIDWEST }_{i j}+\beta_{5} \text { SOUTH }_{i j}+\beta_{10} \text { YEAR_CONTROL }_{t}+\varepsilon_{i j t}
\end{aligned}
$$

\footnotetext{
${ }^{53}$ There is not a study in the literature that analyses the direct impact of deregulation on bank's failure.
} 
The error term $\varepsilon_{i j t}$ is assumed to be normally distributed with the respective properties of white noise.

\section{A. Results}

The results of the Logit Estimation are shown in Table 4.5. The four models can predict correctly in overall $92.8 \%, 93.8 \%, 92.9 \%, 93.9 \%$ observations respectively. This means that the failure predictions of the models are quite accurate.

The pooled estimation does not show any significant coefficient for the DEA scores (in Model 1 and 3). However, the DEREGULATION variable shows a negative sign in Models 2 and 4. It implies that failure decreased with the release of branching restrictions. The result goes along the line of Ennis (2004), ${ }^{54}$ who claims that changes in bank regulation during the 80 's decreased the risk exposure of banks.

The magnitude of the deregulation effect is shown in Table 4.6. The marginal effect of this variable is -0.753 for the second model and -0.812 for the last model. ${ }^{55}$ The differences between the models are explained by the regional dummies which are included only in the last $\operatorname{model}^{56}$

All the variables from the C.A.M.E.L are significantly different than zero and have the correct sign. The marginal effect for Capital/Asset was negative, which means that the higher Capital as a ratio of Assets implies a reduction in the risk of failure. The shares of nonperforming loans gave the right sign which means that good asset quality reduces the probability of failure.

The Profits as a ratio of capital gave the expected negative sign as well as the inverse of the variable Loan/Deposits. We rescale by taking the inverse of Loan/Deposits in order to get a coefficient comparable with the other variables. The negative coefficient of the inverse of

\footnotetext{
${ }^{54}$ Ennis (2001) also states that branching deregulation induced banks to face a trade off between higher operating costs and improvements in the loan portfolio.

Also, Ennis and Malek (2005) show how big banks tend to reduce its probability of failure after branch deregulation.

${ }_{55}^{55}$ See table 4.5 for further details.

${ }^{56}$ The results give the same sign even if we consider a dummy FAIL within one year and two years before failure.
} 
Loans/Deposits implies that higher deposits support loans and therefore reduces the probability of failure.

Models 3 and 4 show the results for the Dummy variables. The Midwest and South variables have a positive and negative sign respectively. It means that a bank located in the Midwest has a higher probability of failure with respect to another in the West. The Dummy for the North was not significant but shows that a bank located in the North decreases its probability of failure with respect to the West. Regional agreements in the North may have helped this result.

\subsection{Conclusions}

When the restriction for opening a branch or subsidiary was released, banks were able to improve their efficiency. This result differs from DeYoung (1998) in the sense that everybody suffers at the same level and there were not any banks exempt from inefficiencies as a consequence of deregulation.

The inefficiency of many U.S. banks was overcome by state deregulation, which ended up with the enactment of the Act of 1994. In addition, banks in the South and Midwest were more inefficient in absolute number than those in the North and West region. The North region made agreements among themselves to avoid the negative consequences of the McFadden Act (1956). These agreements could have neutralized the reduction of inefficiency and consequently reduced to zero the probability of failure in that particular region.

The deregulation can explain the feature that U.S. Banks became more competitive, even when compared to European Banks. Mulloy (1995) cites the fact that in 1983, three U.S. commercial banks were among the world's top twenty in asset size and by the end of 1988 no U.S. bank was ranked among the world's top twenty.

"Special interest" groups may have played an important role in the South and Midwest (Plains area). Politicians from that part of the country were trying to restrict the entry of big 
banks in the region. This may have produced a negative effect in the performance of the US banks. Bank Competition became more important and the Riegle Neal reflected the necessity to homogenize the branch deregulation which started in 1970.

The paper is relevant in terms of regulation of U.S banks. Institutions that regulate the banking system could consider this analysis to avoid the risk of intervention and maybe spend almost the full amount of the banking insurance. 


\section{Chapter 5}

\section{Lending Practice Outcomes of Large and Small Banks}




\subsection{Introduction}

De Young and Berger (1997) describe four different hypotheses that could potentially establish a link between non-performing loans (NPL hereafter), efficiency, and the financial structure of a bank. The hypotheses were given the following names: (i) "Bad Luck"; (ii) "Bad Management"; (iii) "Skimping"; and (iv) "Moral Hazard”. De Young and Berger (1997) used a Granger causality test to verify these hypotheses.

The purpose of this paper is to test these four hypotheses and also be consistent with the statistical behavior of the variables over time. In addition, our study split banks by size. DeYoung and Berger (1997), on the other hand, analyze their hypotheses in the period 19851994. We consider three different periods in our study. The first one starts in 1985-94, the second one starts in 1994-2005, and the last sample goes from 1985-2005. We also intend to determine whether whether the behavior of banks changes over time.

There are several papers that explain the proportion of NPLs held by banks. Lu, Thangavelu and $\mathrm{Hu}$ (2001), and Bloem and Gorter (2001), for example, examine the effect of different bank's policies on NPL. The first one focuses on the statistical treatment of NPLs. The second one uses a panel data set of public listing companies in China to explore the relationship between banks' lending behavior and NPLs.

Demirguc-Kunt (1989), Whalen (1991) and Barr and Siemens (1994) analyze how failure is related to asset quality. They found a relationship between low shares of NPL, high efficiency and low probability of failure.

Authors like Stein (2004), Keeton (1995) and DeYoung, Goldberg and White (1997) consider that small and large banks behave differently. In particular, Stein (2004) explores the idea that small organizations may have a comparative advantage in activities that make heavy use of "soft information". In the context of bank lending, large banks are less willing to lend to 
small firms with no financial records. In contrast, small banks are able to do it because they can personally interact with borrowers. Petersen and Rajan (1994) analyze small business lending and show how the distance between small firms and their lenders have increased with a substantial development of the financial sector even in small business areas. The availability of credit for small businesses is based on the close relationship with their creditors.

We will try to analyze if the heterogeneous banking lending practices followed by banks of different size affect the inter-temporal relationship of shares between NPL, efficiency, and capital (as a proportion of the banks' assets). In addition, by comparing different periods, our study will verify if external factors, as banking deregulation, may affect large or small banks' performance over the time periods under study.

The paper is organized as follows. Section 4.2 provides a brief discussion of theory on NPLs. Section 5.3 presents a discussion about different lending practices followed by banks of various sizes. Section 5.4 presents an overview of the banking system and Section 5.5 introduces the methodology employed to calculate banks' efficiency and shows the results. Section 5.6 section presents the pool model, Section 5.7 shows the estimations, and the last section concludes.

\subsection{The four Hypothesis about Problem Loans and Efficiency}

We examine the four Hypotheses of DeYoung and Berger (1997), but following a different approach.

The "Bad Luck" hypothesis stated by DeYoung and Berger (1997) refers to external events which are out-of-management factors. The bank incurs in additional expenditures (basically monitoring costs) to face those external events, so NPLs rise as a result of the increase in expenditures (monitoring costs). The hypothesis can be empirically verified if the data shows a negative Granger Causality from NPLs to efficiency. In other words, a higher amount of NPLs reduce efficiency. The latter would be observed because when a bank faces an exogenous 
increase in NPLs, it will purchase additional inputs necessary to administer the credit problem itself. This higher cost for the bank is associated with higher NPLs.

Just as a caveat, if we consider as a starting point a decrease in NPL, the negative relationship established under this hypothesis will permit to infer that efficiency may increase. The NPL does not show an increasing or decreasing trend over time (see Figure 5.1) therefore it is not sure that the causality is a like a Bad Luck. The authors consider the negative causality from NPL to Efficiency as "Bad Luck".

The "Bad Management Hypothesis" implies a negative relationship between efficiency and shares of NPL. "Bad Management" occurs when low efficiency is a signal of poor senior management practices, which applies to the day-to-day operations and the management of the portfolio. So, low efficiency, or simply inefficiency, occurs before high NPLs. Note that this is just the opposite causality considered in the "Bad Luck" hypothesis. However, again as a caveat, we can consider the case when efficiency increases the negative causality will state a decrease in NPL. The authors consider a negative causality from Efficiency to NPL as "Bad Management".

Under the "Skimping Hypothesis", the amount of resources allocated to underwriting and monitoring loans affects both loan quality and cost efficiency. There is a trade-off between short run operating cost and future loan performance. A maximizing- profit bank may rationally choose to have lower costs in the short run by "skimping" on the resources devoted to underwriting and monitoring loans, but bear with bad loan performance problems and the possible cost of dealing with these problems in the future. In this case, there is a positive Granger Causality from Efficiency to NPLs. In order to test this hypothesis, DeYoung and Berger (1997) consider a sub-sample of banks with a score of efficiency above the average to capture the skimping banks. Banks with an efficiency score above the average for every year in the sample is considered. The sub-sample can keep a record of banks that are suspicious to be skimpers or efficient in the long run. 
The "Moral Hazard" hypothesis is the classical problem of excessive risk-taking when another party is bearing part of the risk and cannot easily charge for or prevent that risk-taking. In this case, there is a negative Granger Causality from capital to NPLs. Banks with low capital respond to moral hazard incentives by increasing the riskiness of its loan portfolio, which results in higher NPLs in the future.

The hypotheses are not mutually exclusive. They attempt to explain changes in NPLs. The next section presents an explanation of different bank's lending practices.

\subsection{Review of Bank Lending Practices by bank's size}

Stein (2004) studies the banking industry and attempts to answer the following question: Does the nature of a financial organization affect both their efficiency and lending?

Small banking institutions have comparative advantage in evaluating investment projects with "soft" information that cannot be easily communicated from one agent to another in the bank. ${ }^{57}$ The loan officer of the small bank is usually the president of the institution and does not need to evaluate credits through a bureaucratic system as observed in bigger banks.

Large banks, in contrast, manage "hard" information more easily. They evaluate the credits within a strict hierarchy. "Hard" information means that authorities of a large bank process the credits with some strict (hard) credit scores and then pass the report to their superiors. Therefore, it makes more difficult to get a credit from a large bank and it is very difficult for a large bank to do a deep research of the surrounding area.

Stein (2004) suggests that large banks tend not to lend to small business institutions because their activity relies on the production of "soft" information. ${ }^{58}$ Some small businesses do not audit frequently their financial statements and this "soft" information had not been approved

\footnotetext{
${ }^{57}$ Stein (2004) defines soft information as the research that a loan officer does. The research is based on the economic activity of local business firms. This research can be commanded better by the small banks.

58 Berger and Udell (2002) study the dichotomy between hard and soft information but using a different terminology. He introduces the concept of "relationship" lending versus "transaction based" lending. Large banks have advantage when it comes to "transaction based" lending and the small institutions manage better the "relationship" lending.
} 
by the first loan agent of a large bank. If the information were well documented, tracked and monitored, then the credit would be extended and approved by several loan agents in large banks.

Stein's paper (2004) states that the loan research in small banks are more intensive than large. In small banks, the authority to allocate the credit is separated from expertise in a large bank. Large banks look for risk less lending opportunities without much investment in research.

Small and Large banks have different Lending Practices. However their performance can be similar at the end. Small banks were able to survive over time and they lend successfully in areas where large banks are not capable of doing so. The heterogeneity in the lending practices would not affect the internal performance of banks in terms of efficiency, NPLs and capital ratios. We will test if the hypotheses have changed by bank's size and over time.

\subsection{Overview of the Banking during 1984-2004}

Different external factors, such as banking deregulation, may have affected banks' lending practices, and, consequently, the hypotheses stated before may not explain banks' behavior throughout the whole period. ${ }^{59}$ The US banking system had banned branching diversification during a long period of time. The MacFadden Act of 1927 was enacted in reply to some requests from some interest groups. These interest groups were in favor of branching restrictions (see Kroszner (1999) and Garrett, Wagner and Wheelock (2004)). The proponents of branching restrictions believed that bank branching restrictions will alleviate the banking concentration and avoid a situation where money can be drained away from local communities to other places. The Riegle Neal Act in 1994 deregulated the branching restriction, but state laws effectively deregulated banking activities a few years before the enactment of the federal law. The deregulation of the banking system produced some consequences in the bank's performance.

\footnotetext{
${ }^{59}$ In fact, our paper will attempt to determine whether the same hypotheses can be used to explain banks' behavior throughout the period 1984-2004.
} 
Ennis (2004), for example, shows that during the period of bank deregulation (1980s) there was a reduction in the risk exposure of banks. However, for this author there is a latent banking concentration concern. It means that banks are not overcoming the main problems before and after the enactment of branching deregulation. Thus, either internal factors of the bank, like Bad Management and Skimping, or external factors, such as Bad Luck, may not have changed over time.

In 1994, branching deregulation became federal. DeYoung and Berger (1997) used a sample from 1985-1994. We are considering three different samples from 1985-1994, 1995-2005 and 1985-2005. We will contrast our results with DeYoung and Berger's.

Financial Institutions Reform, Recovery, and Enforcement Act of 1989 (FIRREA Act) is also introducing impacts in the banking system. The FIRREA Act restructured the savings and loan of banks with a regulatory system. It was enacted in response to the savings and loan crisis of the 1980s. The Act regulated bank's capital by imposing that for every dollar purchase in asset, $10 \%$ goes to capital. Akhigbe (2001) claims that the contagion effects of bank failure are less pronounced in the period following the passage of FIRREA. Banks with high capital are less exposed to failure. Jahera (1995) found significant and positive effects on banks' wealth after the enactment of FIRREA.

It seems that the FIRREA act may affect Moral Hazard hypothesis explained in previous section because, this act changes capital requirement. However, if we consider the merging process of banks, large institutions acquire smaller and their losses. Contrary to the literature, it may be that FIRREA had not changed the banking situation due to the merging process and banking consolidation in the nineties.

The inter-temporal relationship between shares of NPL, efficiency and capital would not have changed over the time. External Factors like FIRREA Act of 1989, or the Riegle Neal Act 
of 1994 could have affected symmetrically to all the banks. We can verify in Ennis (2004) that there is still a latent problem of bank's concentration and failure.

The next section presents the methodology that will be used to determine whether there is a structural change in the inter-temporal relationship between the share of NPL, efficiency and capital. Our study will analyze which of the hypothesis introduced earlier can explain bank behavior for different time periods and bank size.

\subsection{Estimation of the Efficiency}

\section{A. Methodology and Data}

In this section we explain how efficiency is estimated. The literature of productive efficiency began in the 1950's with the work of Koopmans (1951), Debreau (1951), and Shepard (1953). Koopmans provided a definition of technical efficiency:

A producer is technically efficient if, and only if, it is impossible to produce more of any output without producing less of some other output or using more of some input.

Farell (1957) introduced distance functions as a way of measuring the radial distance of a producer from an optimal production frontier. Charnes, Cooper and Rhode (1978) provided the procedure to estimate scores of efficiency following Farell methodology. The procedure is called Data Envelopment Analysis (DEA). In this procedure, the banks minimize the choice of inputs given outputs. The dual program produces identical results. This linear programming method obtains a frontier formed by the most efficient banks.

DEA is a non-parametric and non-stochastic technique. Our methodology to estimate efficiency is a stochastic technique which used most frequently in the literature due to its easier estimation. ${ }^{60}$ Our methodology is also under the framework of Stochastic Frontier Analysis which includes production frontier, profit efficiency and cost efficiency methods (Kumbhakar and Lovell (2000)).

\footnotetext{
${ }^{60}$ DeYoung and Berger (1997) used this approach to estimate bank efficiency in their paper.
} 
The Stochastic Frontier Analysis was attributed to Meeusen and Broeck (1977) and June, Aigner, Lovell and Schmidt (1977). They used this methodology to calculate efficiency with production frontier models. However, De Young and Berger (1997) calculated an operating cost frontier to capture technological changes. They obtained scores of cost efficiency from the following specification: ${ }^{61}$

$$
\begin{aligned}
& \ln O C_{i t}=\alpha_{0}+\sum_{j=1}^{5} \beta_{j} \ln Y_{i j t}+(1 / 2) \sum_{j}^{5} \sum_{k}^{5} \beta_{j k} \ln Y_{i j t} \ln Y_{i k t}+\sum_{m}^{2} \gamma_{m} \ln W_{i m t}+(1 / 2) \sum_{m}^{2} \sum_{n}^{5} \gamma_{m n} \ln W_{i m t} \ln W_{\text {int }}+ \\
& (1 / 2) \sum_{j}^{5} \sum_{m}^{2} \rho_{j m} \ln Y_{i j t} \ln W_{i m t}+\sum_{j}^{7}\left[\delta_{j} \cos Z_{i j t}+\phi_{j} \operatorname{sen} Z_{i j t}\right]+\sum_{j=1}^{7} \sum_{k=j}^{7}\left[\delta_{j k} \cos \left(Z_{i j t}+Z_{i k t}\right)+\phi_{j k}\left(\operatorname{sen} Z_{i j t}+\operatorname{sen} Z_{i k t}\right)\right]+ \\
& \sum_{j=1}^{7} \sum_{k=j}^{7} \sum_{l=k}^{7}\left[\delta_{j k l} \cos \left(Z_{i j t}+Z_{i k t}+Z_{i l t}\right)+\phi_{j k l}\left(\operatorname{sen} Z_{i j t}+\operatorname{sen} Z_{i k t}+\operatorname{sen} Z_{i l t}\right)\right]+\lambda_{L} \text { Limit }_{t}+\lambda_{U} U n i t_{t}+\eta_{i t}
\end{aligned}
$$

The equation above is also called a Fourier-flexible form. ${ }^{62}$ In this paper, we use the inputs and outputs that DeYoung and Berger (1997) used. Banks' input is operating costs (OC). Commercial loans, consumer loans, real state loans, transaction deposits, and fee-based income are the five bank's outputs $\left(\mathrm{Y}_{\mathrm{j}}\right)$. We also included two inputs prices which are the price of labor and physical capital $\left(\mathrm{W}_{\mathrm{m}}\right)^{63}$

The variables Limit and Unit are dummy variables equal to 1 for banks in states that restricted or banned branch banking during the observed year. ${ }^{64}$

The values of $Z_{j}$ are functions that rescaled $Y_{j}$, so that they fall in the interval $[.1 * 2 \Pi$, $.9 * 2 \Pi]$. The rescale is also used in Berger, Leusner and Mingo (1994). ${ }^{65}$

\footnotetext{
${ }^{61}$ We will use this approach in our estimation of efficiency.

${ }^{62}$ The Fourier-flexible form can globally approximate and guarantee convergence with the help of the trigonometric terms (see Berger, Leusner and Mingo (1994)).

${ }^{63}$ Price of labor is obtained by dividing salary by number of employees. Price of capital comes from the ratio of expenditures on equipment and premises divided by the book value of physical assets. The variables are constructed in the same way by DeYoung and Berger (1997).

${ }^{64} \mathrm{We}$ construct these dummies according to the table of deregulation of states by year which is presented in Kroszner and Strahan (1999).

${ }^{65}$ Basically $\mathrm{Z}_{\mathrm{i}}=0.2 \Pi-\mu \mathrm{a}+\mu \ln \mathrm{Y}_{\mathrm{i}}$, where $[\mathrm{a}, \mathrm{b}]$ is the range of $\ln \mathrm{Yi}$ and $\mu=(0.9 * 2 \Pi-0.1 * 2 \Pi) /(\mathrm{b}-\mathrm{a})$
} 
The term error term can be divided in two parts: Ln U and Ln V. The first term captures cost inefficiency of the bank. The $\ln U$ has a truncated positive normal distribution. The $\ln V$ is a random error and has a symmetric normal distribution.

In a first step, we calculate the values of the coefficient of the Fourier flexible form regression. In a second step, we calculate the expected value of $\ln U$ conditional on the previously estimated values of the residual $\eta{ }^{66}$ For each bank $i$ and for every year $t$, cost efficiency scores are equal to the ratio of the most efficient bank (minimum $\mathrm{U}$ ) at time $t$ divided by the estimated value of $\mathrm{U}$ for bank $I$, i.e., $\left(\mathrm{U}_{\mathrm{min}, \mathrm{t}} / \mathrm{U}_{\mathrm{i}, \mathrm{t}}\right)$. Cost efficiency score varies between 0 and 1 .

The data employed in our calculations was obtained from the banks' financial statements. The data is available on the Chicago Fed web. The Chicago Fed publishes the financial statements quarterly. There are in average, for each year, ten thousand banks providing their information. The next section presents the estimation results of the cost efficiency measures for all banks between 1985 and 2005.

\section{B. Results}

Efficiency indicators for each bank in the sample are computed following a Stochastic Frontier approach. We estimate the efficiency for all the banks in US. Table 5.2 shows a summary of statistics of our efficiency estimations by period. On each period, we indicate the number of banks mean, maximum and minimum scores of efficiency.

[Insert Table 5.2 here]

On average, banks show an efficiency score of 0.1513 in 1985 and the score drops to 0.1345 in 2005 . There is a pick of 0.26 in efficiency during 2001 , which can be attributed to

\footnotetext{
${ }^{66}$ For a detailed explanation of the calculation of cost efficiency see Kumbhakar and Lovell (2000)
} 
external factors like technology shocks in the banking system (See Berger and Mester (2003) for a better description). The next section explains the factors that affected efficiency.

In addition, 5,789 banks disappeared from 1985 to 2004. After 1997 the number of institutions that disappear decreased, but there are still some institutions that either fail or merge. This situation can affect our hypothesis testing over different periods of time. The next section discusses how we split the sample by bank size and time periods.

\subsection{Panel Model}

\section{A. Data}

Our data goes from 1985 to 2004 . We split the sample in two sub samples. The first one covers the period 1985-1994. This is the same sample that Berger and DeYoung (1997) used to test the four hypotheses described before. The second sub-sample covers the period 1995-2005. We use this sample because we are interested in determining whether the same hypotheses explain bank behavior in a different macroeconomic context.

We are also interested in examining if banks behave differently by sizes. Thus, we split the sample in two groups containing small and large banks. The first group includes banks with assets less than US\$50 millions of dollars. ${ }^{67}$ The second group contains large banks with assets bigger than US\$ 50 millions of dollars. We are interested in how the four hypotheses discussed in previous section changes within banks' sizes and over the two sub samples considered in the preceding paragraph.

\section{B. Model Specification}

We use the previously estimated efficiency scores to check the four hypotheses that are assumed to describe banks' behavior. In section II, we establish a unique Granger Causality order and signed relationship between variables. This relationship will allow us to determine

\footnotetext{
${ }^{67}$ The dollars are expressed in real terms with base year $(2005=100)$. We can see from figure 5.2 that there is a threshold in the distribution of banks around US $\$ 50$ millions $(2005=100)$.
} 
which of the hypotheses set up before hold. The following panel regressions test a Granger Causality between the variables:

$$
\begin{gathered}
N P L_{i, t}=\alpha_{1}+\sum_{j=1}^{4} \alpha_{j+1} \text { EFFICIENCY }_{i, t-j}+\alpha_{6} \text { Year_Control }+\varepsilon_{i, t} \\
\text { EFFICIENCY } Y_{i, t}=\beta_{1}+\sum_{j=1}^{4} \beta_{j+1} N P L_{i, t-j}+\beta_{6} \text { Year_Control }+\varepsilon_{i, t} \\
N P L_{i, t}=\gamma_{1}+\sum_{j=1}^{4} \gamma_{j+1} C_{-} A P_{i, t-j}+\gamma_{6} \text { Year_Control }+\varepsilon_{i, t}
\end{gathered}
$$

where:

NPL : nonperforming loans as a percentage of total loans;

EFFICIENCY : efficiency as measured by the efficiency scores calculated in Section V;

CAP : capital as a ratio of assets.

Year_Control : Dummies for years ${ }^{68}$

The previous specification was chosen because it is similar to the one formulated by Berger and De Young (1997). ${ }^{69}$ According to the relationship discussed in section 4.2, the first equation tests for Bad Management, the second for Bad Luck and Skimping, ${ }^{70}$ and the last one for Moral Hazard.

Our study will allow us to examine banks' performance by bank size and contrast their behavior for the two time periods considered earlier.

We check for Granger causality between the variables ${ }^{71}$, and, then later, we verify the sign of the relationship in the set of equations provided above. The sign is given by adding the

\footnotetext{
${ }^{68} \mathrm{We}$ are trying to control for omitted variables that change over the time but are constant between cases.

${ }^{69}$ One difference is that DeYoung and Berger (1997) construct the variable of Risk as a control variable for their empirical analysis. We are trying to run the causality test in almost the same way they did.

${ }^{70}$ In this case, any of the hypotheses will hold depending on the sign of causality between efficiency and ratio of NPL. For the Skimping hypothesis we consider banks with efficiency score above the mean of 1984. Berger and DeYoung (1997) used this sub sample of high efficiently banks to test for skimping.

${ }^{71}$ The Granger Causality test the null hypothesis of X does not cause Y. The null hypothesis check for the significance of the coefficients for X. In our case the variables to be tested are Shares of Loan, Shares of Capital and Efficiency.
} 
value of the coefficients of each lag for any specific variable. We used four lags in our analysis. The addition of a fifth lag is irrelevant because they resulted non-significant in the Granger causality test. There is also a consensus in the literature that banks take up to three years to show structural change in management after any financial policy is released.

\subsection{Results}

We follow the rules established theoretically in Section 5.2 to accept or reject the four hypotheses: Bad Management, Bad Luck, Skimping and Moral Hazard. We consider size effects under different samples.

Table 5.5 summarizes our finding from the Granger Causality tests detailed in Tables 5.25.5. For the whole bank system during 1985-1994, we found Bad Management, Bad Luck, Skimping and Moral Hazard. These results are the same like DeYoung and Berger (1997).

For the whole bank system during 1995-2005, again all the hypotheses hold. It means that we could find Granger-causality between shares of NOL, Capital and Efficiency (described in 5.2). An explanation of the results can be found in Ennis (2004), who claim that banks are more profitable now, but they participate in riskier activities. The banking problems are latent besides the different periods in consideration.

For the total system of banks and the period 1985-2005 we accept all the hypotheses as well as in the other sub periods. The banks are equally affected by the hypotheses during the periods 1985-1994 and 1994-97. The turbulent period 85-94, where most of bank deregulations occurred, such as FIRREA and the Riegle Neal Act of 1994, had the same results as in the period without banking deregulations (95-2005).

The period 1985-1994, as explained before, was a period characterized by many banks' failures relative to 1995-2005. There were also several mergers and acquisitions. In addition, we discussed in section 5.4 that FIRREA and Riegle Neal were enacted to overcome the loans and 
saving problems. According to our results the Acts are not producing any effects on the hypotheses in assessment.

Ennis (2004) claim that after Riegle Neal there is a problem of bank concentration in the system and there is an increase risk of big financial institutions. The situations describe by Ennis (2004) support our results because the system of banks in the US have not overcome the problems of Bad Luck, Bad Management, Skimping and Moral Hazard studied in our paper.

Table 5.2 also summarizes the results for banks of different size along time. We find that small and large banks are affected by Bad Luck, Bad Management, Skimping and Moral Hazard during 1985-1994 and also for the period 1995-2005. The turbulent period of deregulation affected small and large banks and they were not able to reverse the situation during 1995-2005.

Large banks, or size 2, banks are affected are affected by Bad Luck, Bad Management, Skimping and Moral Hazard during 1985-1994 and 1995-2005. The result contrasts Ennis (2004) who claims that large banks do not need to add capital because they diversify better the portfolio across their branches. Small banks, in his paper, are always affected by Moral Hazard because of the decreasing economies of scale. We find that Large and Small banks need to add more capital to reduce the risk of an increase in NPL.

Small banks behave inimical different than larger banks. Smaller institutions are less bureaucratic and manage soft information better by having better personal relationship with their customers. They are more patient and the distance with their customers is shorter in comparison with large banks (see, for instance, DeYoung, Goldberg and White (1998)). However, the heterogeneity on lending practices followed by banks of different size does not affect the intertemporal relationships between shares of NPL, efficiency and capital during our periods of study. Our periods in study are characterized by an environment with or without significant regulatory changes. 


\subsection{Conclusions}

The fulfillment of the four hypotheses does not change across time and bank size. For the first period in our study that goes from 1985 to 1994, the whole system of banks experienced Bad Management, Bad Luck, Skimping and Moral Hazard issues, and these problems remain during the second period, i.e., from 1995 to 2005 . The result is the same by bank size.

We can, as a caveat, argue that the hypotheses stated by DeYoung and Berge (1997) can have different interpretations; the conclusions will depend on how NPL, Capital and Efficiency change over time. There can be different interpretations for Bad Luck and Bad Management. Here, we are trying to examine the rise in shares of NPL.

For all the periods in study there is any heterogeneity in the results by banks' size even though the lending practices are typically different. 


\section{Chapter 6}

\section{Summary and Concluding Remarks}

\subsection{Summary}

The three essays address issues on banks' relative efficiency. We use efficiency indicators to analyze different aspects of the banking system. Branch deregulation in the US banking system is one of the main issues discussed in the first four chapters of the present proposal. In the chapter four, different hypotheses that explain the proportion of nonperforming loans held by banks are discussed and re-evaluated including size effects for different time periods.

The first chapter contains the introduction of the dissertation. We explain in detail the idea contained on each chapter. Here, we present the general idea for each one of the essays.

The second chapter presents a review of the situation before and after the enactment of the Riegle Neal Act of 1994, which eliminated banks' restriction to open a branch in other states. The chapter discusses the different points of view regarding branching restrictions and describes the relevant events that resulted in the enactment of the law in 1994.

The third chapter develops a theoretical model where banks spatially compete in loan interest rate under different scenarios. The scenarios vary depending on whether a bank is allowed or not to open a branch in another state. The model integrates some of the salient points of the discussion presented in the preceding chapter about the situation before and after the enactment Riegle Neal Act of 1994. This chapter is the complement of the next chapter that analyzes the state branch deregulation in US.

The fourth chapter presents an empirical analysis of the effects of banking deregulation. I 1994, as mentioned earlier, branching restrictions were eliminated for all states in the US. 
However, many states have relaxed branching restrictions well before that year. The objective of this chapter is to determine whether this deregulation process affected banks' efficiency.

The fifth chapter presents an analysis of the main factors that explain higher shares of nonperforming loans. The analysis follows the seminal paper by Berger and DeYoung (1997). However, the paper extends the analysis in two directions. First, it takes bank size into account. Second, it considers a longer time span.

\subsection{Concluding Remarks}

Branching restriction has been one of the most important issues in the US banking system. There has been a long era of debates before and after the enactment of the McFadden Act of 1927. Some of the consequences of such policy have been observed especially during the 80's. There were many bank failures, mergers and acquisitions.

In a theoretical model we attempt to capture the main argument of those who supported branching restrictions and those who were against. One of the main reasons for branching restriction is bank concentration. The model predicts that when branch diversification is permitted, big banks remove smaller ones from the market. Consumer Welfare and banks' profits may be affected when the government restricts banks to open branches in another state. One of the findings of the model is that when the costs of performing long-distance transactions decline, the restriction to open branches elsewhere is not binding

During the 1970s, some states passed different state laws that eliminate branching restrictions. In an empirical paper, we study the influence of banking and branching state deregulation on banks' efficiency. This process concluded with the enactment of the Riegle Neal Act of 1994. 
Efficiency is calculated using Data Envelopment Analysis technique (DEA). The estimation is based on the seminal paper by Farrel (1957). Farrel (1957), however, did not obtain efficiency for the case of multiple input-outputs. Charnes, Cooper and Rhodes (1978) addressed this issue with linear programming methods.

The period under study is 1984-1997. There are not financial statements before 1984 for many U.S banks. On the other hand, three years after the Riegle Neal Act of 1994 are enough to account for any change in efficiency due to this law.

The estimated efficiency indicator is calculated for each bank and varies over time. We use DEA scores to analyze the effect of each state branch deregulation law on banks' efficiency. In addition, a failure prediction model is run following what most banks' examiners use to predict failure and banks' health: the Capital adequacy, Asset quality, Management quality, Earning ability and Liquidity position ratio (C.A.M.E.L). We consider that DEA scores are a good proxy of management assessment.

Size and regional effects for banks are considered in the paper. We find that banks located in the South were the most inefficient ones. Special Interest from the South may have passed a law that limits bank competition, especially from large banks. All banks, regardless of their location and size improve their efficiency with state deregulation.

Bank failure is also affected by the elimination of bank branching restrictions. Banks in states that eliminated branching restrictions are less exposed to failure and banks in the Midwest are more likely to fail over the period under study.

In the last study, we test four hypotheses elaborated by DeYoung and Berger (1997) to explain why banks hold a high fraction of nonperforming loans (NPLs) as a proportion of total loans. DeYoung and Berger (1997) called theses hypotheses: Bad Luck, Bad Management, Skimping Hypothesis and Moral Hazard. The Bad Luck hypothesis sustains that external factors, outside the managers control, would increase the share of NPLs. The Bad Management 
hypothesis states that management practices would increase such proportion. Under the Skimping hypothesis, the bank may find it optimal to lower costs in the short run by skimping on the resources devoted to underwrite and monitor loans. At the end, the bank will bear the consequences of a high share of non performing loans. Therefore there is a trade-off between short run operating cost and future loan performance. The Moral Hazard hypothesis is the classical problem that DeYoung and Berger (1997) describe as excessive risk-taking when another party is bearing part of the risk and cannot easily charge for or prevent that risk-taking. Low capital results in an increase of the riskiness of the loan portfolio.

We extend the analysis of Berger and DeYoung (1997) by taking into account bank size and different periods of time. We found that besides the heterogeneity of banks lending practices by size there is a homogeneous outcome in terms of the intertemporal relationship between the share of nonperforming loans, efficiency and capital as a ratio of assets. 


\section{Appendix}

Table 4.1: DEA Indicators Summary Results

\begin{tabular}{rrrrrrrr}
\hline Year & Banks & Mean & Min & Max & $\begin{array}{c}\text { First } \\
\text { Quartile. }\end{array}$ & Median & $\begin{array}{c}\text { Third } \\
\text { Quartile. }\end{array}$ \\
\hline 1984 & 14320 & 0.331 & 0.118 & 1.000 & 0.276 & 0.315 & 0.412 \\
1985 & 14220 & 0.394 & 0.040 & 1.000 & 0.353 & 0.407 & 0.461 \\
1986 & 14435 & 0.431 & 0.088 & 1.000 & 0.407 & 0.433 & 0.463 \\
1987 & 13943 & 0.530 & 0.029 & 1.000 & 0.503 & 0.537 & 0.575 \\
1988 & 13382 & 0.555 & 0.094 & 1.000 & 0.532 & 0.570 & 0.605 \\
1989 & 12978 & 0.118 & 0.038 & 1.000 & 0.108 & 0.115 & 0.125 \\
1990 & 12605 & 0.491 & 0.123 & 1.000 & 0.458 & 0.493 & 0.533 \\
1991 & 12198 & 0.398 & 0.132 & 1.000 & 0.375 & 0.399 & 0.429 \\
1992 & 11827 & 0.493 & 0.163 & 1.000 & 0.469 & 0.499 & 0.531 \\
1993 & 11422 & 0.531 & 0.180 & 1.000 & 0.504 & 0.537 & 0.574 \\
1994 & 10946 & 0.437 & 0.024 & 1.000 & 0.406 & 0.442 & 0.482 \\
1995 & 10416 & 0.322 & 0.126 & 1.000 & 0.295 & 0.317 & 0.347 \\
1996 & 9990 & 0.441 & 0.148 & 1.000 & 0.418 & 0.442 & 0.470 \\
1997 & 9567 & 0.347 & 0.041 & 1.000 & 0.328 & 0.348 & 0.371 \\
\hline
\end{tabular}


Table 4.2: Intrastate Branching Deregulation by State

\begin{tabular}{|l|l|l|l|}
\hline STATE & Deregulation & STATE & Deregulation \\
Alabama & 1981 & Montana & 1990 \\
Alaska & 1970 & Nevada & 1970 \\
Arizona & 1970 & New Hampshire & 1987 \\
Arkansas & 1994 & New Jersey & 1977 \\
California & 1970 & New Mexico & 1991 \\
Colorado & 1991 & New York & 1976 \\
Connecticut & 1980 & North Carolina & 1970 \\
Delaware & 1970 & North Dakota & 1987 \\
District of Columbia & 1970 & Ohio & 1979 \\
Florida & 1988 & Oklahoma & 1988 \\
Georgia & 1983 & Oregon & 1985 \\
Idaho & 1970 & Pennsylvania & 1982 \\
Illinois & 1988 & Rhode Island & 1970 \\
Indiana & 1989 & South Carolina & 1970 \\
Iowa & 1994 & South Dakota & 1970 \\
Kansas & 1987 & Tennessee & 1985 \\
Kentucky & 1990 & Texas & 1988 \\
Louisiana & 1988 & Utah & 1981 \\
Maine & 1975 & Vermont & 1970 \\
Maryland & 1970 & Virginia & 1978 \\
Massachusetts & 1984 & Washington & 1985 \\
Michigan & 1987 & West Virginia & 1987 \\
Minnesota & 1993 & 1990 \\
Mississippi & 1986 & Wisconsin & 1988 \\
Missouri & 1990 & Wyoming & \\
\hline
\end{tabular}

Source: Kroszner and Strahan (1999). The year express when full intrastate branching is permitted. Intrastate branching means that a bank can have more than one office within its home state if and only if the other state allows to branch.

There are four branch deregulations. Two of them concern Bank Holding Companies and two for Commercial Banks. The deregulation of Commercial Banks was given through Merger and acquisitions and then full Intrastate was permitted. We have considered the latter deregulation as relevant for our study. 


\section{3: Distribution of states by the assigned four regions}

\begin{tabular}{|c|c|c|c|}
\hline North & South & Midwest & West \\
\hline Connecticut & Delaware & Indiana & Arizona \\
\hline Maine & District of Columbia & Illinois & Colorado \\
\hline Massachusetts & Florida & Michigan & Idaho \\
\hline New Hampshire & Georgia & Ohio & New Mexico \\
\hline Rhode Island & Maryland & Wisconsin & Montana \\
\hline Vermont & North Carolina & Iowa & Utah \\
\hline New Jersey & South Carolina & Kansas & Nevada \\
\hline New York & Virginia & Minnesota & Wyoming \\
\hline \multirow[t]{9}{*}{ Pennsylvania } & West Virginia & Missouri & Alaska \\
\hline & Alabama & Nebraska & California \\
\hline & Kentucky & South Dakota & Oregon \\
\hline & Mississippi & North Dakota & Washington \\
\hline & Tennessee & & \\
\hline & Arkansas & & \\
\hline & Louisiana & & \\
\hline & Oklahoma & & \\
\hline & Texas & & \\
\hline
\end{tabular}

Source: US Census Bureau. 
Table 4.4: Determinants of DEA scores: Pool Estimations ${ }^{72}$

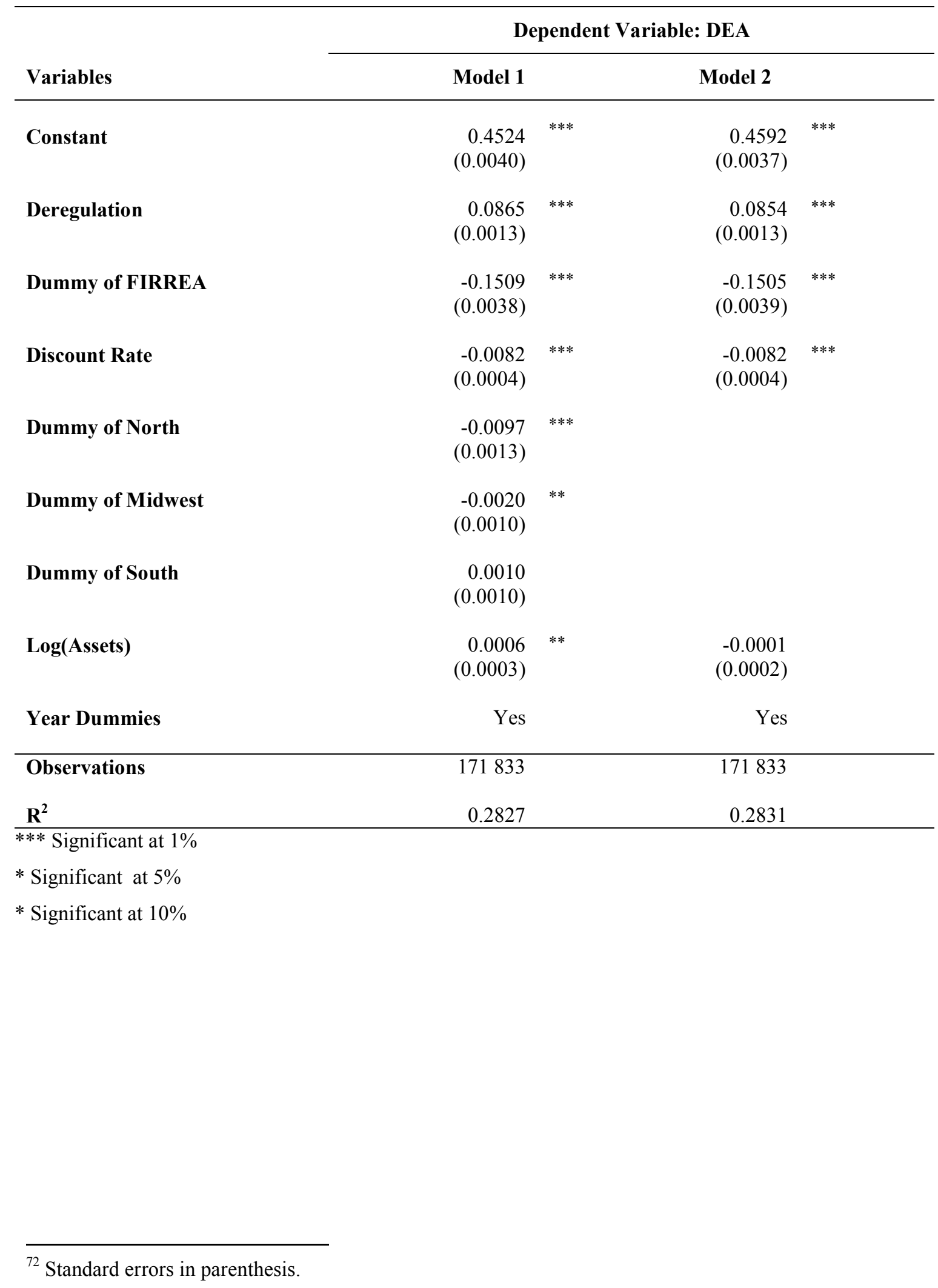


Table 4.5: Determinants of Banks Failure: Three year Logit Model ${ }^{73}$

\begin{tabular}{|c|c|c|c|c|c|c|c|c|}
\hline \multirow{4}{*}{$\begin{array}{l}\text { Variables } \\
\text { Constant }\end{array}$} & \multicolumn{8}{|c|}{ Dependent Variable : Dummy of Failure } \\
\hline & \multicolumn{2}{|c|}{ Model 1} & \multicolumn{2}{|c|}{ Model 2} & \multicolumn{2}{|c|}{ Model 3} & \multicolumn{2}{|c|}{ Model 4} \\
\hline & -23.285 & $* * *$ & -22.415 & $* * *$ & -22.749 & $* * *$ & -22.621 & $* * *$ \\
\hline & $(0.1543)$ & & $(0.1279)$ & & $(0.166)$ & & $(0.1417)$ & \\
\hline \multirow[t]{2}{*}{ DEA } & 0.155 & & & & 0.092 & & & \\
\hline & $(0.2549)$ & & & & $(0.2573)$ & & & \\
\hline \multirow[t]{2}{*}{ Capital/Assets } & -36.289 & $* * *$ & -36.842 & $* * *$ & -33.817 & $* * *$ & -34.419 & $* * *$ \\
\hline & $(0.9902)$ & & $(0.992)$ & & $(0.9721)$ & & $(0.9754)$ & \\
\hline \multirow[t]{2}{*}{ Nonperforming Loans/Assets } & 25.739 & $* * *$ & 24.996 & $* * *$ & 26.579 & $* * *$ & 25.677 & $* * *$ \\
\hline & $(0.8483)$ & & $(0.8512)$ & & $(0.8596)$ & & $(0.8633)$ & \\
\hline \multirow[t]{2}{*}{ Profits/Capital } & -47.192 & $* * *$ & -47.677 & $* * *$ & -44.387 & $* * *$ & -44.786 & $* * *$ \\
\hline & $(1.9010)$ & & $(1.8845)$ & & (1.877) & & (1.8596) & \\
\hline \multirow[t]{2}{*}{ Inverse (Loans/Deposits) } & -1.944 & $* * *$ & -1.953 & $* * *$ & -1.967 & $* * *$ & -1.9084 & $* * *$ \\
\hline & $(0.1218)$ & & $(0.1224)$ & & $(0.1261)$ & & $(0.1262)$ & \\
\hline \multirow[t]{2}{*}{ Deregulation } & & & -0.753 & $* * *$ & & & -0.812 & $* * *$ \\
\hline & & & $(0.0649)$ & & & & $(0.0676)$ & \\
\hline \multirow[t]{2}{*}{ Dummie of North } & & & & & -0.103 & & -0.059 & \\
\hline & & & & & $(0.1060)$ & & $(0.1084)$ & \\
\hline \multirow[t]{2}{*}{ Dummie of Midwest } & & & & & 0.479 & $* * *$ & 0.458 & $* * *$ \\
\hline & & & & & $(0.0679)$ & & $(0.0679)$ & \\
\hline \multirow[t]{2}{*}{ Dummie of South } & & & & & -0.920 & $* * *$ & -0.958 & $* * *$ \\
\hline & & & & & $(0.0804)$ & & $(0.0804)$ & \\
\hline Year Dummies & \multicolumn{2}{|l|}{ Yes } & \multicolumn{2}{|l|}{ Yes } & \multicolumn{2}{|l|}{ Yes } & \multicolumn{2}{|l|}{ Yes } \\
\hline Observations & 119559 & & 119559 & & 119559 & & 119559 & \\
\hline McFadden's LRI & 0.4245 & & 0.4290 & & 0.4475 & & 0.4524 & \\
\hline \multicolumn{9}{|l|}{$* * *$ Significant at $1 \%$} \\
\hline \multicolumn{9}{|l|}{ * Significant at 5\% } \\
\hline \multicolumn{9}{|l|}{$*$ Significant at $10 \%$} \\
\hline
\end{tabular}


Table 4.6: Marginal Effects of the Logit Model.

\begin{tabular}{|c|c|c|c|c|c|c|c|c|}
\hline \multirow{3}{*}{$\begin{array}{l}\text { Variables } \\
\text { Capital/Assets }\end{array}$} & \multicolumn{8}{|c|}{ Dependent Variable : Dummy of Failure } \\
\hline & \multicolumn{2}{|c|}{ Model 1} & \multicolumn{2}{|c|}{ Model 2} & \multicolumn{2}{|c|}{ Model 3} & \multicolumn{2}{|c|}{ Model 4} \\
\hline & 0.017 & $* * *$ & 0.021 & $* * *$ & 0.019 & $* * *$ & 0.014 & $* * *$ \\
\hline Nonperforming Loans/Assets & 0.001 & $* * *$ & 0.002 & $* * *$ & 0.002 & $* * *$ & 0.001 & $* * *$ \\
\hline Profits/Capital & 0.002 & $* * *$ & 0.003 & $* * *$ & 0.003 & $* * *$ & 0.002 & $* * *$ \\
\hline Inverse (Loans/Deposits) & 0.116 & $* * *$ & 0.143 & $* * *$ & 0.127 & $* * *$ & 0.096 & $* * *$ \\
\hline DEA & 0.157 & & & & 0.086 & & & \\
\hline Deregulation & & & 0.098 & $* * *$ & & & 0.129 & $* * *$ \\
\hline Dummie of North & & & & & 0.018 & & 0.014 & \\
\hline Dummie of Midwest & & & & & 0.073 & $* * *$ & 0.057 & $* * *$ \\
\hline Dummie of South & & & & & 0.089 & $* * *$ & 0.067 & $* * *$ \\
\hline
\end{tabular}

*** Significant at $1 \%$

* Significant at 5\%

* Significant at $10 \%$ 
Figure 4.1: A graphical explanation of the DEA

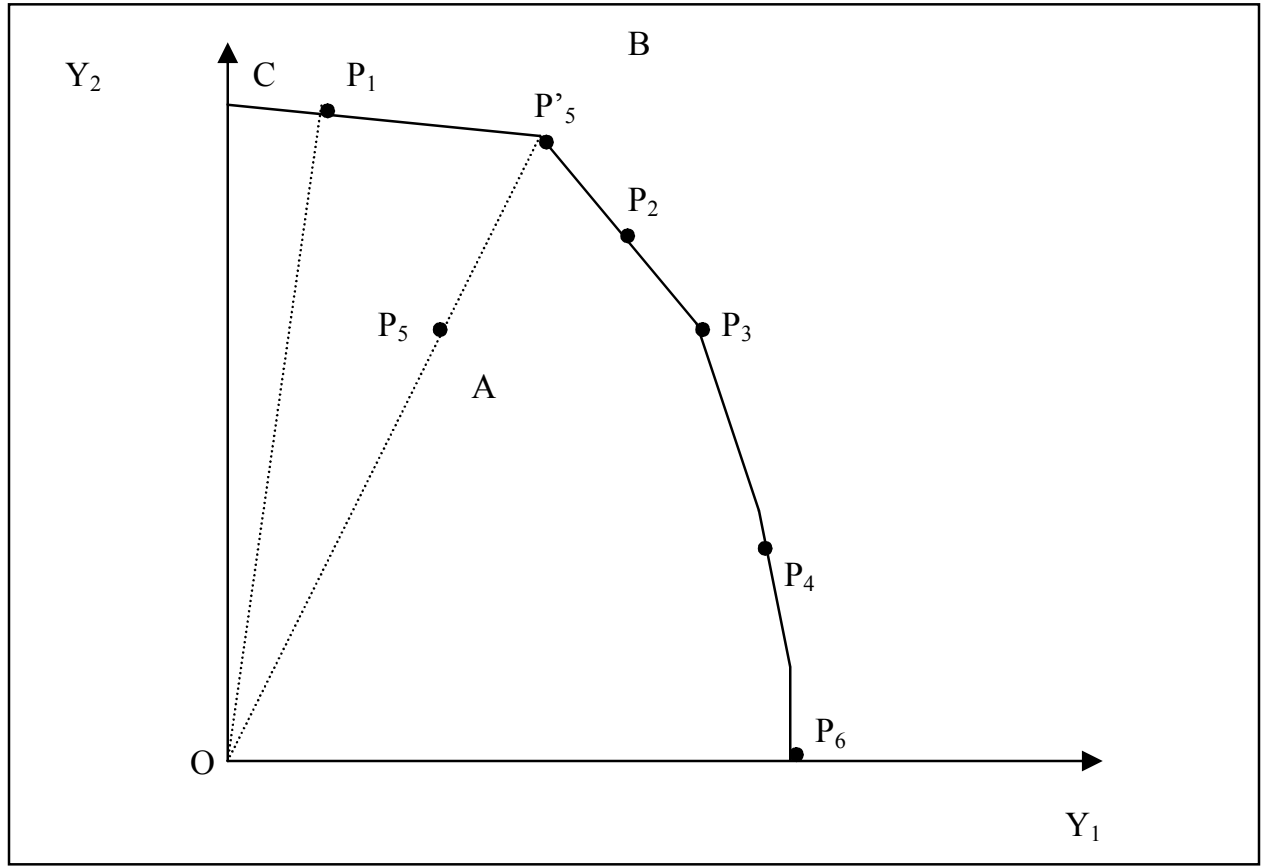

Note: The units P1, P2, P3 and P4 are efficient while, P5 and P6 are inefficient. $\mathrm{Y}_{1}$ and $\mathrm{Y}_{2}$ are outputs.

\section{Figure 4.2: DEA by Quartiles}

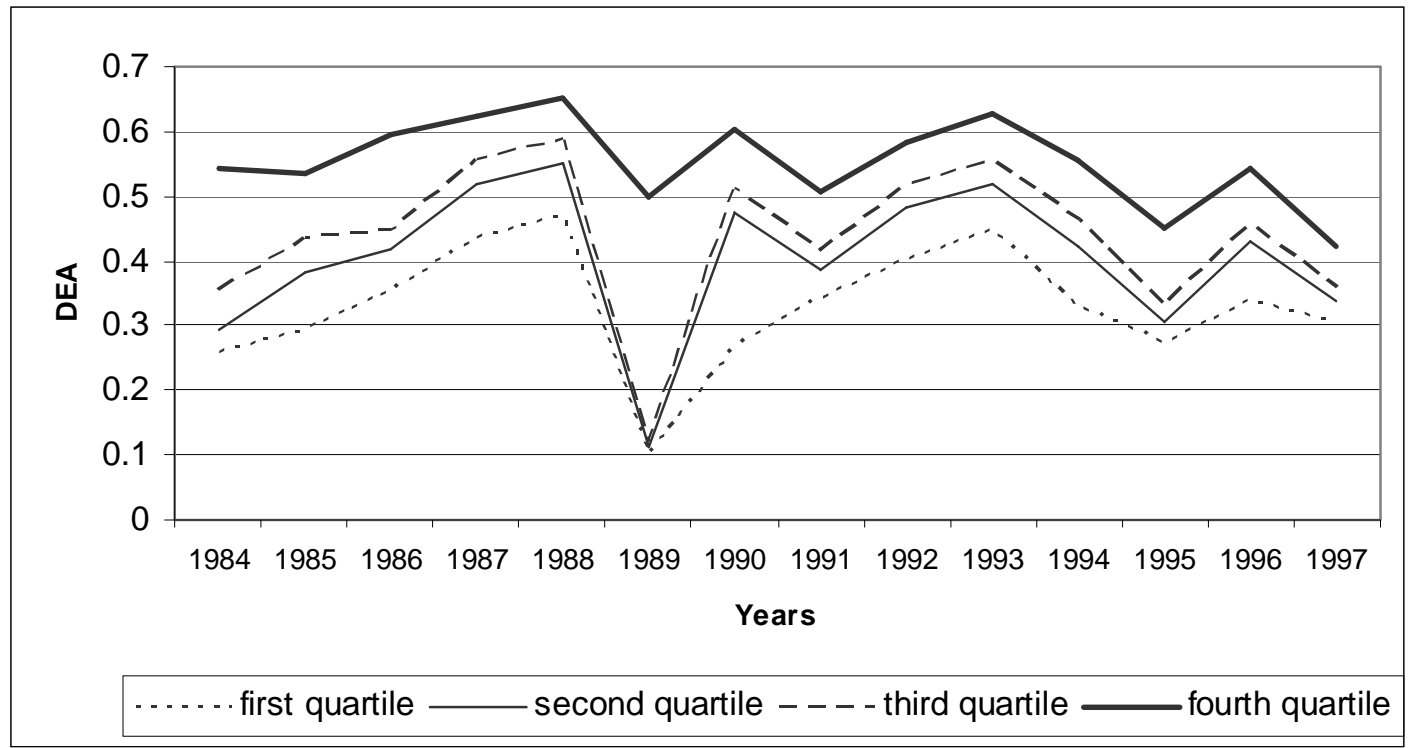

Note: The difference between the average DEA for the first and the last quartile is significant for each year. 
Figure 4.3: Average DEA scores by states (1984)

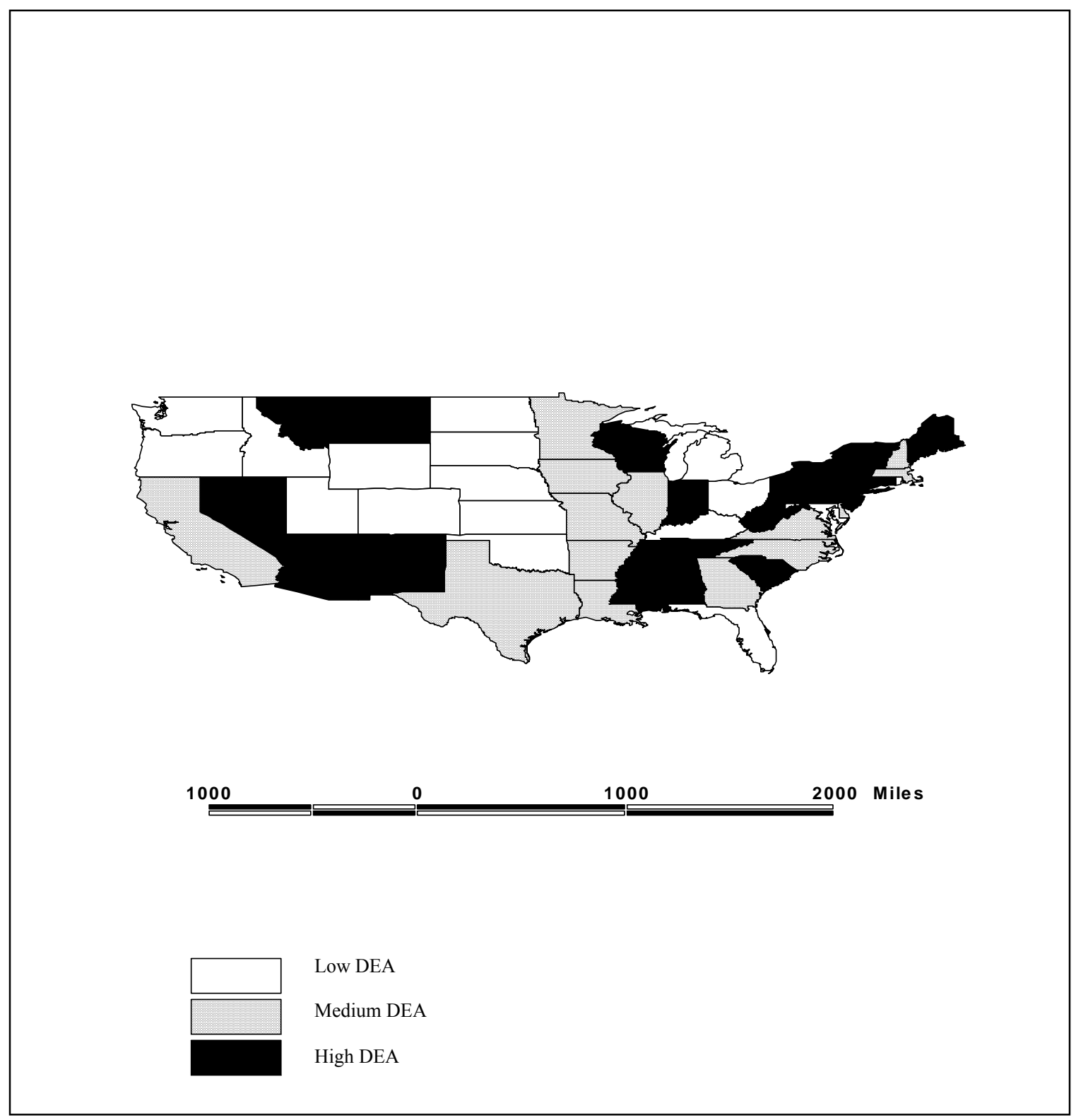

Note: The map has being constructed by averaging bank's DEA in that state. High DEA reflects states with the most efficient score on average. 
Figure 4.4 :Average DEA scores by states (1997)

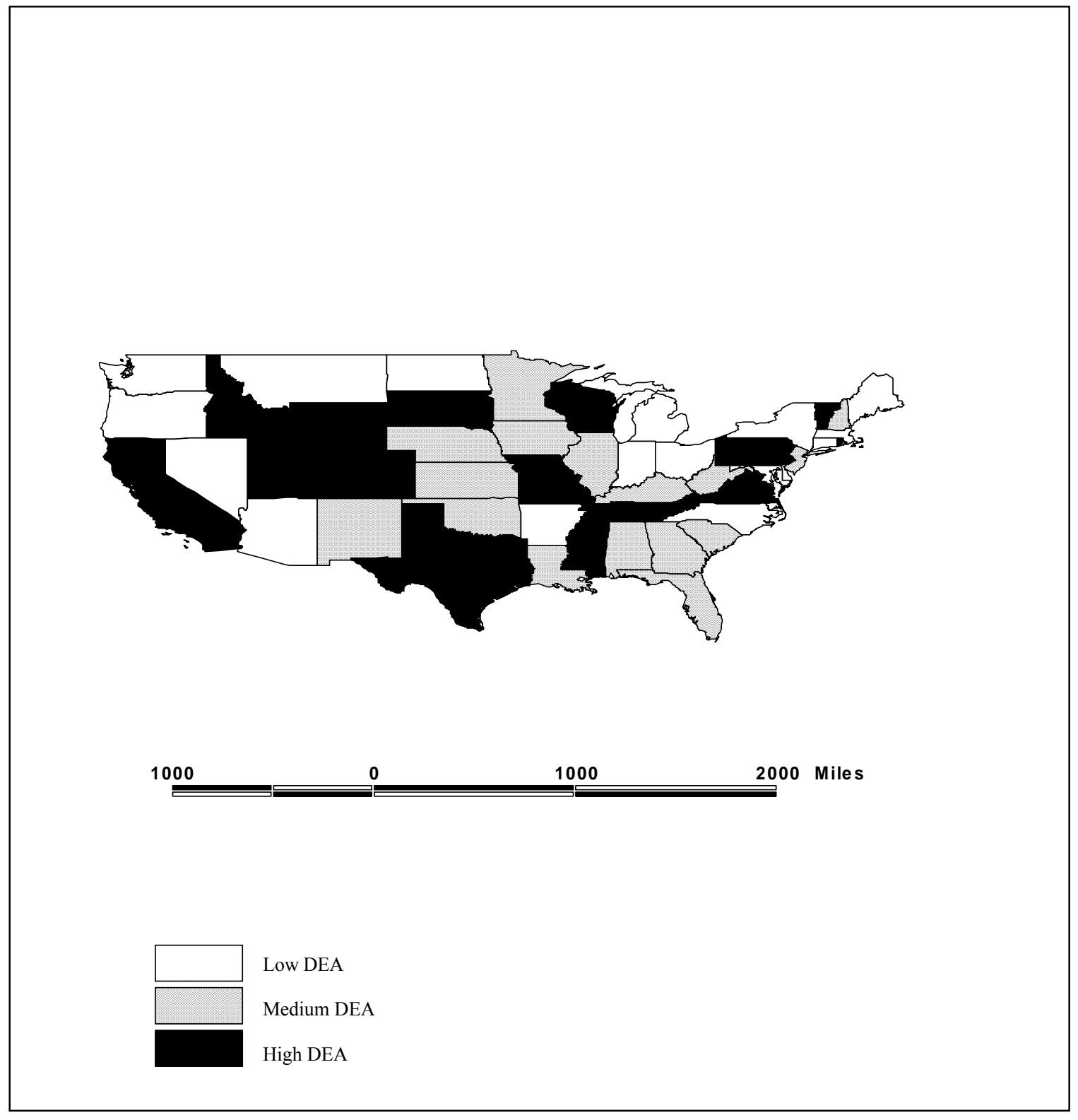

Note: The map has being constructed by averaging bank's DEA in that state. High DEA reflects states with the most efficient score on average. 


\section{Figure 4.5: DEA for Regions}

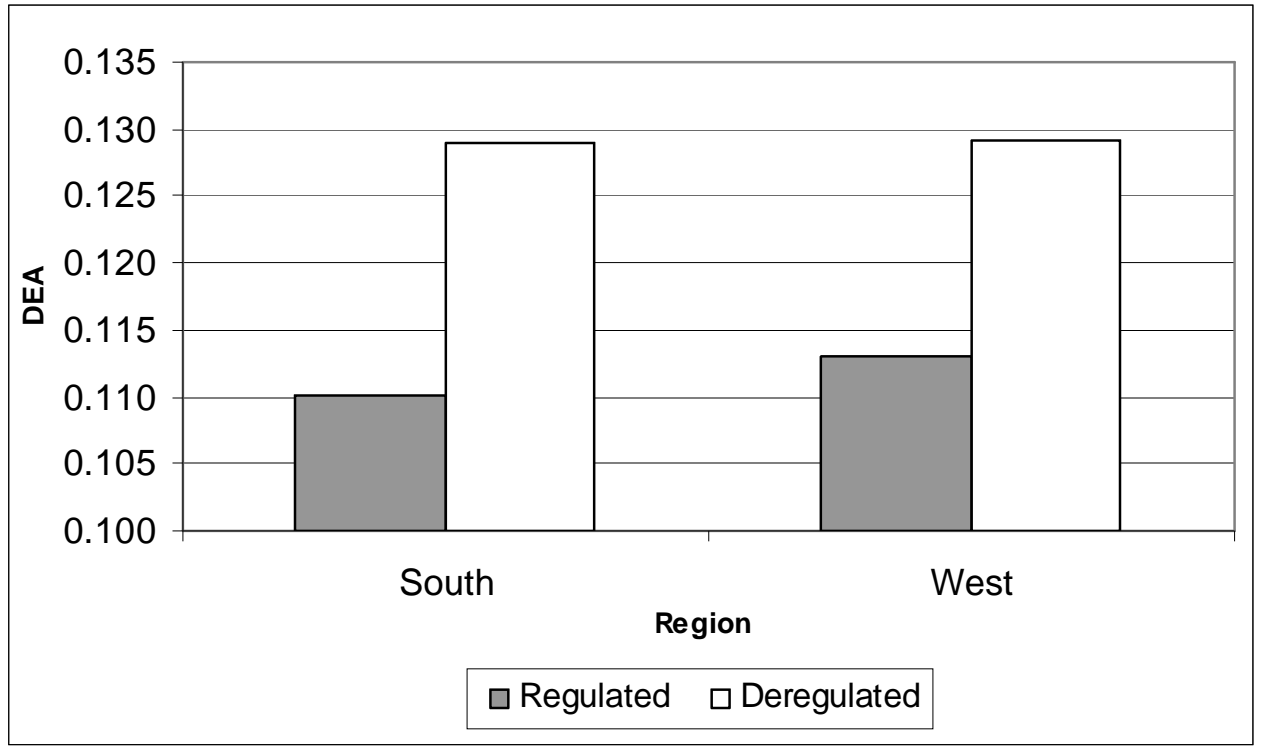

Note: The values correspond to 1989. We dropped the North and Midwest regions because, at that time, all banks in the North and Midwest were deregulated by enacting state laws. The regional division of the states is a standard division. 

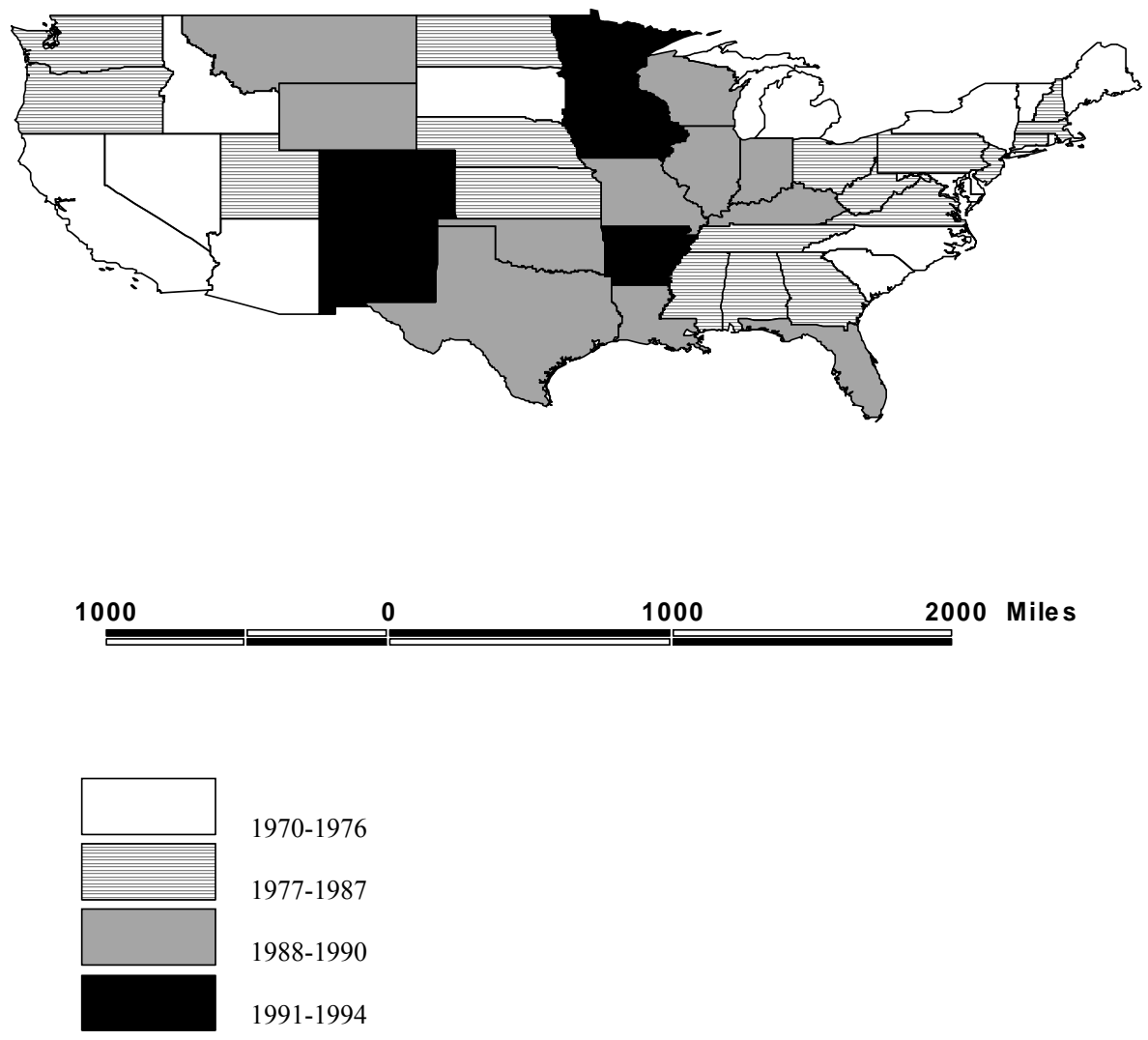

1970-1976

1977-1987

1988-1990

1991-1994

Source: Kroszner and Strahan (1999). The map has been constructed by marking the states that had Intrastate branching deregulation in four intervals of time 
Figure 4.7: Banks by Regions with assets below US100 Mill.

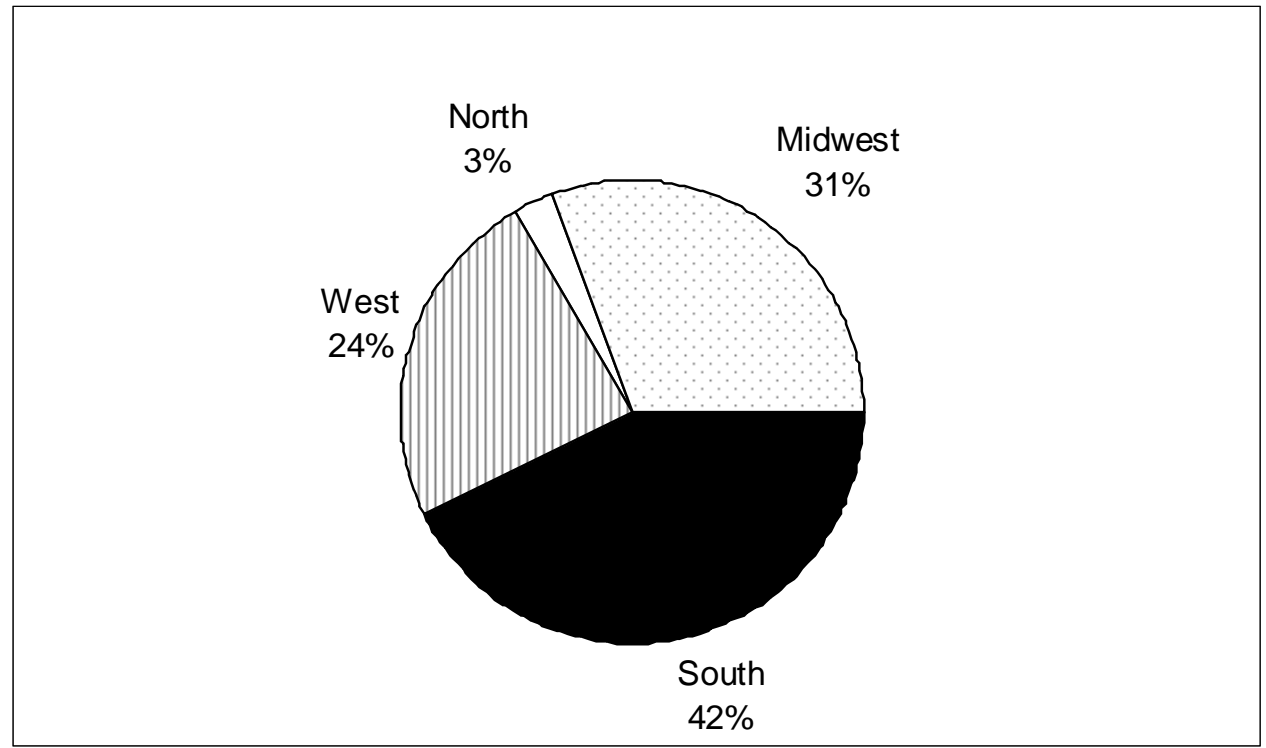

Note: We consider banks that in 1984 hold assets below US\$100 Mill. The amount of assets is expressed in nominal terms.

Figure 4.8: Number of Failing Banks by Region

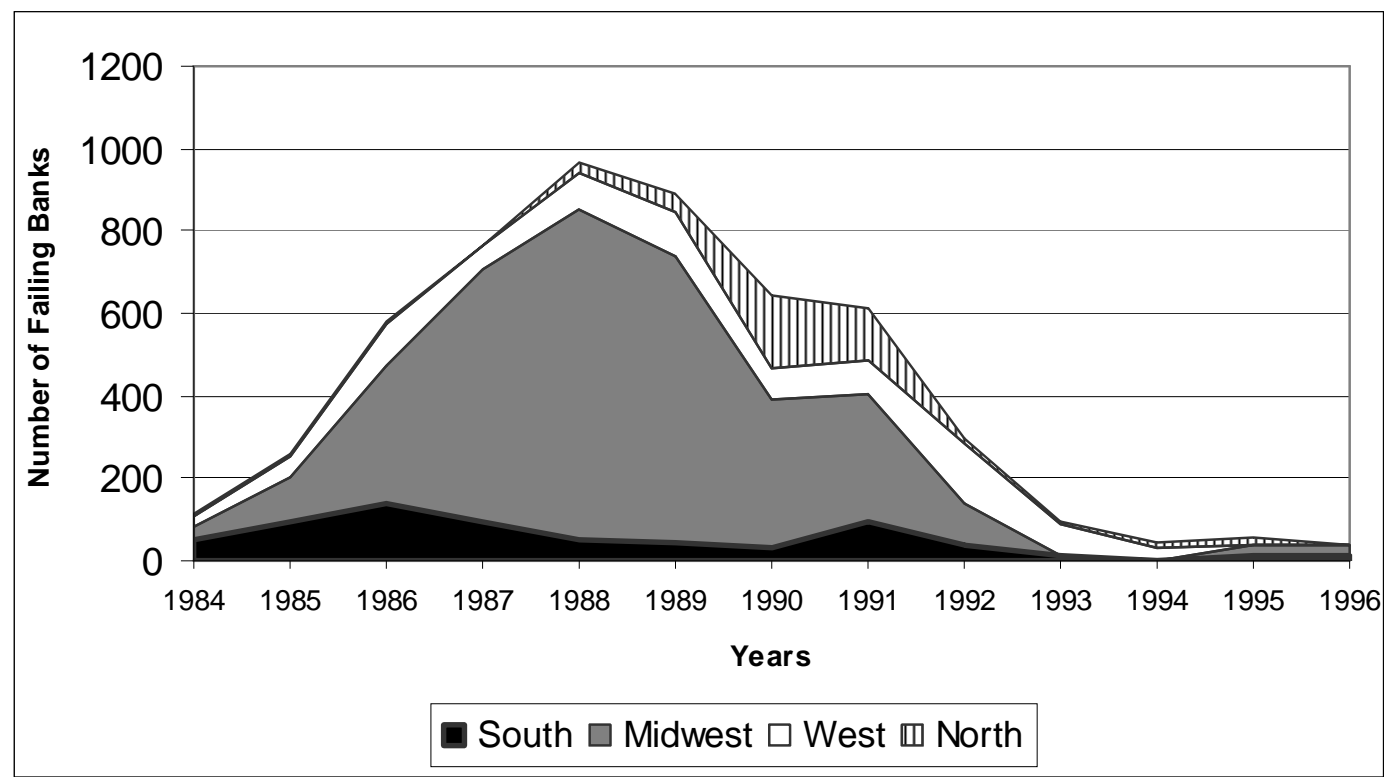

Note: The failing institutions are not merged or acquired. 
Figure 4.9: Number of Failing Banks by Size

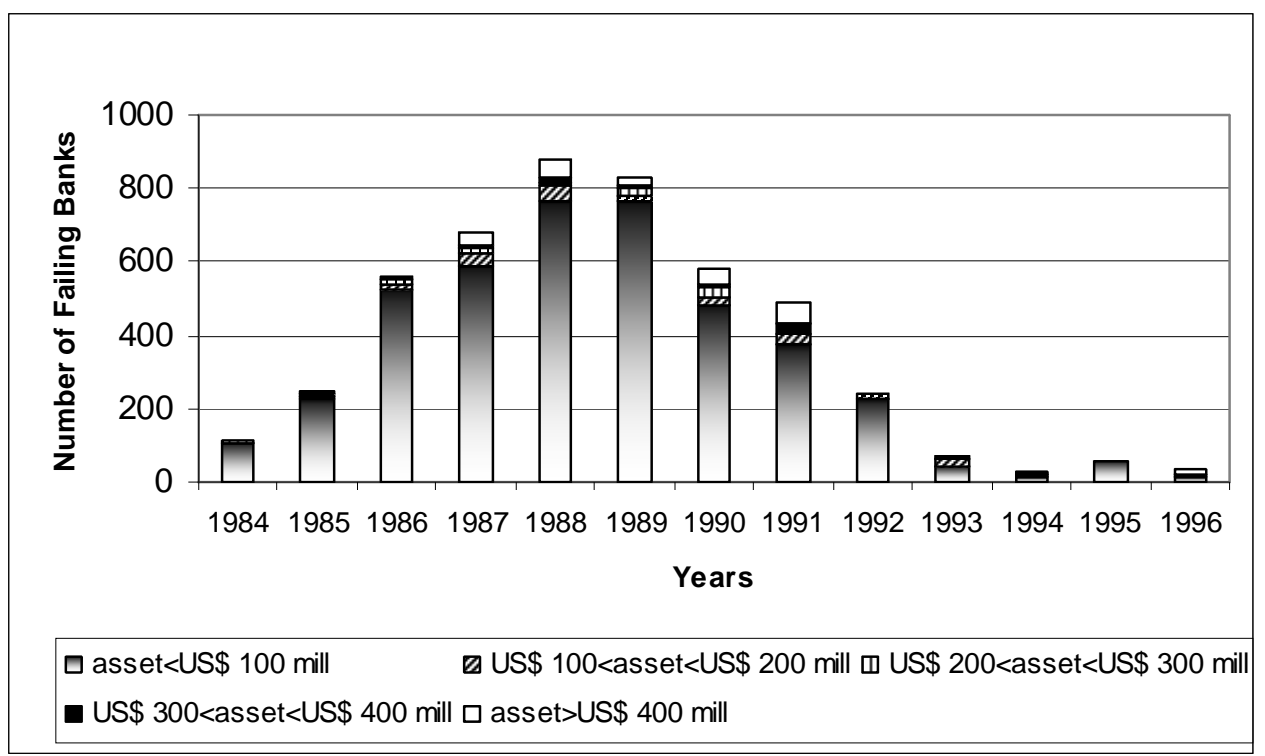

Note: The failing institutions are not merged or acquired. The size intervals are constructed in real dollars (1996=100) 
Table 4.7: Definitions and descriptive statistics for the variables employed in the Pool and Logit Model (for the whole period 1984-1997).

\begin{tabular}{|c|c|c|c|}
\hline Variables & Explanation & Mean & Std. dev \\
\hline DEA & $\begin{array}{l}\text { Efficiency calculated with } \\
\text { Data Envelopment Analysis }\end{array}$ & 0.42 & 0.14 \\
\hline Discount Rate & Macroeconomic variable & 5.12 & 2.29 \\
\hline Log(Asset) & Logarithm of Assets & 10.74 & 1.12 \\
\hline Capital/Assets & Capital Adequacy & 0.09 & 0.04 \\
\hline $\begin{array}{l}\text { Nonperforming } \\
\text { Loans/Assets }\end{array}$ & Asset Performance & 0.54 & 0.15 \\
\hline Profits/Capital & ROE & 0.02 & 0.01 \\
\hline Loans/Deposits & Proxy for Liquidity & 23.33 & 13.55 \\
\hline Dummy of North & Regional Dummie & \multicolumn{2}{|c|}{$\%$ of Observations } \\
\hline Dummy of Midwest & Regional Dummie & \multicolumn{2}{|c|}{$36 \%$} \\
\hline Dummy of South & Regional Dummie & \multicolumn{2}{|c|}{$42 \%$} \\
\hline Dummy of FIRREA & $\begin{array}{l}\text { Dummier } 1989=1 ;=0 \\
\text { otherwise }\end{array}$ & \multicolumn{2}{|c|}{$43 \%$} \\
\hline Deregulation & $\begin{array}{l}\text { Dummie for State Branch } \\
\text { Deregulation }\end{array}$ & \multicolumn{2}{|c|}{$82 \%$} \\
\hline
\end{tabular}


Figure 5.1: Evolutions of Shares of NPL, Capital and Efficiency ${ }^{74}$
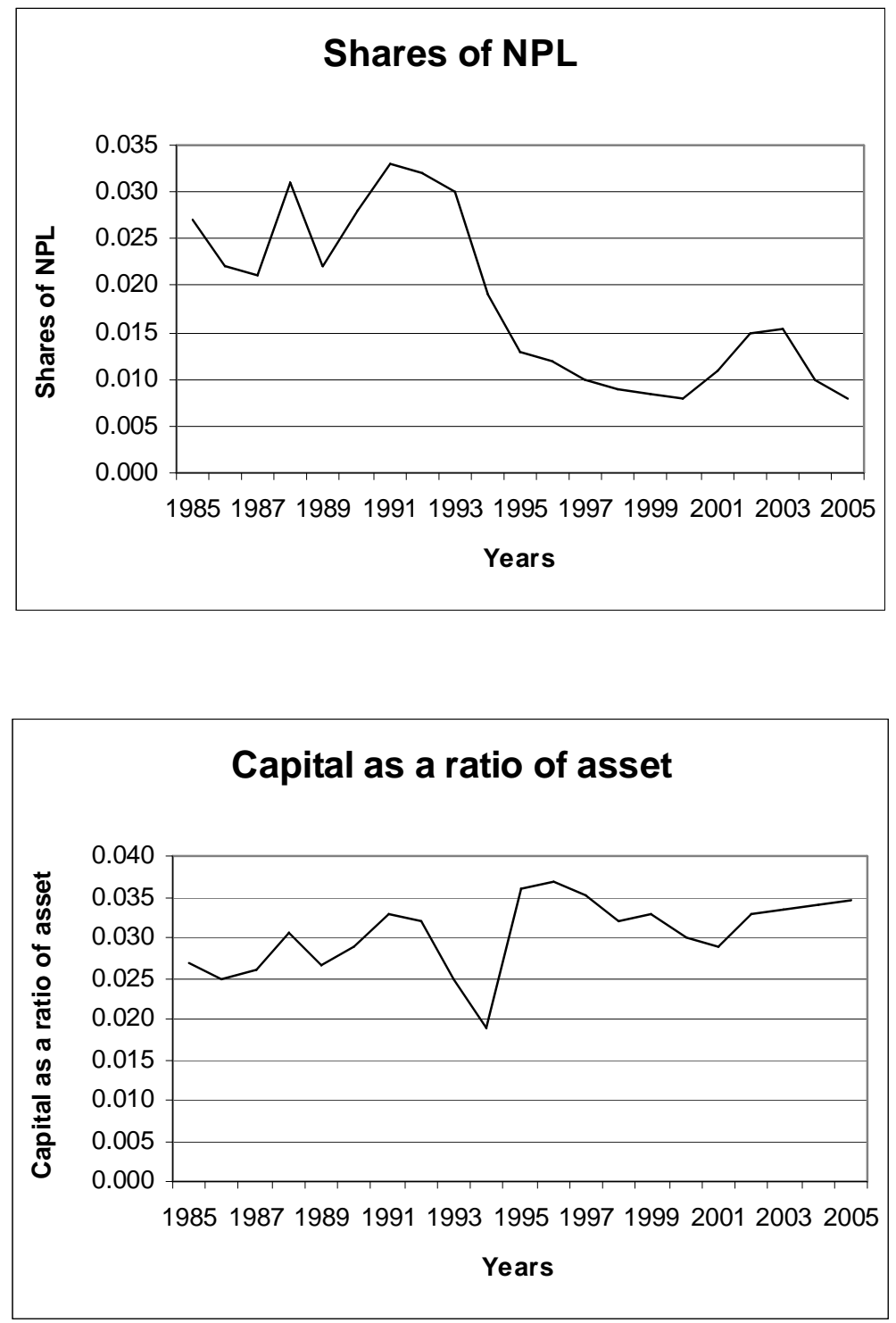

\footnotetext{
${ }^{74}$ They have been constructed by taking an average of the shares of NPL, shares of Capital and Efficiency over time. The graph has been constructed by using as input the data from Federal Reserve of Chicago.
} 


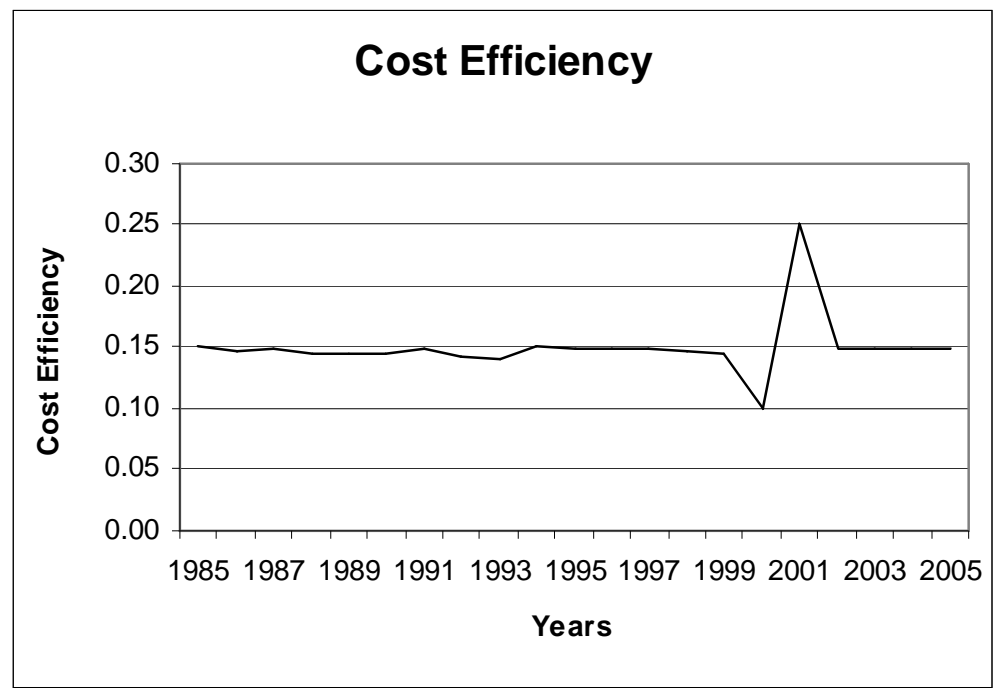

Figure 5.2: Size Distribution of Banks in 1990 and 2000

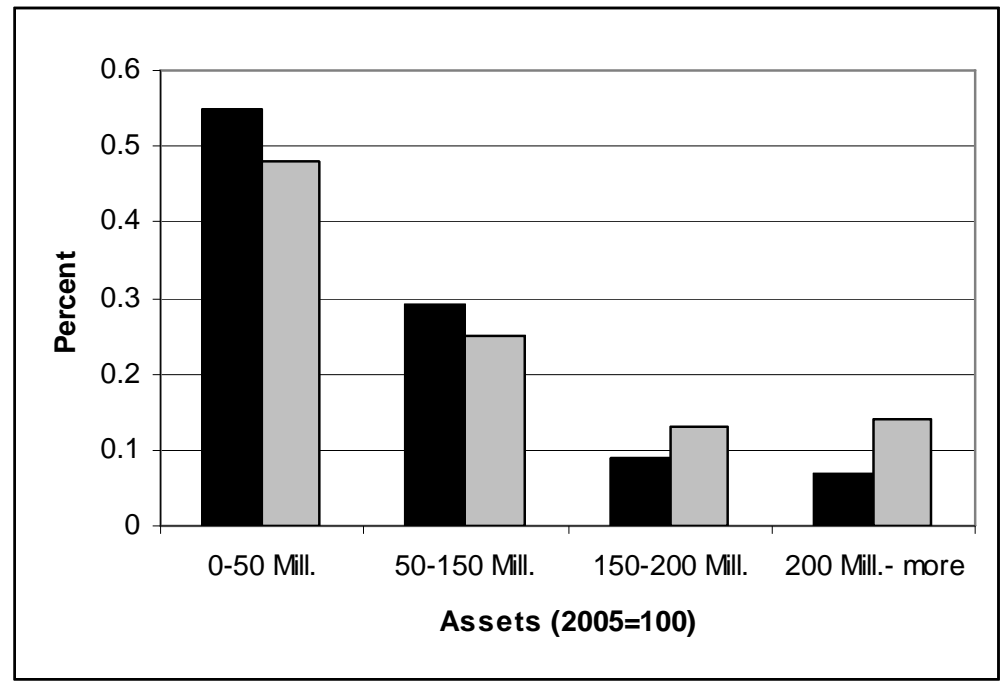

Note : The data comes the Federal Reserve of Chicago. 
Table 5.1: Cost Efficiency Scores.

\begin{tabular}{ccccc}
\hline Year & Banks & Mean & Min & Max \\
\hline 1985 & 14,220 & 0.1513 & 0.0813 & 0.4470 \\
1986 & 14,435 & 0.1473 & 0.0797 & 0.3207 \\
1987 & 13,943 & 0.1506 & 0.0793 & 0.2926 \\
1988 & 13,382 & 0.1473 & 0.0775 & 0.2804 \\
1989 & 12,978 & 0.1447 & 0.0771 & 0.3002 \\
1990 & 12,605 & 0.1447 & 0.0774 & 0.3553 \\
1991 & 12,198 & 0.1503 & 0.0773 & 0.3781 \\
1992 & 11,827 & 0.1425 & 0.0768 & 0.4642 \\
1993 & 11,422 & 0.1412 & 0.0793 & 0.2609 \\
1994 & 10,946 & 0.1517 & 0.0786 & 0.2970 \\
1995 & 10,416 & 0.1398 & 0.0772 & 0.2586 \\
1996 & 9,990 & 0.1384 & 0.0768 & 0.2462 \\
1997 & 9,567 & 0.1416 & 0.0000 & 0.2626 \\
1998 & 9,468 & 0.1413 & 0.0758 & 0.2652 \\
1999 & 9,342 & 0.1292 & 0.0724 & 0.2474 \\
2000 & 9,204 & 0.0992 & 0.0607 & 0.1651 \\
2001 & 9,161 & 0.2685 & 0.0960 & 1.0000 \\
2002 & 8,998 & 0.1440 & 0.0640 & 0.2976 \\
2003 & 8,751 & 0.1329 & 0.0614 & 0.3919 \\
2004 & 8,609 & 0.1363 & 0.0622 & 0.2674 \\
2005 & 8,431 & 0.1345 & 0.0606 & 0.2828 \\
\hline
\end{tabular}


Table 5.2: Granger Causality: NPL/LOAN does not cause Efficiency ${ }^{75}$

\section{Period 1985-2005}

\begin{tabular}{|c|c|c|c|c|c|c|}
\hline \multirow[b]{2}{*}{ Variable } & \multicolumn{6}{|c|}{ Dependent Variable: Efficiency } \\
\hline & \multicolumn{2}{|l|}{ Panel } & \multicolumn{2}{|l|}{ Size 1} & \multicolumn{2}{|l|}{ Size 2} \\
\hline \multirow[t]{2}{*}{ CONSTANT } & 0.1369 & $* * *$ & 0.1637 & $* * *$ & 0.1199 & $* * *$ \\
\hline & $(0.0005)$ & & $(0.0004)$ & & $(0.0003)$ & \\
\hline \multirow[t]{2}{*}{ NPL(-1) } & 0.0081 & $* * *$ & 0.0045 & $* * *$ & -0.0035 & $* * *$ \\
\hline & $(0.0062)$ & & $(0.0012)$ & & $(0.0003)$ & \\
\hline \multirow[t]{2}{*}{ NPL(-2) } & -0.0160 & $* * *$ & -0.0097 & & 0.0020 & \\
\hline & $(0.0059)$ & & $(0.0063)$ & & $(0.0084)$ & \\
\hline \multirow[t]{2}{*}{ NPL(-3) } & -0.0115 & $* * *$ & 0.0019 & & 0.0214 & \\
\hline & $(0.0057)$ & & $(0.0061)$ & & $(0.0080)$ & \\
\hline \multirow[t]{2}{*}{ NPL(-4) } & 0.0001 & & -0.0380 & $* * *$ & -0.0438 & $* * *$ \\
\hline & $(0.0055)$ & & $(0.0052)$ & & $(0.0064)$ & \\
\hline \multirow[t]{2}{*}{ Sum of Coefficients } & -0.0193 & & -0.0413 & & -0.0239 & \\
\hline & $(0.0117)$ & & $(0.0103)$ & & $(0.0132)$ & \\
\hline \multirow[t]{2}{*}{ Efficiency(-1) } & 0.5354 & $* * *$ & 0.4339 & $* * *$ & 0.3702 & $* * *$ \\
\hline & $(0.0169)$ & & $(0.0509)$ & & $(0.0459)$ & \\
\hline \multirow[t]{2}{*}{ Efficiency(-2) } & 0.0004 & & 0.0256 & $* * *$ & 0.0250 & $* * *$ \\
\hline & $(0.0014)$ & & $(0.0030)$ & & $(0.0032)$ & \\
\hline \multirow[t]{2}{*}{ Efficiency(-3) } & 0.0215 & $* * *$ & -0.0002 & $* * *$ & 0.0127 & $* * *$ \\
\hline & $(0.0038)$ & & $(0.0000)$ & & $(0.0017)$ & \\
\hline \multirow[t]{2}{*}{ Efficiency(-4) } & 0.0291 & $* * *$ & 0.0102 & & -0.0192 & $* * *$ \\
\hline & $(0.0085)$ & & $(0.0063)$ & & $(0.0028)$ & \\
\hline \multirow[t]{2}{*}{ Sum of Coefficients } & 0.5864 & & 0.4695 & & 0.3887 & \\
\hline & $(0.0194)$ & & $(0.0514)$ & & $(0.0461)$ & \\
\hline $\mathrm{F}$ & 12.1786 & & 85.2995 & & 4.5301 & \\
\hline $\begin{array}{l}\text { Null Hypothesis: NPL does } \\
\text { not cause Efficiency }\end{array}$ & $\overline{\text { REJECT }}$ & & REJECT & & REJECT & \\
\hline P Value & $<1 \%$ & & $<1 \%$ & & $<1 \%$ & \\
\hline Observations & 127,407 & & 25,536 & & 53,424 & \\
\hline
\end{tabular}

*** Significant at $1 \%$

* Significant at 5\%

* Significant at $10 \%$

${ }^{75} \mathrm{We}$ Control here for Year Dummies as we explained in section 5.6. Standard errors in parenthesis. 
Period 1985-1994

\begin{tabular}{|c|c|c|c|c|c|c|}
\hline \multirow{2}{*}{ Variable } & \multicolumn{6}{|c|}{ Dependent Variable: Efficiency } \\
\hline & \multicolumn{2}{|l|}{ Panel } & \multicolumn{2}{|l|}{ Size1 } & \multicolumn{2}{|l|}{ Size 2} \\
\hline \multirow[t]{2}{*}{ CONSTANT } & 0.1403 & $* * *$ & 0.1612 & $* * *$ & 0.1281 & *** \\
\hline & $(0.0003)$ & & $(0.0002)$ & & $(0.0002)$ & \\
\hline \multirow[t]{2}{*}{ NPL(-1) } & -0.0006 & $* * *$ & -0.0088 & $* * *$ & -0.0475 & $* * *$ \\
\hline & $(0.0001)$ & & $(0.0042)$ & & $(0.0059)$ & \\
\hline \multirow[t]{2}{*}{ NPL(-2) } & -0.0075 & $* * *$ & -0.0138 & $* * *$ & 0.0179 & $* * *$ \\
\hline & $(0.0036)$ & & $(0.0042)$ & & $(0.0069)$ & \\
\hline \multirow[t]{2}{*}{ NPL(-3) } & 0.0003 & & 0.0008 & $* * *$ & -0.033 & $* * *$ \\
\hline & $(0.0034)$ & & $(0.0001)$ & & $(0.0066)$ & \\
\hline \multirow[t]{2}{*}{ NPL(-4) } & -0.0091 & $* * *$ & 0.0017 & $* * *$ & -0.0753 & $* * *$ \\
\hline & $(0.0033)$ & & $(0.0041)$ & & $(0.0052)$ & \\
\hline \multirow[t]{2}{*}{ Sum of Coefficients } & -0.0169 & & -0.0201 & & -0.1379 & \\
\hline & $(0.0060)$ & & $(0.0072)$ & & $(0.0124)$ & \\
\hline \multirow[t]{2}{*}{ Efficiency(-1) } & 0.6960 & $* * *$ & 0.4911 & $* * *$ & 0.4836 & $* * *$ \\
\hline & $(0.0979)$ & & $(0.0383)$ & & $(0.0308)$ & \\
\hline \multirow[t]{2}{*}{ Efficiency(-2) } & 0.0208 & $* * *$ & 0.0023 & & 0.0136 & \\
\hline & $(0.0074)$ & & $(0.0015)$ & & $(0.0014)$ & \\
\hline \multirow[t]{2}{*}{ Efficiency(-3) } & 0.0090 & $* * *$ & 0.0205 & $* * *$ & 0.0015 & \\
\hline & $(0.0020)$ & & $(0.0041)$ & & $(0.0003)$ & \\
\hline \multirow[t]{2}{*}{ Efficiency(-4) } & -0.0247 & $* * *$ & 0.0245 & $* * *$ & 0.0086 & \\
\hline & $(0.0096)$ & & $(0.0110)$ & & $(0.0044)$ & \\
\hline \multirow[t]{2}{*}{ Sum of Coefficients } & 0.7011 & & 0.5385 & & 0.5073 & \\
\hline & $(0.0987)$ & & $(0.0401)$ & & $(0.0311)$ & \\
\hline $\mathrm{F}$ & 197.4864 & & 120.6014 & & 219.1218 & \\
\hline $\begin{array}{l}\text { Null Hypothesis: NPL does } \\
\text { not cause Efficiency }\end{array}$ & REJECT & & REJECT & & REJECT & \\
\hline P Value & $<1 \%$ & & $<1 \%$ & & $<1 \%$ & \\
\hline Observations & 107,620 & & 31,200 & & 51,000 & \\
\hline
\end{tabular}

*** Significant at $1 \%$

* Significant at $5 \%$

* Significant at 10\% 
Period 1995-2005

\begin{tabular}{|c|c|c|c|c|c|c|}
\hline \multirow[b]{2}{*}{ Variable } & \multicolumn{6}{|c|}{ Dependent Variable: Efficiency } \\
\hline & \multicolumn{2}{|l|}{ Panel } & \multicolumn{2}{|l|}{ Size1 } & \multicolumn{2}{|l|}{ Size 2} \\
\hline \multirow[t]{2}{*}{ CONSTANT } & 0.135 & $* * *$ & 0.3289 & $* * *$ & 0.119 & $* * *$ \\
\hline & $(0.0004)$ & & $(0.0007)$ & & $(0.0004)$ & \\
\hline \multirow[t]{2}{*}{ NPL(-1) } & -0.0154 & $* * *$ & 0.0105 & $* * *$ & -0.0685 & $* * *$ \\
\hline & $(0.0004)$ & & $(0.0072)$ & & $(0.0134)$ & \\
\hline \multirow[t]{2}{*}{ NPL(-2) } & -0.0211 & $* * *$ & -0.011 & & -0.0412 & $* * *$ \\
\hline & $(0.0089)$ & & $(0.0173)$ & & $(0.0180)$ & \\
\hline \multirow[t]{2}{*}{ NPL(-3) } & 0.0003 & & -0.0338 & & -0.0225 & \\
\hline & $(0.0096)$ & & $(0.0171)$ & & $(0.0182)$ & \\
\hline \multirow[t]{2}{*}{ NPL(-4) } & -0.0028 & & -0.0233 & & -0.0036 & \\
\hline & $(0.0186)$ & & $(0.0171)$ & & $(0.0153)$ & \\
\hline \multirow[t]{2}{*}{ Sum of Coefficients } & -0.0390 & & -0.0576 & & -0.1358 & \\
\hline & $(0.0227)$ & & $(0.0306)$ & & $(0.0327)$ & \\
\hline \multirow[t]{2}{*}{ Efficiency(-1) } & 0.7540 & $* * *$ & 0.3900 & $* * *$ & 0.4205 & \\
\hline & $(0.3753)$ & & $(0.1544)$ & & $(0.0448)$ & \\
\hline \multirow[t]{2}{*}{ Efficiency(-2) } & 0.0224 & $* * *$ & 0.0240 & $* * *$ & 0.0249 & \\
\hline & $(0.0067)$ & & $(0.0037)$ & & $(0.0097)$ & \\
\hline \multirow[t]{2}{*}{ Efficiency(-3) } & -0.0040 & $* * *$ & 0.0135 & $* * *$ & 0.0121 & \\
\hline & $(0.0007)$ & & $(0.0021)$ & & $(0.0013)$ & \\
\hline \multirow[t]{2}{*}{ Efficiency(-4) } & 0.0005 & $* * *$ & 0.0299 & & 0.0029 & \\
\hline & $(0.0001)$ & & $(0.0832)$ & & $(0.0016)$ & \\
\hline \multirow[t]{2}{*}{ Sum of Coefficients } & 0.7729 & & 0.4574 & & 0.4604 & \\
\hline & $(0.3754)$ & & $(0.1754)$ & & $(0.0459)$ & \\
\hline $\bar{F}$ & 9.893 & & 13.21 & & 7.896 & \\
\hline $\begin{array}{l}\text { Null Hypothesis: NPL does } \\
\text { not cause Efficiency }\end{array}$ & REJECT & & REJECT & & REJECT & \\
\hline P Value & $<1 \%$ & & $<1 \%$ & & $<1 \%$ & \\
\hline Observations & 74,305 & & 16,181 & & 36,223 & \\
\hline
\end{tabular}

*** Significant at $1 \%$

* Significant at 5\%

* Significant at $10 \%$ 
Table 5.3: Granger Causality: Scores of Efficiency that does not cause NPL/LOAN ${ }^{76}$

Period 1985-2005

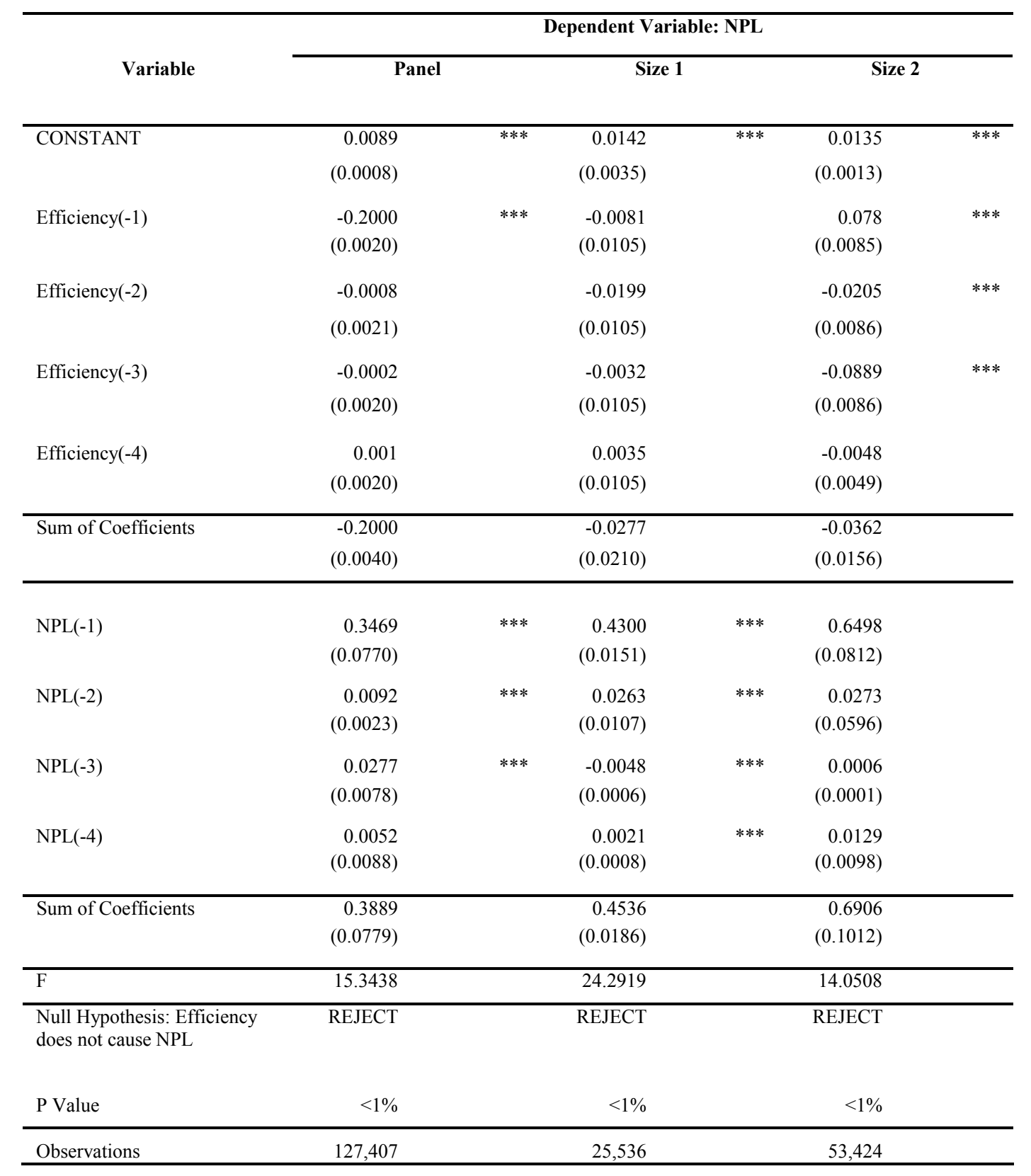

*** Significant at $1 \%$

* Significant at $5 \%$

* Significant at $10 \%$

${ }^{76} \mathrm{We}$ Control here for Year Dummies as we explained in section 5.6. Standard errors in parenthesis. 
Period 1985-1994

\begin{tabular}{|c|c|c|c|c|c|c|}
\hline \multirow[b]{2}{*}{ Variable } & \multicolumn{6}{|c|}{ Dependent Variable: NPL } \\
\hline & \multicolumn{2}{|l|}{ Panel } & \multicolumn{2}{|l|}{ Size1 } & \multicolumn{2}{|l|}{ Size 2} \\
\hline \multirow[t]{2}{*}{ CONSTANT } & 0.006 & $* * *$ & 0.0016 & & 0.0454 & $* * *$ \\
\hline & $(0.0017)$ & & $(0.0043)$ & & $(0.0012)$ & \\
\hline \multirow[t]{2}{*}{ Efficiency(-1) } & -0.0008 & & 0.0025 & & -0.8237 & $* * *$ \\
\hline & $(0.0055)$ & & $(0.0141)$ & & $(0.0366)$ & \\
\hline \multirow[t]{2}{*}{ Efficiency(-2) } & 0.0094 & & -0.0668 & $* * *$ & -0.1763 & $* * *$ \\
\hline & $(0.0056)$ & & $(0.0137)$ & & $(0.0495)$ & \\
\hline \multirow[t]{2}{*}{ Efficiency(-3) } & -0.0276 & $* * *$ & -0.0076 & & -0.3635 & $* * *$ \\
\hline & $(0.0056)$ & & $(0.0140)$ & & $(0.0509)$ & \\
\hline \multirow[t]{2}{*}{ Efficiency(-4) } & 0.0006 & & -0.0695 & $* * *$ & -0.4645 & $* * *$ \\
\hline & $(0.0056)$ & & $(0.0139)$ & & $(0.0388)$ & \\
\hline \multirow[t]{2}{*}{ Sum of Coefficients } & $\begin{array}{c}-0.0184 \\
\end{array}$ & & -0.1414 & & -1.8280 & \\
\hline & $(0.0111)$ & & $(0.0278)$ & & $(0.0888)$ & \\
\hline \multirow[t]{2}{*}{ NPL(-1) } & 0.5091 & $* * *$ & 0.4807 & & 0.6917 & \\
\hline & $(0.1271)$ & & $(0.5482)$ & & $(0.2128)$ & \\
\hline \multirow[t]{2}{*}{ NPL(-2) } & 0.0277 & $* * *$ & 0.0041 & $* * *$ & -0.0130 & \\
\hline & $(0.0030)$ & & $(0.0016)$ & & $(0.0037)$ & \\
\hline \multirow[t]{2}{*}{ NPL(-3) } & 0.0236 & $* * *$ & 0.0255 & $* * *$ & 0.0238 & \\
\hline & $(0.0031)$ & & $(0.0034)$ & & $(0.0052)$ & \\
\hline \multirow[t]{2}{*}{ NPL(-4) } & 0.0187 & $* * *$ & 0.0038 & & 0.0028 & \\
\hline & $(0.0082)$ & & $(0.0037)$ & & $(0.0005)$ & \\
\hline \multirow[t]{2}{*}{ Sum of Coefficients } & 0.5791 & & 0.5142 & & 0.7053 & \\
\hline & $(0.1275)$ & & $(0.5483)$ & & $(0.2129)$ & \\
\hline $\mathrm{F}$ & 4.8173 & & 5.5114 & & 14.9172 & \\
\hline $\begin{array}{l}\text { Null Hypothesis: Efficiency } \\
\text { does not cause NPL }\end{array}$ & REJECT & & REJECT & & REJECT & \\
\hline P Value & $<1 \%$ & & $<1 \%$ & & $<1 \%$ & \\
\hline Observations & 107,620 & & 31,200 & & 51,000 & \\
\hline
\end{tabular}

*** Significant at $1 \%$

* Significant at 5\%

* Significant at 10\% 
Period 1995-2005

\begin{tabular}{|c|c|c|c|c|c|c|}
\hline \multirow[b]{2}{*}{ Variable } & \multicolumn{6}{|c|}{ Dependent Variable: NPL } \\
\hline & \multicolumn{2}{|l|}{ Panel } & \multicolumn{2}{|l|}{ Size1 } & \multicolumn{2}{|l|}{ Size 2} \\
\hline \multirow[t]{2}{*}{ CONSTANT } & 0.0101 & $* * *$ & 0.0122 & $* * *$ & 0.0051 & $* * *$ \\
\hline & $(0.0009)$ & & $(0.0031)$ & & $(0.0010)$ & \\
\hline \multirow[t]{2}{*}{ Efficiency(-1) } & -0.0024 & & 0.0009 & & -0.0349 & $* * *$ \\
\hline & $(0.0039)$ & & $(0.0031)$ & & $(0.0065)$ & \\
\hline \multirow[t]{2}{*}{ Efficiency(-2) } & 0.0017 & & -0.0246 & & 0.0059 & \\
\hline & $(0.0038)$ & & $(0.0135)$ & & $(0.0064)$ & \\
\hline \multirow[t]{2}{*}{ Efficiency(-3) } & -0.0560 & $* * *$ & 0.0003 & & -0.0069 & \\
\hline & $(0.0038)$ & & $(0.0119)$ & & $(0.0064)$ & \\
\hline \multirow[t]{2}{*}{ Efficiency(-4) } & -0.0019 & & 0.0006 & & -0.0063 & \\
\hline & $(0.0043)$ & & $(0.0129)$ & & $(0.0658)$ & \\
\hline \multirow[t]{2}{*}{ Sum of Coefficients } & -0.0586 & & -0.0228 & & -0.0422 & \\
\hline & $(0.0079)$ & & $(0.0224)$ & & $(0.0667)$ & \\
\hline \multirow[t]{2}{*}{ NPL(-1) } & 0.7507 & $* * *$ & 0.5592 & $* * *$ & 0.3395 & \\
\hline & $(0.2034)$ & & $(0.0314)$ & & $(0.0634)$ & \\
\hline \multirow[t]{2}{*}{ NPL(-2) } & -0.0158 & $* * *$ & 0.0261 & $* * *$ & 0.0019 & \\
\hline & $(0.0018)$ & & $(0.0033)$ & & $(0.0068)$ & \\
\hline \multirow[t]{2}{*}{ NPL(-3) } & 0.0006 & $* * *$ & 0.0033 & $* * *$ & 0.0097 & \\
\hline & $(0.0001)$ & & $(0.0014)$ & & $(0.0013)$ & \\
\hline \multirow[t]{2}{*}{ NPL(-4) } & 0.0186 & & -0.0040 & $* * *$ & -0.0232 & \\
\hline & $(0.1293)$ & & $(0.0005)$ & & $(0.0032)$ & \\
\hline \multirow[t]{2}{*}{ Sum of Coefficients } & 0.7540 & & 0.5846 & & 0.3278 & \\
\hline & $(0.2411)$ & & $(0.0316)$ & & $(0.0639)$ & \\
\hline $\mathrm{F}$ & 14.5283 & & 4.082 & & 15.7602 & \\
\hline $\begin{array}{l}\text { Null Hypothesis: Efficiency } \\
\text { does not cause NPL }\end{array}$ & REJECT & & REJECT & & REJECT & \\
\hline P Value & $<1 \%$ & & $<1 \%$ & & $<1 \%$ & \\
\hline Observations & 74,305 & & 16,181 & & 36,223 & \\
\hline
\end{tabular}

*** Significant at $1 \%$

* Significant at 5\%

* Significant at 10\% 
Table 5.4: Granger Causality: Efficiency scores above average that does not cause NPL/LOAN ${ }^{77}$

Period 1985-2005

\begin{tabular}{|c|c|c|c|c|c|c|}
\hline \multirow[b]{2}{*}{ Variable } & \multicolumn{6}{|c|}{ Dependent Variable: NPL } \\
\hline & \multicolumn{2}{|l|}{ Panel } & \multicolumn{2}{|l|}{ Size 1} & \multicolumn{2}{|l|}{ Size 2} \\
\hline \multirow[t]{2}{*}{ CONSTANT } & 0.0051 & & 0.0149 & $* * *$ & 0.0262 & $* * *$ \\
\hline & $(0.0026)$ & & $(0.0050)$ & & $(0.0014)$ & \\
\hline \multirow[t]{2}{*}{ Efficiency(-1) } & -0.0016 & & 0.0137 & & 0.1292 & $* * *$ \\
\hline & $(0.0054)$ & & $(0.0149)$ & & $(0.0096)$ & \\
\hline \multirow[t]{2}{*}{ Efficiency(-2) } & 0.006 & & -0.0810 & $* * *$ & 0.0124 & \\
\hline & $(0.0060)$ & & $(0.0148)$ & & $(0.0102)$ & \\
\hline \multirow[t]{2}{*}{ Efficiency(-3) } & 0.0151 & $* * *$ & -0.0101 & & -0.0757 & $* * *$ \\
\hline & $(0.0059)$ & & $(0.0149)$ & & $(0.0101)$ & \\
\hline \multirow[t]{2}{*}{ Efficiency(-4) } & 0.0059 & & 0.0099 & & 0.1159 & $* * *$ \\
\hline & $(0.0054)$ & & $(0.0152)$ & & $(0.0101)$ & \\
\hline \multirow[t]{2}{*}{ Sum of Coefficients } & 0.0254 & & -0.0675 & & 0.1818 & \\
\hline & $(0.0114)$ & & $(0.0299)$ & & $(0.0200)$ & \\
\hline \multirow[t]{2}{*}{ NPL(-1) } & 0.2312 & $* * *$ & 0.3041 & $* * *$ & 0.2192 & \\
\hline & $(0.1083)$ & & $(0.0853)$ & & $(0.0228)$ & \\
\hline \multirow[t]{2}{*}{ NPL(-2) } & 0.0131 & $* * *$ & 0.0189 & & 0.0039 & \\
\hline & $(0.0020)$ & & $(0.0125)$ & & $(0.0004)$ & \\
\hline \multirow[t]{2}{*}{ NPL(-3) } & 0.0281 & $* * *$ & 0.0084 & $* * *$ & 0.0074 & \\
\hline & $(0.0079)$ & & $(0.0012)$ & & $(0.0020)$ & \\
\hline \multirow[t]{2}{*}{ NPL(-4) } & -0.0048 & $* * *$ & -0.0295 & $* * *$ & -0.0293 & \\
\hline & $(0.0014)$ & & $(0.0039)$ & & $(0.0086)$ & \\
\hline \multirow[t]{2}{*}{ Sum of Coefficients } & 0.2676 & & 0.3019 & & 0.2012 & \\
\hline & $(0.1086)$ & & $(0.0863)$ & & $(0.0244)$ & \\
\hline $\mathrm{F}$ & 22.2221 & & 15.7337 & & 14.2604 & \\
\hline $\begin{array}{l}\text { Null Hypothesis: Efficiency } \\
\text { does not cause NPL }\end{array}$ & REJECT & & REJECT & & REJECT & \\
\hline P Value & $<1 \%$ & & $<1 \%$ & & $<1 \%$ & \\
\hline Observations & 25,473 & & 5,103 & & 10,647 & \\
\hline
\end{tabular}

$* * *$ Significant at $1 \%$

* Significant at $5 \%$

* Significant at $10 \%$

${ }^{77}$ As we explained in the third section we follow DeYoung and Berger (1997) methodology and considered banks that showed DEA scores above the average. We control for year dummies as we explained in 5.6. Standard errors in parenthesis. 
Period 1985-1994

\begin{tabular}{|c|c|c|c|c|c|c|}
\hline \multirow[b]{2}{*}{ Variable } & \multicolumn{6}{|c|}{ Dependent Variable: NPL } \\
\hline & \multicolumn{2}{|l|}{ Panel } & \multicolumn{2}{|l|}{ Size1 } & \multicolumn{2}{|l|}{ Size 2} \\
\hline \multirow[t]{2}{*}{ CONSTANT } & 0.0227 & & 0.0078 & & 0.0443 & $* * *$ \\
\hline & $(0.0130)$ & & $(0.0072)$ & & $(0.0014)$ & \\
\hline \multirow[t]{2}{*}{ Efficiency(-1) } & 0.2627 & $* * *$ & 0.1561 & $* * *$ & 0.9054 & $* * *$ \\
\hline & $(0.0385)$ & & $(0.0230)$ & & $(0.0380)$ & \\
\hline \multirow[t]{2}{*}{ Efficiency(-2) } & 0.0946 & $* * *$ & 0.0514 & $* * *$ & -0.2299 & $* * *$ \\
\hline & $(0.0387)$ & & $(0.0220)$ & & $(0.0507)$ & \\
\hline \multirow[t]{2}{*}{ Efficiency(-3) } & 0.0672 & & -0.0094 & & -0.3955 & $* * *$ \\
\hline & $(0.0387)$ & & $(0.0225)$ & & $(0.0516)$ & \\
\hline \multirow[t]{2}{*}{ Efficiency(-4) } & 0.0241 & & 0.5209 & $* * *$ & 0.4502 & $* * *$ \\
\hline & $(0.0405)$ & & $(0.0228)$ & & $(0.0395)$ & \\
\hline \multirow[t]{2}{*}{ Sum of Coefficients } & 0.4486 & & 0.7190 & & 0.7302 & \\
\hline & $(0.0782)$ & & $(0.0452)$ & & $(0.0908)$ & \\
\hline \multirow[t]{2}{*}{ NPL(-1) } & 0.7865 & $* * *$ & 0.5852 & $* * *$ & 0.4849 & \\
\hline & $(0.1140)$ & & $(0.1135)$ & & $(0.1078)$ & \\
\hline \multirow[t]{2}{*}{ NPL(-2) } & 0.0142 & $* * *$ & 0.0151 & $* * *$ & 0.0155 & \\
\hline & $(0.0018)$ & & $(0.0016)$ & & $(0.0053)$ & \\
\hline \multirow[t]{2}{*}{ NPL(-3) } & 0.0143 & $* * *$ & -0.0113 & $* * *$ & 0.0216 & \\
\hline & $(0.0014)$ & & $(0.0015)$ & & $(0.0046)$ & \\
\hline \multirow[t]{2}{*}{ NPL(-4) } & -0.0075 & $* * *$ & 0.0200 & $* * *$ & 0.0136 & \\
\hline & $(0.0011)$ & & $(0.0051)$ & & $(0.0025)$ & \\
\hline \multirow[t]{2}{*}{ Sum of Coefficients } & 0.8075 & & 0.6089 & & 0.5355 & \\
\hline & $(0.1140)$ & & $(0.1137)$ & & $(0.1081)$ & \\
\hline $\mathrm{F}$ & 4.3829 & & 23.3377 & & 18.9039 & \\
\hline $\begin{array}{l}\text { Null Hypothesis: Efficiency } \\
\text { does not cause NPL }\end{array}$ & REJECT & & REJECT & & REJECT & \\
\hline P Value & $<1 \%$ & & $<1 \%$ & & $<1 \%$ & \\
\hline Observations & 21,520 & & 6,240 & & 10,200 & \\
\hline
\end{tabular}

*** Significant at $1 \%$

* Significant at 5\%

* Significant at 10\% 
Period 1995-2005

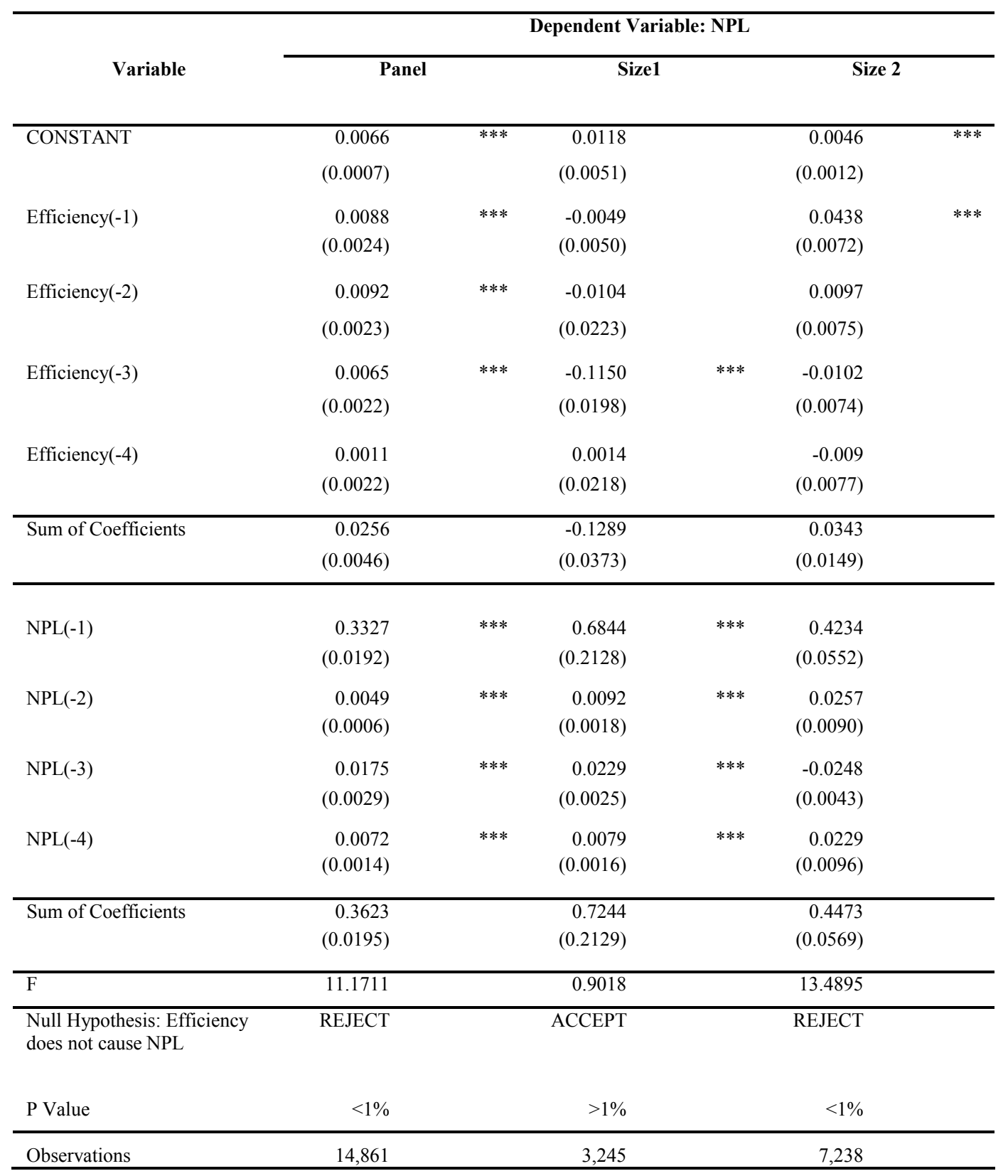

*** Significant at $1 \%$

* Significant at 5\%

* Significant at 10\% 

Period 1985-2005

\begin{tabular}{|c|c|c|c|c|c|c|}
\hline \multirow[b]{2}{*}{ Variable } & \multicolumn{6}{|c|}{ Dependent Variable: NPL } \\
\hline & \multicolumn{2}{|l|}{ Panel } & \multicolumn{2}{|l|}{ Size 1} & \multicolumn{2}{|l|}{ Size 2} \\
\hline \multirow[t]{2}{*}{ CONSTANT } & 0.0102 & $* * *$ & 0.0119 & $* * *$ & 0.0059 & $* * *$ \\
\hline & $(0.0004)$ & & $(0.0010)$ & & $(0.0005)$ & \\
\hline \multirow[t]{2}{*}{ CAP(-1) } & 0.0003 & $* * *$ & -0.064 & $* * *$ & 0.0006 & $* * *$ \\
\hline & $(0.0001)$ & & $(0.0318)$ & & $(0.0003)$ & \\
\hline \multirow[t]{2}{*}{ CAP(-2) } & -0.0025 & & 0.0003 & & 0.0003 & \\
\hline & $(0.0013)$ & & $(0.0469)$ & & $(0.0270)$ & \\
\hline \multirow[t]{2}{*}{ CAP(-3) } & -0.0064 & $* * *$ & -0.0259 & & -0.0099 & \\
\hline & $(0.0017)$ & & $(0.0298)$ & & $(0.0365)$ & \\
\hline \multirow[t]{2}{*}{ CAP(-4) } & -0.0003 & $* * *$ & 0.0061 & & -0.3070 & $* * *$ \\
\hline & $(0.0001)$ & & $(0.0203)$ & & $(0.0229)$ & \\
\hline \multirow[t]{2}{*}{ Sum of Coefficients } & -0.0089 & & -0.0835 & & -0.3160 & \\
\hline & $(0.0021)$ & & $(0.0672)$ & & $(0.0508)$ & \\
\hline \multirow[t]{2}{*}{ NPL(-1) } & 0.5718 & $* * *$ & 0.5677 & $* * *$ & 0.6693 & \\
\hline & $(0.2980)$ & & $(0.0199)$ & & $(0.0696)$ & \\
\hline \multirow[t]{2}{*}{ NPL(-2) } & 0.0087 & $* * *$ & 0.0276 & $* * *$ & -0.0196 & \\
\hline & $(0.0016)$ & & $(0.0031)$ & & $(0.0029)$ & \\
\hline \multirow[t]{2}{*}{ NPL(-3) } & -0.0160 & $* * *$ & -0.0186 & & 0.0027 & \\
\hline & $(0.0022)$ & & $(0.0120)$ & & $(0.0004)$ & \\
\hline \multirow[t]{2}{*}{ NPL(-4) } & 0.0157 & $* * *$ & 0.0228 & $* * *$ & 0.0139 & \\
\hline & $(0.0049)$ & & $(0.0044)$ & & $(0.0020)$ & \\
\hline \multirow[t]{2}{*}{ Sum of Coefficients } & 0.5801 & & 0.5995 & & 0.6663 & \\
\hline & $(0.2980)$ & & $(0.0239)$ & & $(0.0697)$ & \\
\hline $\mathrm{F}$ & 16.0859 & & 4.8012 & & 11.9109 & \\
\hline $\begin{array}{l}\text { Null Hypothesis: CAP does } \\
\text { not cause NPL }\end{array}$ & REJECT & & REJECT & & REJECT & \\
\hline P Value & $<1 \%$ & & $<1 \%$ & & $<1 \%$ & \\
\hline Observations & 127,407 & & 27,321 & & 53,424 & \\
\hline
\end{tabular}

*** Significant at $1 \%$

* Significant at $5 \%$

* Significant at $10 \%$

${ }^{78}$ DeYoung and Berger (1997) considered banks that in 1985 showed ratio of capital - assets below the average (thinly capitalized banks). We did not eliminated what they called thinly capitalized banks. We control here for Year dummies. Standard errors in parenthesis. 
Period 1985-1994

\begin{tabular}{|c|c|c|c|c|c|c|}
\hline \multirow[b]{2}{*}{ Variable } & \multicolumn{6}{|c|}{ Dependent Variable: NPL } \\
\hline & \multicolumn{2}{|l|}{ Panel } & \multicolumn{2}{|l|}{ Size1 } & \multicolumn{2}{|l|}{ Size 2} \\
\hline CONSTANT & 0.0112 & $* * *$ & 0.023 & $* * *$ & 0.0209 & $* * *$ \\
\hline & $(0.0005)$ & & $(0.0016)$ & & $(0.0007)$ & \\
\hline CAP(-1) & -0.0021 & $* * *$ & -0.008 & $* * *$ & -0.1753 & $* * *$ \\
\hline & $(0.0018)$ & & $(0.0002)$ & & $(0.0274)$ & \\
\hline \multirow[t]{2}{*}{ CAP(-2) } & -0.0070 & $* * *$ & -0.0109 & & 0.0053 & $* * *$ \\
\hline & $(0.0021)$ & & $(0.0088)$ & & $(0.0420)$ & \\
\hline \multirow[t]{2}{*}{ CAP(-3) } & -0.0030 & & -0.0113 & & 0.0405 & \\
\hline & $(0.0019)$ & & $(0.0072)$ & & $(0.0461)$ & \\
\hline \multirow[t]{2}{*}{ CAP(-4) } & 0.0015 & & 0.0126 & & 0.0057 & \\
\hline & $(0.0023)$ & & $(0.0067)$ & & $(0.0286)$ & \\
\hline \multirow[t]{2}{*}{ Sum of Coefficients } & -0.0106 & & -0.0176 & & -0.1238 & \\
\hline & $(0.0041)$ & & $(0.0132)$ & & $(0.0739)$ & \\
\hline \multirow[t]{2}{*}{ NPL(-1) } & 0.3108 & & 0.4837 & $* * *$ & 0.3709 & \\
\hline & $(0.2469)$ & & $(0.0952)$ & & $(0.0821)$ & \\
\hline \multirow[t]{2}{*}{ NPL(-2) } & 0.0212 & $* * *$ & 0.0009 & $* * *$ & 0.0193 & \\
\hline & $(0.0051)$ & & 0.0002 & & $(0.0655)$ & \\
\hline \multirow[t]{2}{*}{ NPL(-3) } & -0.0073 & $* * *$ & -0.0052 & $* * *$ & -0.0162 & \\
\hline & $(0.0011)$ & & 0.0011 & & $(0.0023)$ & \\
\hline \multirow[t]{2}{*}{ NPL(-4) } & 0.0228 & & 0.0156 & & 0.0167 & \\
\hline & $(0.0392)$ & & $(0.0092)$ & & $(0.0026)$ & \\
\hline \multirow[t]{2}{*}{ Sum of Coefficients } & 0.3476 & & 0.4949 & & 0.3908 & \\
\hline & $(0.2501)$ & & $(0.0957)$ & & $(0.1050)$ & \\
\hline $\mathrm{F}$ & 80.6231 & & 49.6124 & & 55.0184 & \\
\hline $\begin{array}{l}\text { Null Hypothesis: CAP does } \\
\text { not cause NPL }\end{array}$ & REJECT & & REJECT & & REJECT & \\
\hline P Value & $<1 \%$ & & $<1 \%$ & & $<1 \%$ & \\
\hline Observations & 107,620 & & 31,200 & & 51,000 & \\
\hline
\end{tabular}

*** Significant at $1 \%$

* Significant at 5\%

* Significant at 10\% 
Period 1995-2005

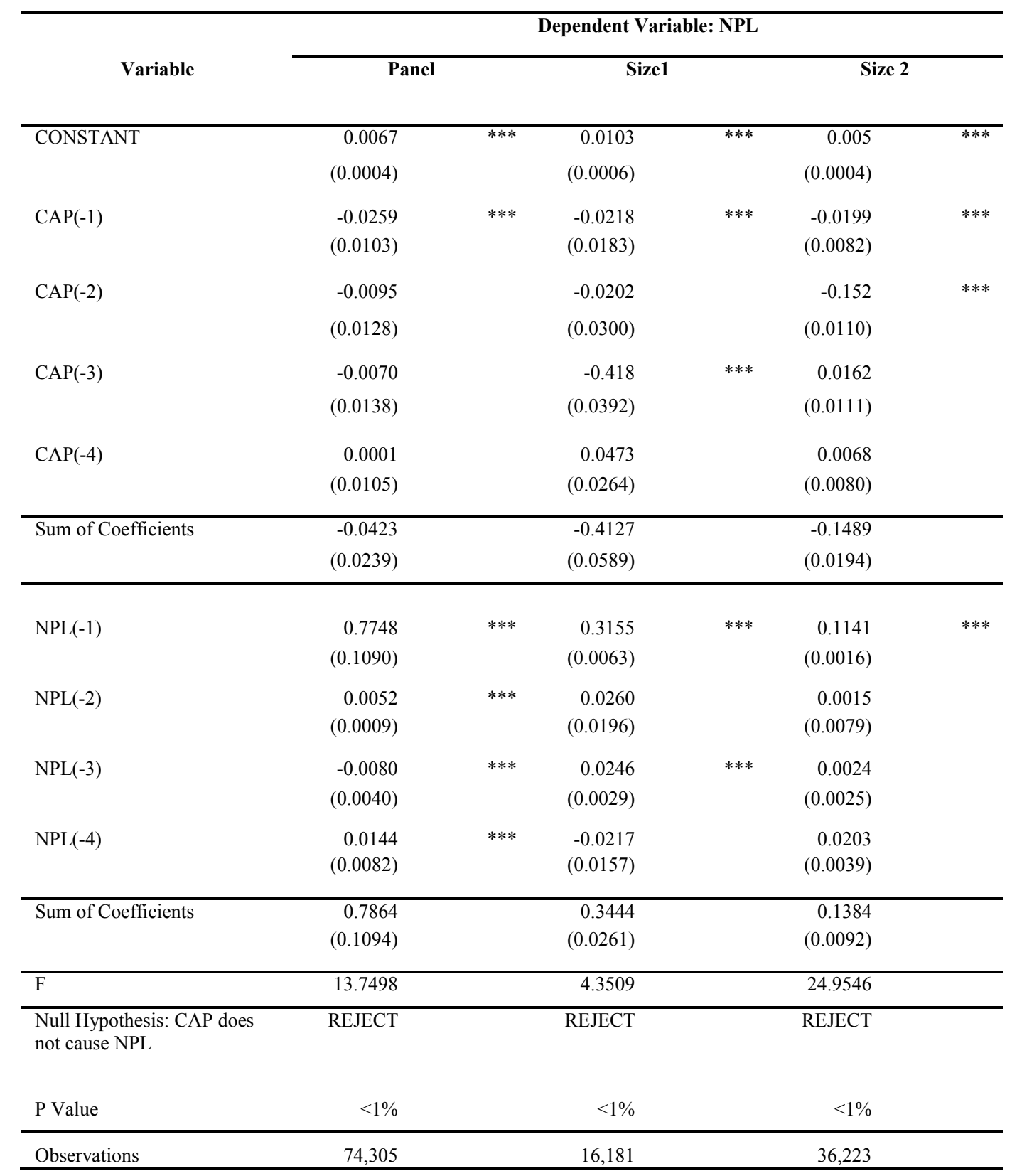

*** Significant at $1 \%$

* Significant at 5\%

* Significant at 10\% 
Table 5.6: Summary of the Four Hypotheses by size and period of time

\begin{tabular}{lccc}
\hline & & Period & \\
\cline { 2 - 4 } Size & 1985-2005 & 1985-1994 & 1995-2005 \\
\hline \multirow{4}{*}{ Size 1 } & Accepts Bad & Accepts Bad & Accepts Bad \\
& Management, Bad & Management, Bad & Management, Bad \\
& Luck, Skimping and & Luck, Skimping and & Luck and Moral \\
& Moral Hazard. & Moral Hazard & Hazard \\
& & & \\
Size 2 & Accepts Bad & Accepts Bad & Accepts Bad \\
& Management, Bad & Management, Bad & Management, Bad \\
& Luck, Skimping and & Luck, Skimping and & Luck, Skimping and \\
& Moral Hazard. & Moral Hazard & Moral Hazard \\
& & & \\
Total System & Accepts Bad & Accepts Bad & Accepts Bad \\
& Management, Bad & Management, Bad & Management, Bad \\
& Luck, Skimping and & Luck, Skimping and & Luck, Skimping and \\
& Moral Hazard. & Moral Hazard & Moral Hazard \\
& & & \\
& & & \\
& & &
\end{tabular}


Table 5.7: Definitions and descriptive statistics for the variables employed in Granger Causality Test (for the whole period 1985-2005).

\begin{tabular}{llcc}
\hline Variables & Explanation & Mean & Std. dev \\
\hline Efficiency & Cost Efficiency & 0.15 & 0.03 \\
NPL & $\begin{array}{l}\text { Shares of Nonperforming } \\
\text { Loans }\end{array}$ & 0.02 & 0.01 \\
CAP & Ratio of Capital by Assets & 0.03 & 0.01 \\
\hline
\end{tabular}




\section{References}

Adriaan Bloem and Cornelis N. Gorter. "The Treatment of Nonperforming loans in Macroeconomic Statistics”. International Monetary Fund, 2001

Aigner, D. J., T. Amemiya and D. J. Poirier. "On the estimation of Production Frontiers: Maximum Likelihood Estimation of Parameters of a Discontinuous Density Function”, International Economic Review 17:2 (June), 377-96, 1976

Aigner, D.J., and K.Lovell, and P. Schdmit, eds. "Formulation and Estimation of Stochastic Frontier Production Function Models", Journal of Econometrics 6:1 (July), 21-37, 1977

Akhigbe, Aigbe, and Jeff Madura. "Why do contagion effects vary among bank failures?", Journal of Banking \& Finance Vol. 25, No. 4, April 2001.

Altman Edward I. "Financial Ratios, Discriminant Analysis and the Prediction of Corporate Bankruptcy”. The journal of Finance, Vol23, Issue 4, 589-609,1968

Amel, Dean. "State Laws Affecting Commercial Bank Branching, Multibank Holding Company Expansion, and Interstate Banking”. Board of Governors of the Federal Reserve System. 1993

Avery, Robert B. and Katherine A. Samolyk "Bank Consolidation and Small Business Lending: The Role of Community Banks.” Journal of Financial Services Research 25, 291-352, 2004

Barr Robert, Killgo Kory and Siems Thomas. "Evaluating the productive Efficiency and Performance of U.S. Commercial Banks”. Working Paper. Federal Reserve Bank of Dallas, 1999 
Berger and De Young. "Problem Loans and Cost Efficiency in Commercial Banks" Journal of banking and Finance, Col 21, 1997 pp 1-28, 1997

Berger A and Mester L.J.. "Inside the Black Box. What Explains Difference in the Efficiencies in Financial Institutions?” Journal of Banking and Finance 21, 895-947, 1997

Berger , Leusner and Mingo. "The efficiency of bank branches". Journal of Monetary Economics. 40(141-161). 1997

Berger, Allen N., Seth D. Bonime, Daniel M. Covitz, and Diana Hancock. "Why Are Bank Profits So Persistent? The Roles of Product Market Competition, Informational Opacity, and Regional/Macroeconomic Shocks?” Journal of Banking and Finance, v24(7), 12031235,2000

Berger A and Mester L.J. "Explaining the dramatic changes in performance of US banks: technological change, deregulation and dynamic changes in competition”. Journal of Financial Intermediation 12, 57-95, 2003

Bernanke, Ben S. and Alan S. Blinder . "The Federal Funds Rate and The Channels Of Monetary Transmission". American Economic Review, v82(4), 901-921, 1992

Calomiris, Charles W. and Carlos D. Ramirez. "The Political Economy of Bank Entry Restrictions: Theory and Evidence form the U.S. in the 1920s.” 2004.

Carrow, K. and G. Larsen. "Bank Branching Laws as Determinants of Industry Concentration." The Southern Business and Economics Journal, Vol. 22, No 1, 35-44, 1998.

Charnes, Cooper and Rhode. "Measuring the Efficiency of Decision Making Units" European Journal of Operations research 2(6) pp 429-44, 1978

Cheng, Mason and Higgins. "Does bank Efficiency change with the Business Cycle? The relationship between monetary policy, economic growth, and bank condition”. Mimeo. Emporia University, 2001 
Christiano, Lawrence J. and Lars Ljungqvist. "Money Does Granger-Cause Output In The Bivariate Money-output Relation". Journal of Monetary Economics, v22(2), 217-236, 1988

Cooper, W.W., Seiford, L.M. and Zhu, Joe . "Data envelopment analysis: History, Models and Interpretations”. Handbook on Data Envelopment Analysis, eds W.W. Cooper, L.M. Seiford and J. Zhu, Chapter 1, 1-39, Kluwer Academic Publishers, Boston, 2004

Demirguc-Kunt, Asli, "Deposit Institution Failures: A Review of the Empirical Literature", Federal Reserve Bank of Cleveland, Economic Review, Quarter 4, 1989

DeYoung Robert. "The Impact of Out-of-State Entry on the Cost Efficiency of Local Commercial Banks”. Journal of Economics and Business. v.50. Pages 191-203, 1998

DeYoung, Robert, Lawrence G. Goldberg, and Lawrence J. White, "Youth, adolescence and maturity of banks: Credit availability to small business in an era of banking consolidation”, Working Paper, New York University. 1997

Dick, Astrid A. "Nationwide Branching and its Impact on Market Structure, Quality and Bank Performance.” Journal of Business, 2003.

Ding Lu, Shandre M. Thangavelu and Qing $\mathrm{Hu}$ "The Link between Bank Behavior and Nonperforming Loans in China" National University of Singapore, Department of Economics, 2001

Ennis H. "Some Recent Trends in Commercial Banking”. Federal Reserve Bank of Richmond. Economic Quarterly. Vol. 90/2, Spring 2004

Ennis H. "On the Size Distribution of Banks". FRB of Richmond. Economic Quarterly, Fall 2001: Vol. 87, No. 4.

Farrel M J. "The measurement of productive efficiency". Journal of the Royal Statistical Society. $120(3), 1957$.

Financial Institutions Reform, Recovery, and Enforcement Act of 1989 
Freeman, Donald G . "Did State Bank Branching Deregulation Produce Large Effects?" Economics Letters 73(5), May 2002: 383-89, 2002.

Friedman, Milton and Anna J. Schwartz . "Money And Business Cycles". Review of Economics and Statistics, v45(1), Part 2, 32-64, 1963.

Garret, Wagner and Wheelock. “A spatial analysis of State Banking Regulation”. WP Federal Reserve Bank of St. Louis, 2004:06.

Gilbert, Alton. "Nationwide Branch Banking and the Presence of Large Banks in Rural Areas." Federal Reserve Bank of St. Louis, May/June 2000.

Guillen, Jorge. "Relative Efficiency and its link to the nonperforming loans". West Virginia University, Working Paper. Presented at the Global Finance Conference, 2003.

Kane, E. “De Jure Interstate Banking: Why Only Now?” Journal of Money, Credit and Banking, Vol 28, No2, 141-161, 1996.

Keeton, William R., "Multi-office bank lending to small businesses: Some new Evidence", Federal Reserve Bank of Kansas City Economic Review 81, 63-75. 1995

Hansweck,G.A.. "Predicting Bank Failure". Research Paper in Banking and Financial Economics, Financial Studies Section, Division of Research and Statistics, Board of Governors of the Federal Reserve System, 1977

International Financial Statistics, 2005. International Monetary Fund (IMF).

Interstate Banking and Branching Efficiency Act of 1994-Conference Report (Senate September 13, 1994)

Jahera, John S., Jr. "FIRREA and the savings and loan industry: was there a wealth effect?" (Financial Institutions Reform, Recovery and Enforcement Act of 1989) Mid-Atlantic Journal of Business, December, 1995

Jayaratne, Jith and Philip E. Strahan. "The Finance-Growth Nexus: Evidence from Bank Branch Deregulation”. Quarterly Journal of Economics 111, 639-70, 1996. 
Jondrow, J., C.A.K. Lovell, I.S. Materov, and P. Schmidt. "On the Estimation of Technical Inefficiency in the Stochastic Frontier production Function Model". Journal of Econometrics. 19:2/3 (August), 233-38, 1982

Judd, K. “Credible Spatial Preemption.” Rand Journal of Economics, 16: 153 - 166, 1985.

Kaufman George. "Bank failures, systemic risk, and bank regulation". Working Papers, No. 01. Federal Reserve Bank of Chicago, 1996.

Kroszner and Strahan. "What drives Deregulation? Economics and Politics of the Relaxation of Bank Branching Restrictions”. Quarterly Journal of Economics, 114(4), 1999.

Kumbhakar Subal and Lovell Knox. "Stochastic Frontier Analysis". Cambridge University Press. 2000

Madura Jeff, "The Impact of the Financial Institutions Reform, Recovery and Enforcement Act on The Risk of Savings Institutions" Volume 35, No. 3, pp. 145-168. Financial review. 2000

Martin, D. "Early Warning of Bank Failure: A Logit Regression Approach”. Journal of Banking and Finace, 1, 249-276, 1977

Meeusen, W., and J. van den Broeck. "Efficiency Estimation from Cobb-Douglas Production Functions with Composed Error”, International Economic Review 18:2 (June) 435-44, 1977

Mishkin, Frederic and Eakins, Stanley. Financial Markets and Institutions. $3^{\text {rd }}$ ed., Addison Wesley Longman, Inc, 1999.

Moore, Geoffrey. "The Quality of Credit in Booms and Depressions". Journal of Finance, May, 1956

Mulloy Patric. "The Riegle-Neal Interstate Banking and Branching Efficiency Act of 1994: Responding To Global Competition.” Journal of Legislation, 1995. 
Pantalone, Platt. "Predicting Commercial Banks Failure Since Deregulation". New England Economic Review, July/August, 37-47, 1987.

Peterson, Mitchell A. and Raghuram G. Rajan. "Does Distance Still Matter? The Information Revolution in Samll Business Lending.” The Journal of Finance, Vol. LVII, No. 6, December 2002.

Prescott, E and M. Visscher. "Sequential Location among Firms with Foresight." Bell Journal of Economics, Vol. 8, No. 2 , pp. 378-393, 1977.

Rollinger, M. “Interstate Banking And Branching Under The Riegle-Neal Act Of 1994.” Harvard Journal on Legislation, Winter 1996.

Senzel, J. "The Mcfadden Act.” In Interstate Branch Banking Reform: Preserving the Policies Underlying, Boston University Law Review, 1992.

Shumway Tyler. "Forecasting Bankruptcy More Accurately: A Simple Hazard Model". The Journal of Business, Vol 74, Issue 1, 101-124, 2001

Sims, Christopher A. "Money, Income, and Causality". American Economic Review, v62(4), 540-552, 1972.

Strahan, Philip E. “The Real Effect of U.S. Banking Deregulation.” Federal Reserve Bank of St. Louis, July/August, 2003.

Stein, Berger, Miller, Petersen, Rajan and Berger "Does Function Follow Organizational Form?. Evidence from the Lending Practices of Large and Small Banks". Forthcoming in the Journal of Finance, 2004.

Tart, C. "Of the Banking Industry Under the Riegle-Neal Interstate Banking and Branching Efficiency Act of 1994: Is the Banking Industry Headed in the Right Direction?" In Wake Forest Law Review, 1995. 
Whalen, Gary, "A Proportional Moral Hazard Model of Bank failure: An Examination of Its Usefulness as an Early Warning Tool." Federal Reserve Bank of Cleveland, Quarter 1, 1991

Wilson, Paul W. and Wheelock. "Why Do Banks Disappear: The Determinants of US Bank Failure and Acquisitions”. Review of Economic and Statistics, February, 127-138, 2000

Wilson, Paul W. "FEAR: A Package for Frontier Efficiency Analysis with R". Unpublished working paper. Department of Economics, University of Texas at Austin, 2005. 